\title{
Developing a Framework to Understand Teachers' Self-efficacy in the Teaching of Writing
}

\author{
Barbara J. Wierzbicki
}

Follow this and additional works at: https://researchrepository.wvu.edu/etd

\section{Recommended Citation}

Wierzbicki, Barbara J., "Developing a Framework to Understand Teachers' Self-efficacy in the Teaching of Writing" (2018). Graduate Theses, Dissertations, and Problem Reports. 6947.

https://researchrepository.wvu.edu/etd/6947

This Dissertation is protected by copyright and/or related rights. It has been brought to you by the The Research Repository @ WVU with permission from the rights-holder(s). You are free to use this Dissertation in any way that is permitted by the copyright and related rights legislation that applies to your use. For other uses you must obtain permission from the rights-holder(s) directly, unless additional rights are indicated by a Creative Commons license in the record and/ or on the work itself. This Dissertation has been accepted for inclusion in WVU Graduate Theses, Dissertations, and Problem Reports collection by an authorized administrator of The Research Repository @ WVU.

For more information, please contact researchrepository@mail.wvu.edu. 


\title{
DEVELOPING A FRAMEWORK TO UNDERSTAND TEACHERS' SELF-
}

\section{EFFICACY IN THE TEACHING OF WRITING}

\author{
Barbara J. Wierzbicki \\ Dissertation submitted to the \\ College of Education and Human Services at West Virginia University \\ In partial fulfillment of the requirements for the degree of \\ Doctor of Education \\ in \\ Curriculum \& Instruction
}

\author{
Malayna Bernstein, Ph.D., Co-Chair \\ Sharon Hayes, Ph.D., Co-Chair \\ Audra Slocum, Ph.D. \\ Allison Swan Dagen, Ph.D. \\ Cynthia Bolton-Gary, Ph.D. \\ Department of Curriculum and Instruction/Literacy Studies \\ Morgantown, West Virginia \\ 2018
}

Keywords: self-efficacy, writing self-efficacy, teaching self-efficacy, teaching writing self-efficacy 


\section{Abstract \\ Developing a Framework to Understand Teachers' Self-Efficacy in the Teaching of Writing}

\section{Barbara J. Wierzbicki}

The purpose of this study was to explore the ways in which the domain specific selfefficacies manifest themselves in the teaching of writing. A teachers' sense of efficacy is a multidimensional construct and is a significant construct in how teachers' view themselves as writers and teachers of writing. This study explored how five elementary classroom teachers viewed these domain specific self-efficacies and the ways in which the various sources of efficacy influenced their self-efficacy as writers and teachers of writing. The researcher collected and analyzed domain specific self-efficacy scales and individual interviews to capture the experiences of these teachers. There was variability across and within the domain specific self-efficacy scales. The most salient source of efficacy as a writer and teacher of writing that emerged was physiological arousals. 


\section{Dedication}

To my husband, Bill, for your unconditional faith and love. You are my rock and I will forever be grateful for your support in pursuing by life-long dream. 


\section{Acknowledgements}

I would first like to thank the members of my dissertation committee for their time and support throughout my dissertation journey. I am indebted to Dr. Malayna Bernstein and Dr. Sharon Hayes who served as co-chairs of my committee. You both have set an example of excellence as a researcher, mentor, instructor, and role model. Thank you for challenging me to go beyond my comfort zone. I would like to thank Dr. Audra Slocum for providing guidance and thoughtful feedback and Dr. Allison Swan Dagen for serving as a member of my committee during the difficult transition to a new research focus. I would also like to thank Dr. Cynthia Bolton-Gary for bringing me into the world of self-efficacy. I will forever be grateful to all these strong women.

I would especially like to thank my family for the love, support, and constant encouragement I have gotten over the years. Particularly, I would like to thank my husband, Bill and my sisters, Debbie, Lisa, and Patti. You are all the salt of the earth, and I undoubtedly could not have done this without you. A special thank you to my nephew, Matthew, for always reminding me to practice what I preach.

I want to extend a heartfelt thank you to my friends who I met along the way. Each of you were brought into my life for a special reason and I have learned so much from you. Thank you for the memories, the conversations, the laughter and tears.

I would like to acknowledge all the students from the Five-Year Teacher Education program who readily provided friendship, support, and words of encouragement. I am blessed to have worked with so many fabulous pre-service teachers.

Most importantly, I want to express my gratitude to the teachers who participated in this study. I sincerely appreciate the time you took from your busy schedules to share your experiences as a writer and teacher of writing.

Lastly, I would be remiss if I did not mention my little Henry. Thank you for listening to countless hours of me talking through my study. You were a gracious listener and always gave me the best feedback possible - your enduring smile and infectious laugher. I will forever be grateful! 


\section{Table of Contents}

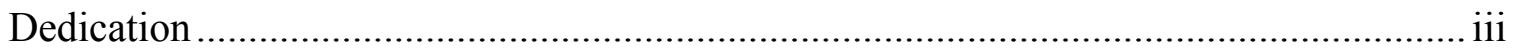

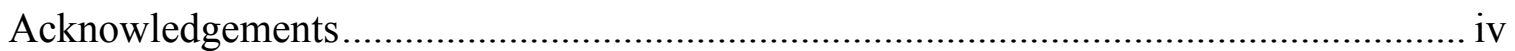

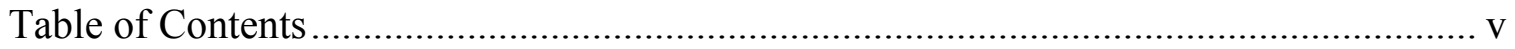

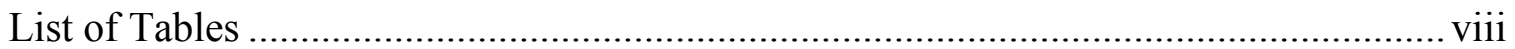

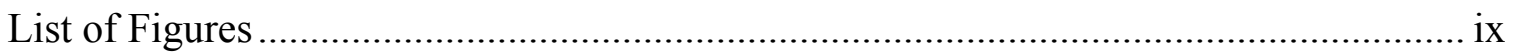

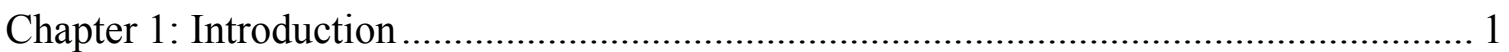

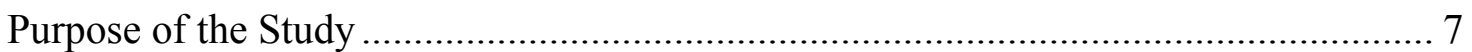

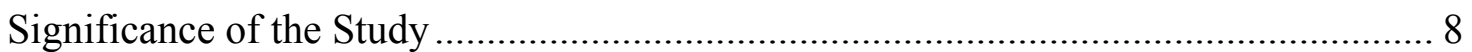

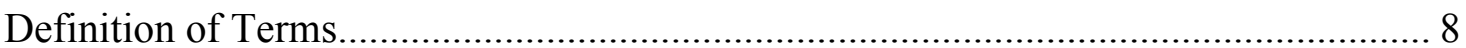

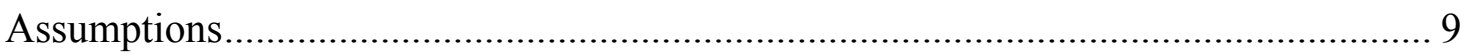

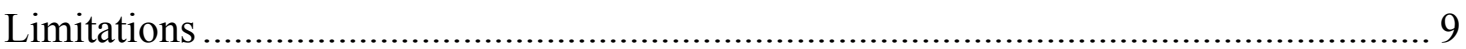

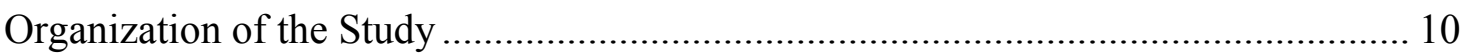

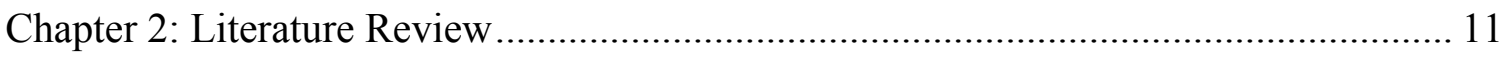

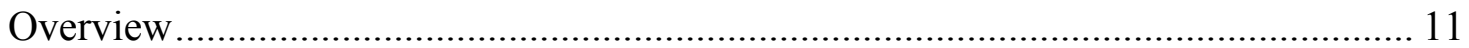

Theoretical Underpinnings and Conceptual Framework ......................................... 11

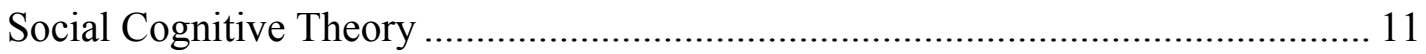

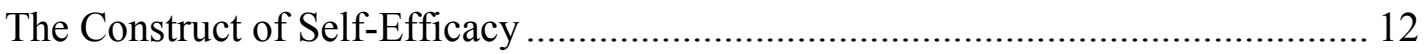

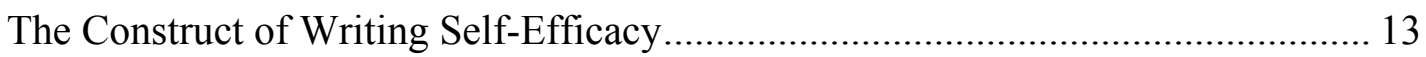

The Construct of Teacher Self-Efficacy ............................................................... 15

The Construct of Teacher Efficacy in the Context of Writing Instruction ................ 18

Previous Studies Exploring Writing Self-Efficacy and Teaching of Writing Self-

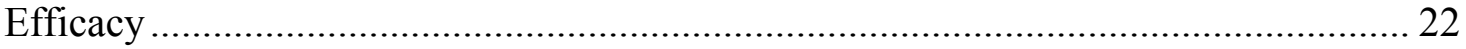

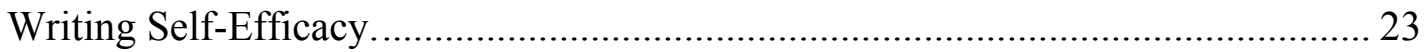

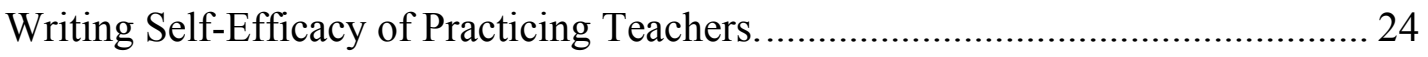

Teacher Self-Efficacy in the Context of Writing Instruction................................... 25

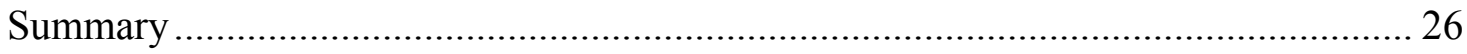

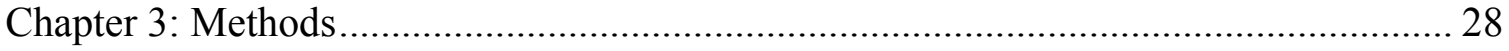

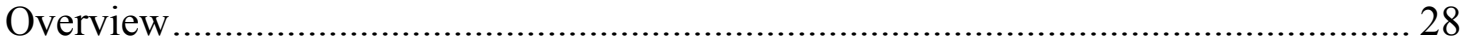

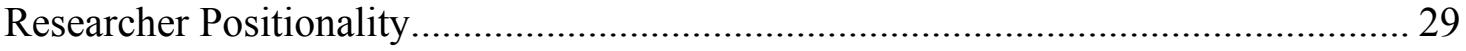

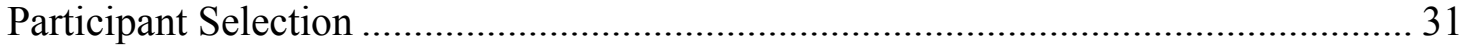

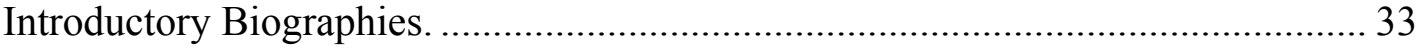

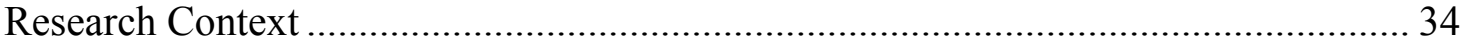

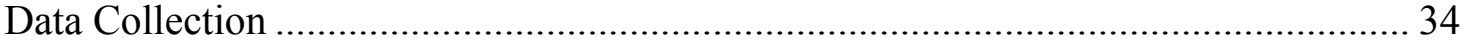


Data Source: Background Information Questionnaire......................................... 34

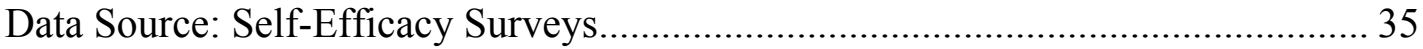

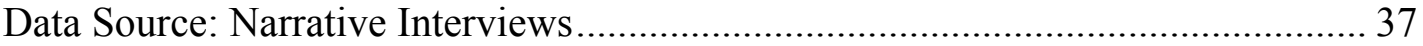

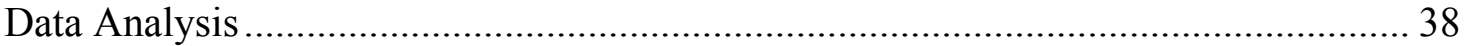

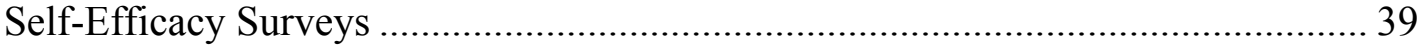

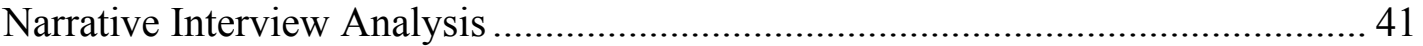

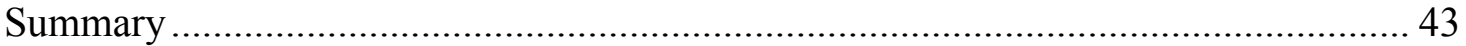

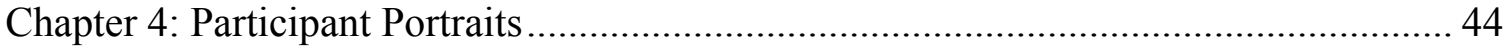

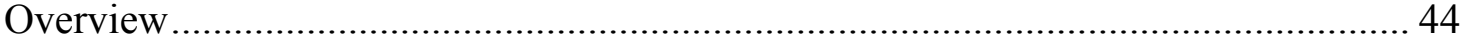

Domain Specific Self-Efficacy Scale Results ...................................................... 44

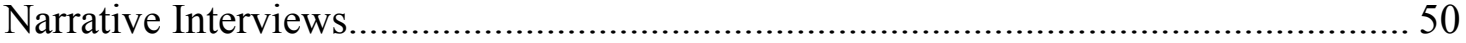

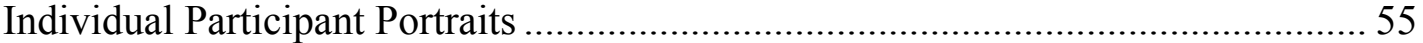

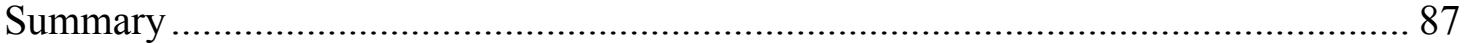

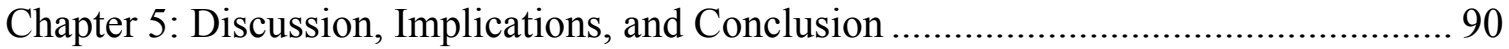

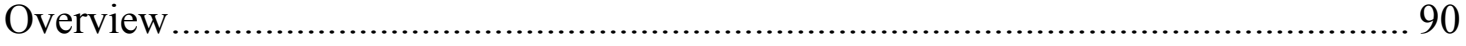

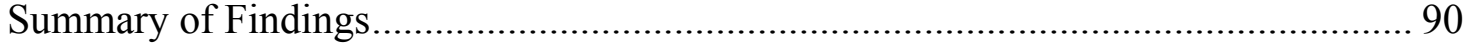

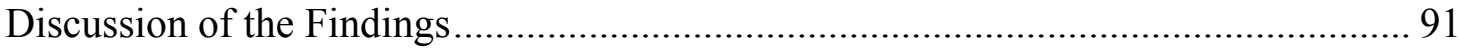

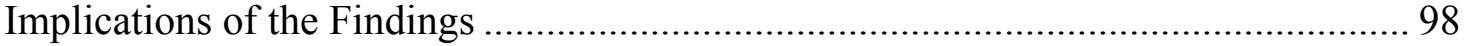

Implications for Teacher Preparation Programs …............................................. 98

Implications for Professional Development...................................................... 100

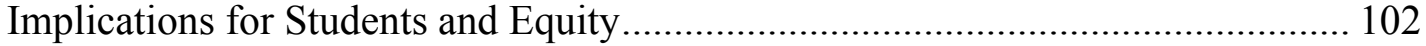

Recommendations for Future Research ........................................................... 104

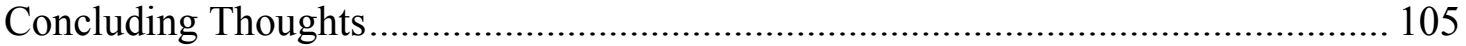

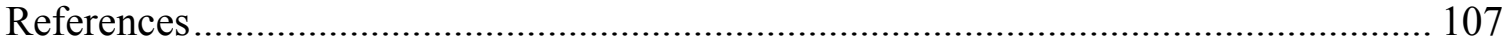

APPENDIX A - INFORMED CONSENT FORM ................................................... 118

APPENDIX B - BACKGROUND INFORMATION ............................................... 122

APPENDIX C - NEW GENERAL SELF-EFFICACY SCALE .................................. 124

APPENDIX D - SELF-EFFICACY FOR WRITING SCALE ................................... 126

APPENDIX E - TEACHERS' SENSE OF EFFICACY SCALE ................................. 128

APPENDIX F - TEACHER EFFICACY SCALE FOR WRITING ............................ 131

APPENDIX G - NARRATIVE INTERVIEW PROTOCOL .................................... 133

APPENDIX H - DESCRIPTIVE STATISTICS CALCULATIONS ......................... 135

APPENDIX I - SOURCES OF SELF-EFFICACY AS A WRITER ............................. 138

APPENDIX J - SOURCES OF SELF-EFFICACY AS A TEACHER OF WRITING . 142 
APPENDIX K - CODED SOURCES OF EFFICACY INFORMATION……………... 145 


\section{List of Tables}

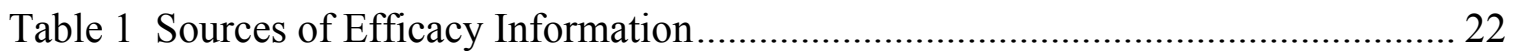

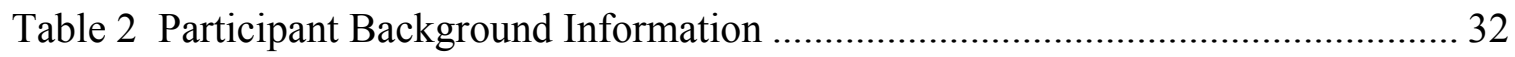

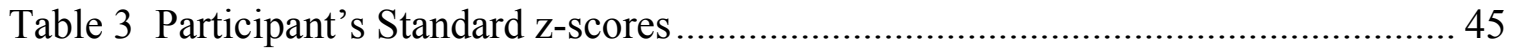

Table 4 New General Self-Efficacy Scale Scores.................................................... 46

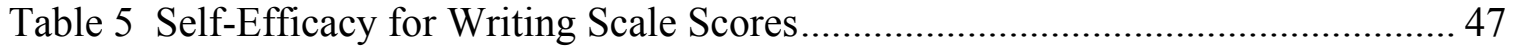

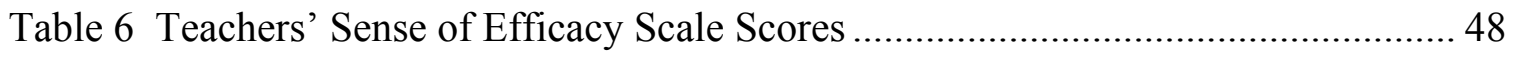

Table 7 Teacher Efficacy Scale for Writing Scores.................................................... 49

Table 8 Summary of Individual Standard (z-scores) Overall Scores ............................ 56 


\section{List of Figures}

Figure 1. Integrated Model of Teacher Self-Efficacy Beliefs...................................... 17

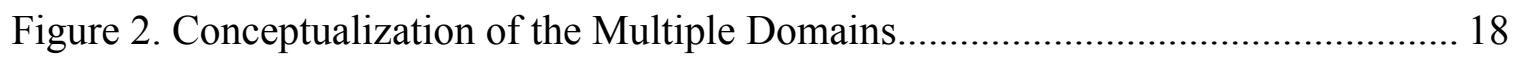

Figure 3. Proposed Integrated Model of Teacher Self-Efficacy Beliefs in the Domain of

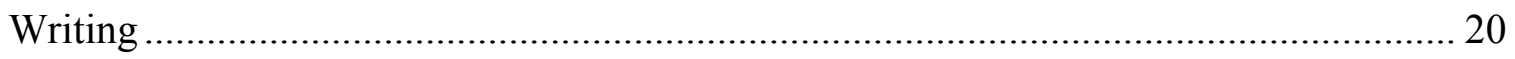

Figure 4. Composite Breakdown of all Participant's Sources of Self-Efficacy .............. 51

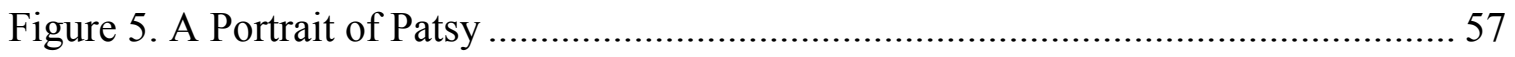

Figure 6. Patsy's Sources of Efficacy Information .................................................. 58

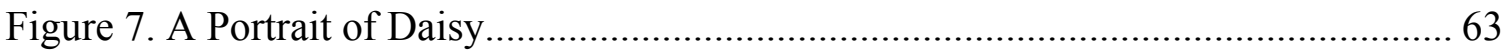

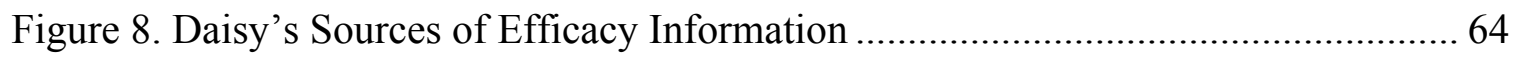

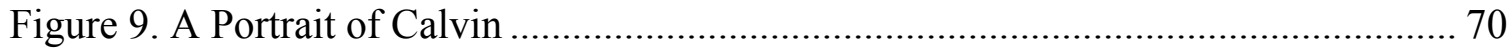

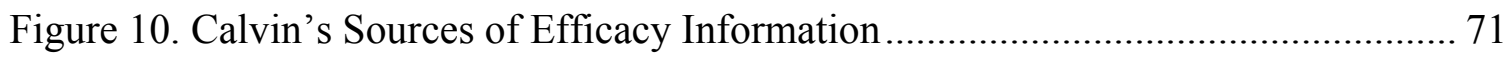

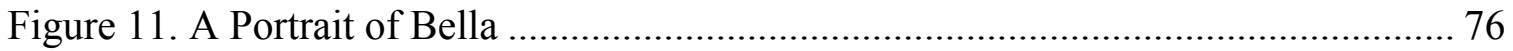

Figure 12. Bella's Sources of Efficacy Information ............................................... 77

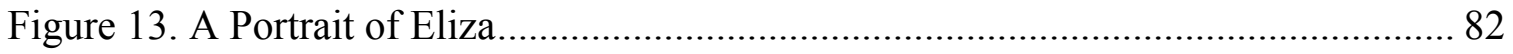

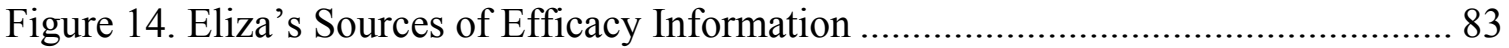




\section{Chapter 1: Introduction}

I am not really sure how I learned to write. My earliest memories in elementary school are of the handwriting paper (thin wide-spaced newsprint), fat pencils with huge erasers, and touching the lines when forming the letters of the alphabet. In all honesty, writing was a struggle because I am left-handed and I was constantly being forced to write with my right hand, which I remember felt awkward and uncomfortable. I remember copying Mother's Day and Father's Day poems that the teacher wrote on the chalkboard. I remember completing endless phonics, grammar, and spelling worksheets but not once can I recall an authentic writing activity. High school was no different except for a creative writing class. I loved this class because my teacher always had something positive to say about my writing and my paper was not covered with the infamous red ink. I do not think the red ink would have been so bad had it helped me grow as a writer but unfortunately the focus was always on the mechanics of writing, not the content. I never believed my writing was good enough. In fact, I am not sure I knew or even understood what writing was. To this point, for me, the focus was on the physical aspects of handwriting, copying someone else's words, and responding to prompts.

During college, I was devastated because the instructor, whom I really respected, wrote on my paper that he was "somewhat disappointed in the content" of my paper. I have no problem accepting criticism however; there were no suggestions on how to improve the content. It was not until I was in graduate school that I truly believed that I was capable of being a good writer. In a course, specifically focusing on writing, we were asked to write about one special moment in our life that we remembered with absolute clarity, one 
that we knew we would hold onto for years and years, and craft a lead using dialogue or sensory details. As I sat there and pondered, this is the lead I crafted:

With the touch of a trembling hand, the sound of steadily beeping machines, the taste of salty tears, and the smell of death, she slipped away to a place where there was no more pain or suffering. Her journey was filled with countless needles, noisy machines, and bruised arms. Cancer had reached out its ugly arms and sucked the precious life right out of her.

Even though it was only a few words from the instructor ("The writing piece about your mom took my breath away. Gorgeous!"), it was at this precise moment that I felt empowered as a writer. I felt efficacious as a writer. Why had it taken so long?

Writing is not only fundamental but learning to write is a "gateway to empowerment, yet, it is not a natural activity" (Cremin \& Myhill, 2012, p. 10). Writing is a complex and demanding task that is unlike other activities. Many other activities, which are hard to learn, improve with practice. However, writing remains a "highly demanding activity even as we become more experienced" (Cremin \& Myhill, 2012, p. 10).

The adopted Common Core State Standards (CCSS) have placed writing "at the center of the educational reform movement in the United States, making writing a more integral part of the curriculum and learning” (Graham \& Harris, 2015, p. 457). According to the CCSS, students are expected to learn how to write for multiple purposes (e.g., to narrate, to inform, to persuade) and use writing to recall, organize, analyze, interpret, and build knowledge (Graham \& Harris, 2013). While it is fundamental, it is really hard. It is not only challenging for students but can be a stressful endeavor for teachers to effectively teach and facilitate writing in the classroom. When students lack confidence 
in their writing skills, they are less likely to engage in tasks in which writing is required and they will more quickly give up when faced with this challenge (Pajares, 2007). Writing is complex because it involves the use and coordination of numerous cognitive processes that engage several sub-processes, for example, topic selection, planning, accessing prior knowledge, generating ideas, rehearsing, attending to spelling and handwriting, reading, organizing, editing, and revising (Chapman, 2006). It is a demanding task and as Kellogg (2008) posits engaging in a writing task is as mentally challenging as playing chess. Yet despite having established how difficult writing is, in schools it is often overlooked. In 2003, writing was deemed as the neglected "R" (National Commission on Writing in America's Schools and Colleges, 2003). The effects of being "neglected" are clear.

In 2011, the National Assessment of Educational Progress (NAEP) reported that only $27 \%$ of assessed students performed at or above the proficient level in writing (National Center for Education Statistics, 2012) continuing a trend of severely low performance from previous years. Prior to $2011,25-30 \%$ of students scored proficient on the annual NAEP writing assessment (National Center for Education Statistics, 2012). Despite these dismal scores, studies have found that students are not provided with the opportunity to write in the context of classroom instruction (Atwell, 1987; Graham \& Perin, 2007). Cutler and Graham (2008) found that first, second, and third grade students spent only 21 minutes per day writing, while Graham and Harris (2009) found that elementary students spent 25 minutes per day writing. Based on a six-hour school day, the time spent on writing is minimal. 
Acknowledging the many factors that may contribute to our failing scores, this study highlights teacher's critical role in changing these trends. Teachers play a key role in the academic success of students (Darling-Hammond \& Bransford, 2005), yet studies reveal that teachers do not feel confident to teach writing (e.g., Gilbert \& Graham, 2010; Graham \& Sandmel, 2011; Landon-Hays, 2012; Rapp, 2009). Some teachers do not feel they learned to write well during their own childhood experiences (Graves, 2002), which can possibly lead to a lack of self-confidence in their own writing. Teachers who are less apprehensive about their own writing assign more writing tasks than teachers who are apprehensive (Claypool, 1980). Does this lack of efficacy contribute to a resistance to teach writing?

Various scholars have conceptualized teacher self-efficacy (e.g., Ashton, 1984; Guskey \& Passaro, 1994; and Tschannen-Moran, Woolfolk-Hoy, \& Hoy, 1998). The conceptualization of teacher self-efficacy that grounded this study is that of scholars Tschannen-Moran, et al. (1998) who state, "the teacher's belief of his or her capability to organize and execute courses of action required to successfully accomplish a specific teaching task in a particular context" (p. 233).

Teachers' sense of efficacy is a powerful construct related to a number of positive student outcomes. Students of teachers with high teaching efficacy, compared to their colleagues taught by low efficacy teachers, have improved achievement, higher selfefficacy, positive attitudes regarding school, greater interest in school, more motivation, and a greater likelihood to recognize that what they are learning is essential (Henson, 2002; Tschannen-Moran, et al., 1998). Teachers with a higher sense of efficacy tend to provide better quality instruction, investigate instructional ideas, and implement more 
effective classroom management strategies (Graham, Harris, Fink, \& MacArthur, 2001; Tschannen-Moran et al., 1998). These teachers are also more likely to work longer with struggling students, are less likely to refer students for special education services (Graham et al., 2001; Poddell \& Soodak, 1993; Soodak \& Podell, 1996), believe that difficult students are reachable, view classroom issues as manageable by being resourceful and putting forth extra effort (Ashton \& Webb, 1986), and spend more time teaching in content areas where their sense of efficacy is higher (Riggs \& Enochs, 1990).

A teachers' sense of efficacy is a multidimensional construct. Various scholars have labeled these two constructs differently. For example, Ashton and Webb (1986) and Gibson and Dembo (1984) have labeled the two constructs as "teaching efficacy" and "personal teaching efficacy" whereas Hoy and Woolfolk (1990) opted to label these constructs "general teaching efficacy" and "personal teaching efficacy" (Coladarci, 1992, p. 324). Personal teaching efficacy is a teacher's expectation that he or she will be able to perform the actions that lead to student learning, while general teaching efficacy is the belief that the teacher's ability to perform these actions is limited by factors beyond school control (Ross, 1994).

Measuring teacher self-efficacy is not without challenges. Over the years several measures have been developed to measure teacher self-efficacy (i.e., Gibson \& Dembo, 1984; Guskey, 1981; Riggs \& Enochs, 1990; Rose \& Medway, 1981) grounded in either Bandura's (1977) or Rotter's (1966) work. In their seminal work Tschannen-Moran and her colleagues (1998) reviewed teacher efficacy literature and examined the concepts fundamental to teacher efficacy not only to clarify the construct but also improve how it was measured. They proposed an integrated model of a teacher's perceived competence, 
the task facing the teacher, and the context in which the task was situated (TschannenMoran, et al., 1998). A teacher may feel very confident in his or her ability to impact student learning in reading and mathematics but not writing or science.

Although teaching self-efficacy has been recognized as a significant construct associated with teacher competence (Goddard, Hoy, \& Woolfolk Hoy, 2000), research is limited to how teachers perceive of themselves as writers (i.e. writing self-efficacy), specifically as it relates to their writing instruction (Rapp, 2009). "Vigorous theoretical support and research evidence supports the hypothesis that teachers should be readers and writers to be effective teachers of reading and writing" (See Atwell, 1987, 1991; Augsburger, 1998, Calkins, 1993; Graves, 1978, 1984, 1990, 1994; Murray, 1968, 1985, 1989 as cited in Brooks, 2007, p. 178). To be effective teachers of reading and writing, teachers must experience the challenges that their students are confronted with daily. As Bomer (2010) so eloquently posits, "Teaching writing without doing it ourselves is like trying to teach a four-year-old how to tie shoes when we have only worn flip-flops our entire life" (p. 77). Teachers not only have the ability to impact the quality of their student's writing but also their self-efficacy in their own writing abilities. Pajares (2007) argues, "When academic challenges erode students' self-efficacy in their writing capability, it will be difficult to improve this capability without shifting the self-efficacy beliefs that are influential in forming and nurturing it" (p. 246).

It should be noted that the term teacher efficacy can often be confused with the concept of teacher effectiveness. The literature routinely uses the terms teacher's sense of efficacy or teacher self-efficacy (Shaughessy, 2004) to reduce linguistic and conceptual confusion. This study uses the terms that are routinely used in the literature. 
It should also be noted that many times self-efficacy is confused with self-esteem. Self-efficacy and self-esteem are different in that self-efficacy is domain, context, and task specific. Bandura (1997) states:

Perceived self-efficacy is concerned with judgments of personal capability, whereas, self-esteem is concerned with judgments of self-worth. Individuals may judge themselves hopelessly inefficacious in a given activity without suffering any loss of self-esteem whatsoever, because they do not invest their self-worth in that activity. Conversely, individuals may regard themselves as highly efficacious in an activity but take no pride in performing it well (p. 11).

For example, a person may not know how to dance and may have a low self-efficacy for dancing, but that does not result in low self-esteem if dancing is not important in his or her life.

Self-efficacy and self-concept differ in that self-efficacy is context-specific and self-concept includes beliefs of self-worth associated with one's perceived competence (Pajares \& Miller, 1994). Beliefs about confidence are part of an individual's selfconcept, nonetheless Bandura (1986a) claimed that self-concept and self-efficacy represent different phenomena and must not be mistaken for each other (Pajares \& Miller, 1994). In addition, it is important to remember that self-efficacy focuses on individuals' perceptions of what they believe they can do given their skills and abilities rather than the actual skills and abilities they possess.

\section{Purpose of the Study}

The purpose of this study was to investigate how the domain specific efficacies might assemble themselves within an individual. In other words, how might issues relating to a generalized sense of self-efficacy relate to self-efficacy in teaching and how 
might those relate to writing? What might be the interaction between these individual self-efficacies? Does one inform the other? Can you have divergent self-efficacies based on different domains?

\section{Significance of the Study}

The findings of the study will build upon the research for writing self-efficacy and teaching writing self-efficacy by exploring the experiences of five elementary classroom teachers. Developing an understanding of how the domain specific efficacies manifest themselves in the teaching of writing is an important step in improving teacher quality and positively impacting student outcomes. According to Tschannen-Moran and Woolfolk Hoy (2001),

Exciting possibilities lay ahead as we learn more about this simple yet powerful idea. If the significant effects of teachers' beliefs in their capabilities were taken seriously, it could provoke significant changes in the way teachers are prepared and supported in their early years in the profession (p. 802).

Cultivating teachers' self-efficacy as writers and teachers of writing may perhaps be the starting place for developing positive self-efficacies toward writing in our students.

\section{Definition of Terms}

In this section key terms used throughout this study are defined for clarification of their meaning.

Self-efficacy: beliefs about his or her personal ability to learn and perform actions to a certain degree; it is specifically related to one's belief about his or her ability to perform a task, not necessarily one's knowledge of what or how to perform the task (Bandura, 1977). 
Writing self-efficacy: judgments of one's own writing capabilities and skills needed to perform various writing tasks (Pajares \& Johnson, 1993)

Teacher self-efficacy: A teacher's belief in his or her capability to organize and execute courses of action required to successfully accomplish a specific teaching task in a particular context (Tschannen-Moran, et al., 1998)

Teaching writing self-efficacy: a teacher's belief in his or her capability to teach writing.

\section{Assumptions}

The following assumptions were made in conducting this study:

1. The participants would respond to the surveys and interviews as truthfully and thoroughly as possible in a manner that reveals their self-efficacy and instructional practices.

2. The researcher is knowledgeable of the writing process.

\section{Limitations}

The researcher acknowledges the following limitations:

1. As is true of other research about self-efficacy, all data collected in this study will be self-reported data.

2. The participants will be all in-service teachers at the elementary level.

3. This study will focus on the domain specific self-efficacies (general self-efficacy, writing self-efficacy, teacher self-efficacy, and teaching writing self-efficacy) and will not address other factors that might relate to teachers' resistance to teach writing. 
4. This study will also be limited in that the surveys will be delivered through the Internet, allowing for the possibility of misinterpretation of the directions and questions.

\section{Organization of the Study}

This dissertation is organized into five chapters. Chapter 1 provides an

introduction to the study, the purpose of the study, the research question, significance of the study, terms and definitions, assumptions, limitations, and organization of the study. Chapter 2 offers the theoretical framework and reviews the literature that has examined other studies of similar context. Chapter 3 explains the participant selection, data collection, and data analysis. Chapter 4 presents individual portraits of the participants. Chapter 5 discusses the conclusions and implications of the study. 


\section{Chapter 2: Literature Review}

\section{Overview}

The purpose of this was to understand how the domain specific self-efficacies might assemble themselves within an individual. The first part of this chapter provides a theoretical framework that serves as a basis for understanding the context in which this study is situated. The second part of this chapter reviews the relevant literature that has looked at other studies.

\section{Theoretical Underpinnings and Conceptual Framework}

The conceptual framework for this study begins with the general construct of selfefficacy, the specific construct of writing self-efficacy, teacher self-efficacy and finally teacher self-efficacy in the context of writing. Each of these constructs plays a role in developing an understanding of how self-efficacy manifests itself in the teaching of writing.

\section{Social Cognitive Theory}

Bandura's (1986a) social cognitive theory is multifaceted and is grounded in a view of human agency in which individuals are agents proactively involved in their own development and can make things happen by their actions (Pajares, Johnson, \& Usher, 2007). Fundamental to this sense of agency, individuals have self-beliefs that allow them to control their thoughts, feeling, and actions; in other words, "what people think, believe, and feel affects how they behave" (Bandura, 1986a, p. 25). This theory is composed of four processes of goal realization: self-observation, self-evaluation, self-reaction, and self-efficacy (Bandura, 1995). Self-efficacy is theorized as the most influential mediator in human agency and helps explain why people's behaviors may differ significantly even when they have similar knowledge and skills (Pajares \& Johnson, 1994). 


\section{The Construct of Self-Efficacy}

Self-efficacy is a key construct of Bandura's social cognitive theory. Bandura (1997) defines self-efficacy as “beliefs in one's capabilities to organize and execute the courses of action required to produce given attainments" (p. 3) and clarifies that selfefficacy "is not concerned with the skills one has but with judgments of what one can do with whatever skills one possesses" (Bandura, 1986a, p. 391). An individual's selfefficacy is shaped and reinforced by two psychological processes: efficacy expectations and outcome expectations (Bandura, 1977). Efficacy expectation is the belief that one can successfully implement a behavior required to produce a given outcome. Outcome expectation is an individual's approximation that a given behavior will lead to a specific outcome and is determined by self-efficacy.

Bandura (1986a) theorized that individuals are not just efficacious or not, but the level of efficacy is a domain-specific construct that is contingent upon the context. Most people judge themselves to be reasonably efficacious in domains in which they have established their competencies, moderately efficacious in domains in which they are somewhat less established, and inefficacious in domains that severely strain their capabilities (Bandura, 1997).

Self-efficacy differs from other forms of self-belief in its specificity to a distinct skill, activity, or domain. Distinct from self-concept or self-esteem, which are global traits of the self, self-efficacy varies among different activities, levels of difficulty within the same activity, and under different conditions (Bandura, 1977). Because of this specificity self-efficacy has been shown to be a more reliable predictor of achievement than other forms of self-belief. 
In his seminal research, Bandura (1997) proposed that four sources contribute to the development of self-efficacy: (a) mastery experiences (actively performing tasks), (b) vicarious experiences (seeing others perform), (c) social or verbal persuasion (feedback from others), and (d) physiological or emotional responses (mental and physical wellness). The most influential source of creating a strong sense of efficacy is based on personal mastery experiences because they provide the "most authentic evidence of whether one can muster whatever it takes to succeed" (Bandura, 1997).

Efficacy beliefs vary in level, generality, and strength (Bandura, 1977). Level refers to the varying degrees of complexity for a certain task. Generality denotes the transfer of efficacy beliefs across different domains. Strength indicates the degree of certainty that one can perform a given task.

Self-efficacy influences task choice, persistence, resilience, and achievement (Bandura, 1977). Research also points to self-efficacy as a predictor of writing outcomes, thus inextricably and inarguably linking the two concepts (Pajares et al., 2007).

Self-efficacy theories serve as the foundation on which the rest of the theoretical framework is developed for this particular study.

\section{The Construct of Writing Self-Efficacy}

According to Pajares and Johnson (1993), "writing self-efficacy beliefs are individuals' judgment of their competence in writing, specifically their judgment of their ability to write different writing tasks and of their possession of varying composition, usage, and mechanical skills" (p. 11). Beliefs of writing self-efficacy are a result of a student's interpretation of his or her own previous experiences and performance (Pajares et al., 2007). Research supports that students internalize their prior experiences (success 
and failures) with writing to form perceptions of their capabilities and willingness to act in accordance with their perceptions of their abilities when engaging in subsequent tasks requiring writing (Pajares, 1996; Pajares et al., 2007; \& Wachholz and Etheridge, 1996).

Bandura's outcome expectancy and efficacy expectations (as discussed above) have an important bearing on understanding how students learn to write (McCarthy, Meier, \& Rinderer, 1985). This means that even if an individual knows what is expected to produce an effective piece of writing, as well as the steps necessary to produce the piece, but lacks the belief that he or she can achieve the desired outcome, then effective behavior will likely not result (McCarthy, et al., 1985).

Writing self-efficacy beliefs may vary in level, strength, and generality. For example, when writing an essay, the levels can vary from the lower level of writing a simple sentence with proper punctuation to the higher level of organizing sentences into a paragraph (Pajares \& Valiante, 2006). The strength is the belief in the capacity to perform at each of the levels identified while the generality refers to the range of activities included in the perception of a task (Pajares, 2003). Individuals do not characteristically judge themselves equally efficacious across all types of language arts activities or even across all types of writing (Pajares, 2003; Pajares \& Valiante, 2006).

Research has consistently shown that writing self-efficacy beliefs and writing performance are related, writing self-efficacy beliefs are correlated with variables such as writing anxiety, grade goals, depth of processing, and expected outcomes, and neither writing apprehension nor other motivation variables are typically predictive of writing performance in regression models that include self-efficacy (Pajares, 2003; Pajares \& Johnson, 1994). 


\section{The Construct of Teacher Self-Efficacy}

Teacher efficacy is a well-studied field supported by a sizeable body of research. A teacher's sense of efficacy is typically recognized as an important attribute of effective teaching and has been positively correlated to teacher and student outcomes results (Tschannen-Moran, et al., 1998). Teacher self-efficacy research has emerged from two theoretical strands: Rotter's (1966) locus of control theory and Bandura's (1977) social cognitive theory. Rotter's theory is most often cited as the foundation that guided the first efficacy studies conducted by the RAND researchers (Tschannen-Moran, et al., 1998).

A second and more dominant strand of research grew out of Bandura's (1977) integrative approach of social cognitive theory and the construct of self-efficacy. Bandura (1977) differentiates locus of control and self-efficacy in that locus of control is focused on who or what has control of outcomes and self-efficacy is concerned with an individual's future-oriented evaluation of one's capabilities in a specific context (Bandura, 1986a).

Attempting to integrate the two strands of teacher self-efficacy Tschannen-Moran and her colleagues (1998) proposed a cyclical model (see Figure 1) and defined teacher efficacy as "the teachers' belief in his or her capability to organize and execute courses of action required to successfully accomplish a specific teaching task in a particular context (p. 233). Tschannen-Moran and her colleagues (1998) posit, "It is in making explicit the judgment of personal competence in light of an analysis of the task and situation that our model improves upon previous models" (p. 233).

In examining this model, Bandura's (1977) four sources of efficacy contribute to both the analysis of the teaching task and to the assessment of personal teaching 
competence, while cognitive processing determines what information is attended to, how the different sources of information will be weighed and how they are interpreted (Tschannen-Moran et al., 1998). The analysis of the teaching task requires teachers to determine what will be required of them (resources and contextual factors) in order to determine how challenging the teaching task may be, while the assessment of personal teaching competence relates to the teacher's belief about his or her current abilities to accomplish the teaching task effectively (Tschannen-Moran et al., 1998). At this point a teacher assesses his or her self-perceptions of personal teaching competence while considering the assumed requirements of the teaching task. It is the collaboration of these two components that shapes teacher efficacy. The judgments of teacher efficacy impact the teacher's task performance in areas such as instructional goals, effort put forth in teaching, and persistence and resilience in the face of challenges. Tschannen-Moran and colleagues (1998) theorize:

The proficiency of a performance creates a new mastery experience, which provides new information that will be processed to shape future efficacy beliefs. Greater efficacy leads to greater effort and persistence, which leads to greater performance, which in turns leads to greater efficacy. The reverse is also true (p. 234). 


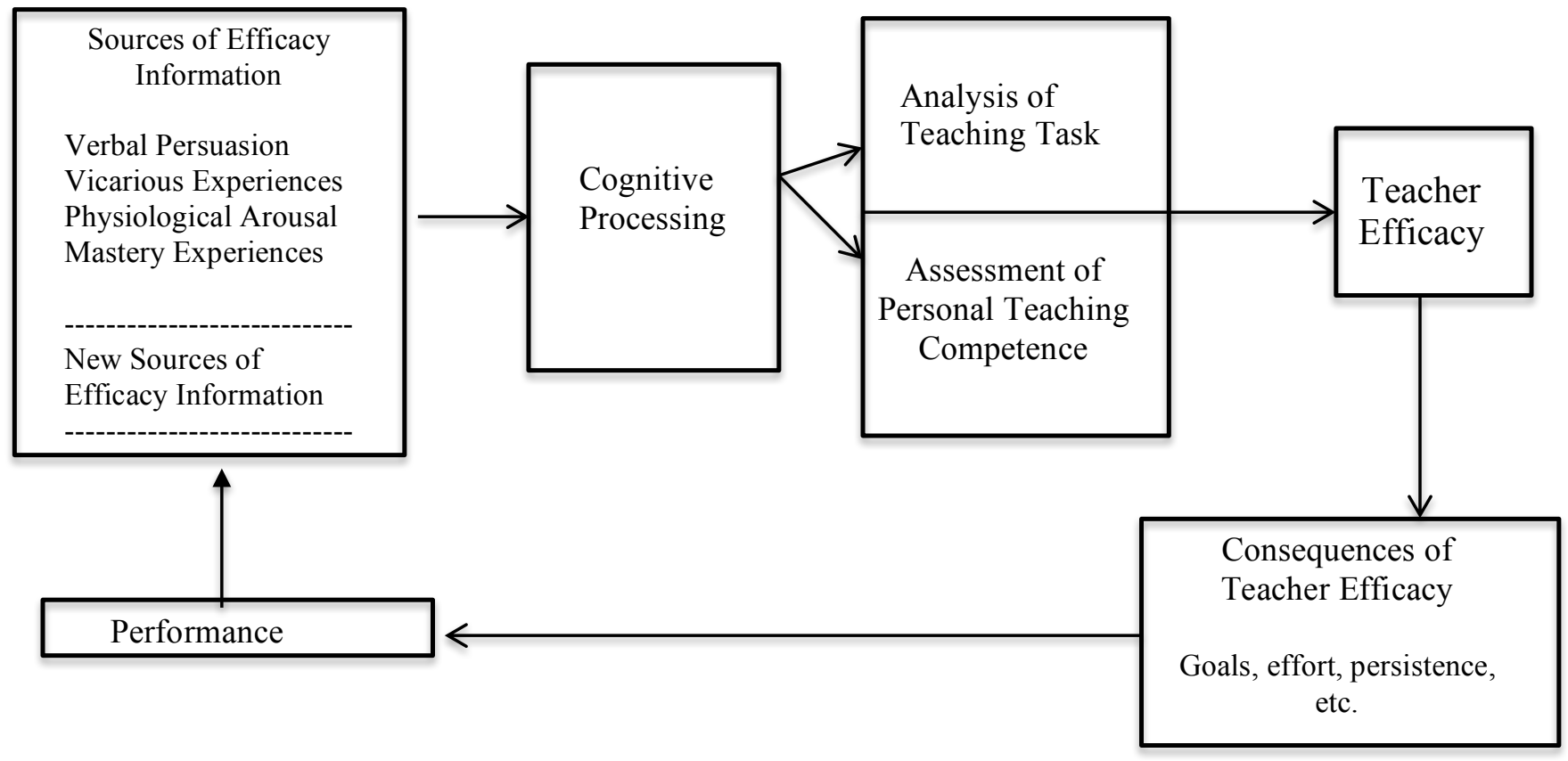

Figure 1. Integrated Model of Teacher Self-Efficacy Beliefs

(Tschannen-Moran et al., 1998, p. 228)

The cyclical nature of this model is what makes it so powerful (Tschannen-Moran et al., 1998) in that accomplishing a teaching performance creates a new mastery experience that refers to the sources of efficacy experience and incorporates new information.

It is this integrated model of teacher efficacy that was instrumental in developing the theoretical framework of the current study. This study was designed to explore teacher's self-efficacy and how it manifests itself in the teaching of writing. This model emphasizes not only the importance of the teachers' perception of the requirements of the teaching task but also the teachers' beliefs about her own ability to perform the task. Teachers do not necessarily feel equally efficacious in all situations but feel "efficacious for teaching particular subjects to certain students in specific settings" (Tschannen-Moran et al., 1998, p. 227). 


\section{The Construct of Teacher Efficacy in the Context of Writing Instruction}

Teacher self-efficacy is specific to the content matter and context, and may vary among the various content areas (Bandura, 1997; Tschannen-Moran et al., 1998). Domain specific efficacy, such as teaching writing, refers to a teacher's perceived ability to teach writing. I conceptualized this construct as building from multiple domains: general selfefficacy, writing self-efficacy, and teacher self-efficacy (see Figure 2).

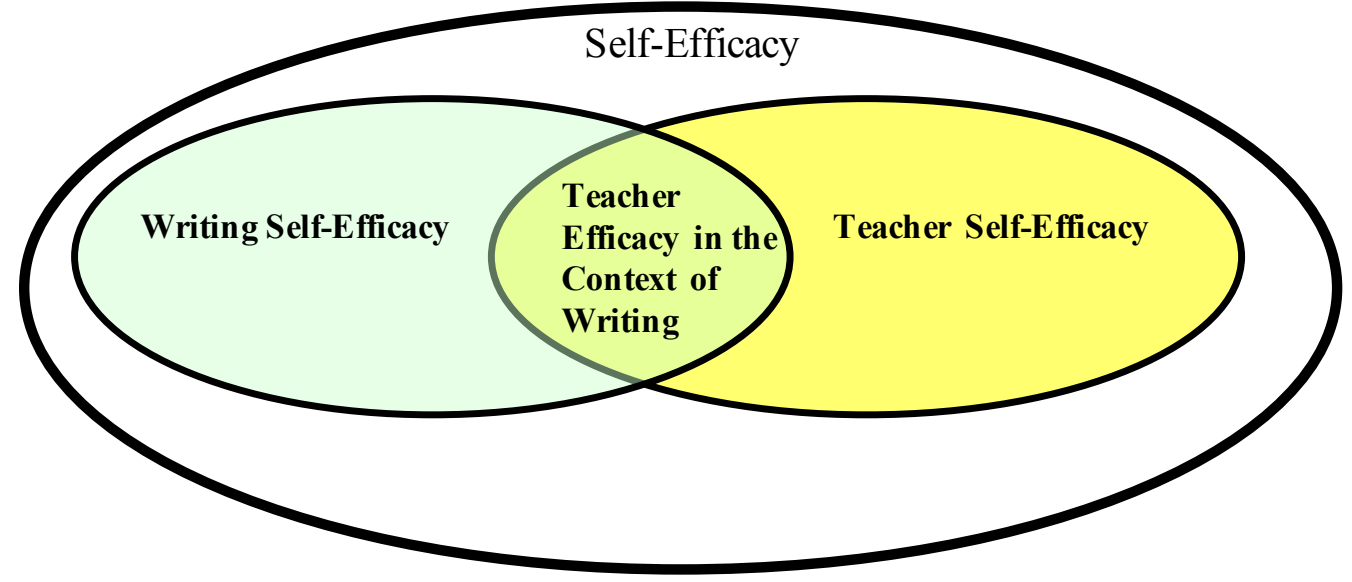

Figure 2. Conceptualization of the Multiple Domains

The central component of this construct is teacher self-efficacy in the context of writing instruction, a teacher's belief in her ability to teach writing that is formed in part by her views of herself as a writer in which both positive and negative experiences influence this perception (see Figure 3). Being an effective teacher of writing requires not only content knowledge and skills but also the belief in one's capabilities to impact student learning (Graham et al., 2001), however, many teachers feel they may lack understanding of the complexities of content knowledge and skill in the domain of writing instruction (Gilbert \& Graham, 2010). We know that teachers are the most important component in the classroom (Graves, 1990), and their "past and current writing experiences along with 
their self-efficacy as writers and teachers of writing likely will be keys to their success" (Bruning \& Kauffman, 2016, p. 168). Teachers' writing self-efficacy is a central component of classroom teachers. Teachers who are apprehensive about their own writing abilities struggle with teaching writing and may give up when faced with student writing challenges (Pajares \& Johnson, 1994; Street \& Stang, 2009).

The model of self-efficacy described here is applied to the specific context of teaching writing. In this study, I apply the Integrated Model of Teacher Self-Efficacy Beliefs (Tschannen-Moran et al., 1998) to the construct of teacher efficacy in the context of writing instruction. While much of the model stays the same, I propose that there are two levels of the four sources of efficacy information that influence teachers' cognitive processing: those related to writing and those related to the teaching of writing. These multilayered sources of efficacy can inform the process of evolving efficacy in writing instruction and in addition the interactions between the sources can work to strengthen or weaken each other. Information obtained from these four sources does not automatically influence self-efficacy; rather, it is cognitively appraised by the individual (Bandura, 1986a); in this case the teacher. 


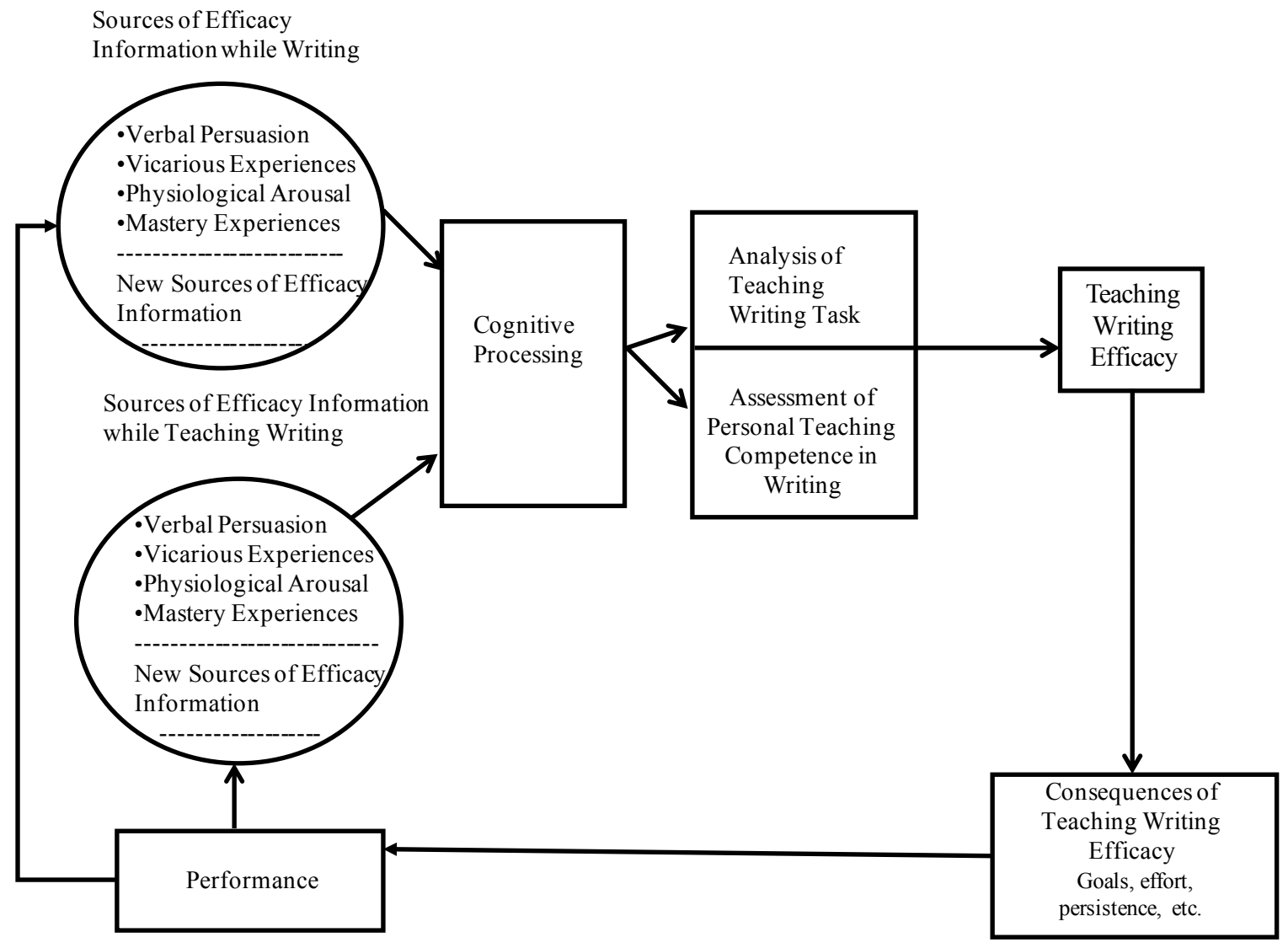

Figure 3. Proposed Integrated Model of Teacher Self-Efficacy Beliefs in the Domain of Writing

Adapted from: Integrated Model of Teacher Self-Efficacy Beliefs (Tschannen-Moran et al., 1998, p. 228).

If Tschannen-Moran and her colleagues' model is applied to teacher efficacy in the context of writing, working through the model, from the teacher's perspective, is as follows: The teacher has had a range of influential experiences that serve as sources of efficacy information while writing as well as while teaching writing (see Table 1). Although all four sources of efficacy information contribute to the formation of efficacy beliefs, it is the cognitive processing that determines how the sources will be interpreted (Tschannen-Moran et al., 1998). Through cognitive processing, teachers interpret the 
information they receive to frame and reframe the task of teaching writing and the assessment of personal teaching competence in teaching writing. Questions asked by the teacher in analyzing the teaching task and its context might include: What does success in the teaching of writing look like? What will be required to teach writing at this particular time in this particular situation? What instructional strategies will best meet the needs of my students? Each teacher must answer these questions for her context, as the criteria for success in one setting might not be the same as in another. Questions asked by the teacher in assessing personal teaching competence in writing might include: Do I have the knowledge to assess student's writing performance? Am I able to determine what steps are needed to move this student to the next level? In answering these questions a teacher makes a judgment of his or her sense of efficacy, which is an estimate of whether his or her current knowledge and abilities are sufficient for the task of teaching writing. A teacher who is cognizant of deficits in her capabilities in the teaching of writing and has a conviction about how those deficits can be addressed has a resilient sense of efficacy for teaching writing. The level of efficacy determines the teaching performance, which becomes a new source of efficacy information. Thus, greater efficacy leads to greater effort and persistence, which leads to better performance, which leads to greater efficacy and the cycle continues (Tschannen-Moran et al., 1998). As the model comes full circle, "a teaching performance that was accomplished with a level of effort and persistence influenced by the performer's sense of efficacy, when completed, becomes the past and a source of future efficacy beliefs" (Tschannen-Moran et al., 1998, p. 234).

If one feels more efficacious they will seek more opportunities that will feed the cycle. They will continue to teach more writing which gives them more potential sources 
of efficacy. Conversely, someone who feels less efficacious potentially teaches writing

less and generates fewer and fewer sources of efficacy to feed the cycle; therefore, causing self-efficacy to become weaker and weaker.

Table 1

Sources of Efficacy Information

\begin{tabular}{|c|c|c|c|c|}
\hline $\begin{array}{c}\text { Source of } \\
\text { Efficacy } \\
\text { Information }\end{array}$ & Description of Source & Influence of Source & $\begin{array}{c}\text { Example of Efficacy } \\
\text { Information while } \\
\text { Writing }\end{array}$ & $\begin{array}{l}\text { Example of Efficacy } \\
\text { Information while } \\
\text { Teaching Writing }\end{array}$ \\
\hline $\begin{array}{l}\text { Mastery } \\
\text { Experiences } \\
\text { (past } \\
\text { performances) }\end{array}$ & $\begin{array}{l}\text { Positive and negative } \\
\text { personal experiences } \\
\text { that can influence the } \\
\text { perception of the ability } \\
\text { to perform a task } \\
\text { (Bandura, 1997) }\end{array}$ & $\begin{array}{l}\text { Strong efficacy } \\
\text { expectations are } \\
\text { developed through } \\
\text { repeated successes, } \\
\text { while failures undermine } \\
\text { and weaken self-efficacy }\end{array}$ & $\begin{array}{l}\text { Repeated successes on } \\
\text { narrative writing } \\
\text { assignments }\end{array}$ & $\begin{array}{l}\text { Teaching an } \\
\text { unsuccessful lesson on } \\
\text { poetry }\end{array}$ \\
\hline $\begin{array}{l}\text { Physiological } \\
\text { Arousal }\end{array}$ & $\begin{array}{l}\text { Physical and emotional } \\
\text { states that individuals } \\
\text { experience while } \\
\text { performing a particular } \\
\text { task } \\
\text { (Bandura, 1997) }\end{array}$ & $\begin{array}{l}\text { Positive energy and } \\
\text { emotions will increase } \\
\text { self-efficacy, while } \\
\text { negative energy } \\
\text { (nervousness and } \\
\text { anxiety) usually hinders } \\
\text { performance }\end{array}$ & $\begin{array}{l}\text { Feeling agitated, } \\
\text { anxious, having sweaty } \\
\text { palms, when asked to } \\
\text { complete a writing } \\
\text { assignment }\end{array}$ & $\begin{array}{l}\text { Pride and warmth in } \\
\text { seeing a "light bulb" } \\
\text { moment for a student }\end{array}$ \\
\hline $\begin{array}{l}\text { Vicarious } \\
\text { Experiences } \\
\text { (modeling) }\end{array}$ & $\begin{array}{l}\text { When an individual sees } \\
\text { someone with perceived } \\
\text { similar ability perform a } \\
\text { task (Bandura, 1997) }\end{array}$ & $\begin{array}{l}\text { Seeing an individual } \\
\text { succeed can increase } \\
\text { self-efficacy to do the } \\
\text { same, however, seeing } \\
\text { an individual fail can } \\
\text { lower self-efficacy }\end{array}$ & $\begin{array}{l}\text { Witnessing another with } \\
\text { perceived similar } \\
\text { abilities not succeed at } \\
\text { writing an expository } \\
\text { piece }\end{array}$ & $\begin{array}{l}\text { Observing an individual } \\
\text { who is like oneself } \\
\text { successfully teach a } \\
\text { particular writing } \\
\text { strategy. } \\
\text { "If you can do it, I can } \\
\text { do it." }\end{array}$ \\
\hline $\begin{array}{l}\text { Verbal } \\
\text { Persuasion }\end{array}$ & $\begin{array}{l}\text { When individuals are } \\
\text { verbally persuaded that } \\
\text { they are capable of } \\
\text { success (Bandura, 1997) }\end{array}$ & $\begin{array}{l}\text { Self-efficacy is likely to } \\
\text { increase when the } \\
\text { feedback is supportive } \\
\text { and specific, but will } \\
\text { diminish with criticism }\end{array}$ & $\begin{array}{l}\text { "The writing piece about } \\
\text { your mom took my } \\
\text { breath away. Gorgeous!" }\end{array}$ & $\begin{array}{l}\text { Your writing lesson on } \\
\text { adding details was } \\
\text { difficult for the students } \\
\text { to follow. }\end{array}$ \\
\hline
\end{tabular}

\section{Previous Studies Exploring Writing Self-Efficacy and Teaching of Writing Self- Efficacy}

Because the constructs of self-efficacy and teacher efficacy have a relatively wellestablished body of research, the studies reviewed here will specifically focus on the constructs of writing self-efficacy and teachers' writing self-efficacy. Efficacy can vary significantly based on content area, activities, task, students, and classroom situations. Research supports that self-efficacy is task-specific and is influenced by the successful accomplishment of a task (Klassen, 2002; Bandura, 1997). Domain specific teacher self- 
efficacy studies have been conducted in the fields of science, reading, and math, however, the studies in the field of writing are limited (Klassen, Tze, Betts, \& Gordon, 2011).

Writing Self-Efficacy. Self-beliefs about writing have received limited attention from both researchers in the field of composition and from self-efficacy researchers (Pajares, 2003). Although limited, research studies on student writers from elementary school to college have consistently shown that writing self-efficacy and writing performance is related (e.g., McCarthy, et al., 1985; Pajares, 2003; Pajares \& Johnson, 1994; Pajares \& Johnson, 1996; Shell, Murphy, \& Bruning, 1989). The level of an individual's self-efficacy beliefs can have a positive or negative effect on writing performance. An individual who holds a positive self-efficacy may be inclined to view difficult tasks as a challenge, while individuals with a negative self-efficacy may be inclined to avoid tasks that are perceived as too challenging (Bandura, 1994). Kim and Lorsbach's (2005) study lends support to Bandura's notion in the specific domain of writing. They found that students in kindergarten and grade one tended to confirm the same results of the research examining older learners. Those students who exhibited a high writing self-efficacy were willing to try, were risk takers, spent longer time to complete a task, were eager to participate in writing, and wanted to get a good grade. Those students with low writing self-efficacy avoided a task when that task was too difficult to accomplish. Researchers have also found that writing self-efficacy beliefs were correlated with variables such as writing anxiety, grade goals, depth of processing, and expected outcomes (Pajares, 2003). 
While self-efficacy as a general construct has been explored with children, adolescents, and adults, self-efficacy in the domain of writing has primarily been examined with K-16 students. This work has been helpful for laying the groundwork of understanding self-efficacy in writing; however, it has been looked at almost exclusively in quantitative measures. My study extends this inquiry into writing self-efficacy with adults.

Writing Self-Efficacy of Practicing Teachers. While the studies previously mentioned examined students' writing self-efficacy, the focus of this study is practicing classroom teachers. The literature related to teacher self-efficacy in respect to themselves as writers is limited. From those studies, we know the following: First, when teachers are provided with the opportunity to become engaged in writing as well as being able to connect to the experiences of other teachers, writing self-efficacy increases (Frank, 2003). Second, writing self-efficacy is a key ingredient to understanding how it is that teachers think about their own writing and what they do when faced with a particular writing task (Lavelle, 2006). Third, teachers must know what writing is like as a writer if they will ever be able to teach their students to write well (Street \& Stang, 2009).

There are limitations of the current literature. First, there is very limited work. Second, only one study examined elementary teachers. Third, of the few studies that did examine self-efficacy and writing, those studies examined the implications for selfefficacy on writing. Through my study I contend that being self-efficacious in writing may have implication for the teaching of writing and this connection has yet to be examined by the literature. 
Teacher Self-Efficacy in the Context of Writing Instruction. While there have been some studies that have explored self-efficacy in the teaching of writing most of these studies have looked at the effects of some sort of professional development intervention on teacher self-efficacy and teaching writing. For example, Troia, Lin, Cohen, and Monroe (2011) looked at the effect of writer's workshop on elementary teachers, while Lock, Whitehead, and Dix (2013) studied high school teachers. Dix and Cawkwell (2011) followed the journey of one primary teacher who was involved in a National Writing Project writing workshop experience. These studies contribute to an understanding of teaching writing self-efficacy in that self-efficacy was enhanced or increased. What these studies lack, however, is a way to provide us information about teachers who have not had an intervention.

There are few studies examining teacher efficacy to teach writing in the elementary classroom (Graham et al., 2001; Lavelle, 2006); more specifically, selfefficacy for teaching writing has mostly been investigated through adaptations of teaching self-efficacy measures or measures to examine literacy in general (Graham, et al., 2001). Only one study was located that examined teacher efficacy in the domain of writing.

In response to very little research concerning teacher efficacy in the domain of writing, Graham and his colleagues (2001) modified the Teacher Efficacy Scale designed by Gibson and Dembo (1984). The Teacher Efficacy Scale for Writing (TESW) was developed to measure teacher efficacy in writing with primary grade teachers (Graham, et al., 2001). The scale was used to examine how high and low efficacious teachers might vary in writing instruction methods. Self-efficacy beliefs impact the teaching of writing, 
in that the classroom practices in writing instruction of highly efficacious teachers differ substantially from that of low efficacious teachers (Graham, et al., 2001). Teachers with a high sense of efficacy reported that their students spent more time writing than did teachers with a low sense of efficacy (Graham, et al., 2001). Teachers with a high sense of personal efficacy reported that they spent more time teaching grammar and usage as well as basic writing processes than those with a low sense of personal efficacy (Graham, et al., 2001). It is imperative to note that these findings "are consistent with prior investigations showing that teacher efficacy predicts observed teacher practices" (e.g., Allinder, 1994; Ashton \& Webb, 1986; Stein \& Wang, 1988 as cited in Graham, et al., 2001, p. 197).

Graham and his colleagues (2001) posit that, "Given the apparent value of teachers' feelings of efficacy, it is surprising that this construct has been largely ignored in writing research" (p. 178). The purpose of my study is to go beyond the notion that self-efficacy exists and that it affects the teaching of writing. While I am informed by the literature on each element of self-efficacy, I want to uncover how these may be different elements of a more coherent sense of self-efficacy that relates to the teaching of writing. My study examines how these different ingredients may work together and how they may help refine my understanding of how multiple self-efficacies manifest themselves in the teaching of writing

\section{Summary}

While the referenced studies have been valuable in providing background for the current work, they are limited in helping teachers and teacher educators know how to address the issue of efficacy in teaching writing. For the most part the researchers in the field acknowledge and identify the phenomenon, however, they do not provide tools for 
teachers or teacher educators to make change in this area. A study that provides finegrained descriptions of how they work together and how it is manifested in instruction can move us towards a better understanding of how to support teachers and teacher educators.

It is vital to examine teacher efficacy as it relates to writing as we seek to improve writing instruction provided in our classrooms today. While teacher beliefs and attitudes have been clearly connected to teacher actions, understanding self-efficacy in combination with the epistemological beliefs of teachers can provide necessary insight into methods for improving teacher writing instruction (Pajares, 2003). As we know selfefficacy is such an impactful factor in so many other domains, it is worth exploring further in this domain. Developing an understanding of teachers' self-efficacy as it relates to writing could potentially provide college and university instructors, educational administrators, and policy makers' valuable information in meeting the challenges teachers of writing face as well as enhancing their practice and efficacy toward teaching writing. Graham (as cited in Zumbrunn \& Krause, 2012) stated, "The more prepared our teachers are, the more efficacious they are, the more likely they are to have students write and spend time teaching writing" (p. 348). 


\section{Chapter 3: Methods}

\section{Overview}

The purpose of this study was to understand how the domain specific selfefficacies might assemble themselves within an individual. In other words, how might issues relating to a generalized sense of self-efficacy relate to self-efficacy in teaching and how those might relate to writing? What might be the interaction between these individual self-efficacies? Does one inform the other? Can you have divergent selfefficacies based on different domains? Again, simply identifying high and low efficacious teachers will not provide information on the potential connection between self-efficacy and practice. What is needed is a deep understanding of these connections.

The conceptual framework that guided this study was built from TschannenMoran, Woolfolk Hoy and Hoy’s (1998) Integrated Model of Teacher Self-Efficacy Beliefs. In this study, I applied the Tschannen-Moran et al. (1998) model to the context of writing instruction (See Figure 3). I proposed that there are two levels of the four sources of efficacy information that influence teachers' cognitive processing: those related to writing and those related to the teaching of writing.

A teacher's sense of efficacy has been recognized as a vital attribute to effective teaching and has been referred to as the most powerful beliefs that teachers might hold (Tschannen-Moran et al., 1998). Research has established a link between teachers' general perceptions of efficacy and achievement, however, there is limited research regarding how teachers think of themselves as writers, specifically as it relates to the teaching of writing. What is needed in the literature and the profession is a fine-grained description of how efficacy or a lack of efficacy may be manifested in the teaching of writing. 
Self-efficacy and the connections between self-efficacy and practice are difficult to capture because self-efficacy is tacit, often not articulated, and because a range of things affect practice, not just self-efficacy. To address these challenges, this study was designed to try to understand these complex and often tacit relationships.

The purpose of this chapter is to describe the methodology that I employed as I conducted this study. This includes my position as a researcher, a description of how the participants for this study were identified as well as the methods used for locating and contacting the individual participants. This chapter also includes a description of the data collected and the methods used for data analysis.

\section{Researcher Positionality}

I am approaching this topic as a former elementary classroom teacher, Graduate Teaching Assistant, and adjunct faculty member. As I stated in Chapter 1, my initial experiences with writing were related to handwriting, copying someone else's words, responding to prompts, and learning the conventions of writing. I did not develop any sort of identity as a writer until graduate school when one of my instructors positioned me as a writer, which made me feel very different about teaching writing. I am reminded of the saying, "If I knew then what I know now."

As a classroom teacher, writing was not something I looked forward to teaching. I have always implemented the components of a workshop approach; however, I must admit I never fully understood the complexities of writing or teaching writing. My students had a writer's notebook neatly divided into sections for brainstorming ideas, works in progress, revision and editing checklists, and conferencing notes. In retrospect, my focus was on doing all the right things and not, as Katie Wood Ray (1993) posits, "focusing on writers who use writing to do powerful things in the world in which they 
live” (p. 5). I did not see myself as a writer nor did I feel efficacious as a writer or a teacher of writing.

As a Graduate Teaching Assistant and adjunct faculty member, I had the opportunity to work with preservice teachers. Many dreaded the thought of teaching writing and did not feel efficacious enough to do so. I understood where the preservice teachers were coming from because I had been there myself. I recognized the way in which we teach our preservice teachers literacy does not involve teaching them how to be writers or teachers of writing. It was at this point that I became passionate about the need to empower our preservice teachers with this knowledge. I recognize that knowledge and self-efficacy are two different ingredients, however, they are not unrelated. In response to this, I developed a course for preservice teachers that specifically focused on the domain of writing. The structure of the course was designed to have a dual focus on living as a writer and the pedagogy of teaching writing. This dual focus was important because by the time preservice teachers are in their preparation programs, they have "developed a sense of who they are as writers" (Morgan, 2010) through years of experience as students of writing. For those who have had positive experiences, they have developed a passion for writing while those who have had negative experiences do not enjoy writing and avoid it at all costs. The same can be said about the teaching of writing.

These experiences, as well as examining the literature devoted to self-efficacy, writing, and teaching writing, are all influencing how I am making sense of and interpreting the data.

Before proceeding, it should be noted that I have an existing personal relationship with Patsy, Daisy, Bella, and Eliza. In fact, two of the participants are my sisters. These 
close relationships provided me with deep knowledge and insight, however, I also had to ensure that the conclusions of the dissertation stemmed from the collected data. I had the pleasure of meeting Calvin through my professional contacts and through this study have had the opportunity to speak with him multiple times.

\section{Participant Selection}

The participants for this study were selected by purposeful sampling. Purposeful sampling is when "the researcher intentionally selects participants who have experience with the central phenomenon or the key concept being explored" (Creswell \& Plano Clark, 2007, p. 112). Purposeful sampling was employed to ensure that a range of teachers were included. The criteria for selecting the participants were that they: (a) were elementary classroom teachers during the 2017-2018 school year; (b) were teachers of writing during the 2017-2018 school year; (c) had at least two years of teaching experience; and (d) volunteered to participate.

In locating participants for this study, I relied on my extensive personal and professional network of colleagues, which included contacts with those associated with National Board Certification and the National Writing Project. From the contacts associated with National Board Certification and the National Writing Project, my goal was to identify elementary classroom teachers who had high levels of efficacy for writing and teaching writing. I also sought out elementary classroom teachers with whom I had personal knowledge about their writing experiences as well as teaching writing experiences. In addition, it was important to include a range of teachers representing diverse communities across the region and a range of years of experience.

The goal was to obtain five elementary classroom teachers for this study. A range of teachers who may have different levels of different forms of efficacy were chosen to 
better understand the manner in which the different types of efficacy manifest themselves. Once the teachers committed to participating in the study, a letter explaining the nature of the research study as well as an Informed Consent Form was provided to each participant (see Appendix A). All five participants completed the study and received a \$25 gift card. Two participants teach in the school district in which they attended as public school students. Both these participants have spent their entire career in this district. The remaining participants all teach in different school districts and do not teach in the districts in which they attended as students. Table 2 details the participants background information.

Table 2

Participant Background Information

\begin{tabular}{|c|c|c|c|c|c|c|c|}
\hline Participant & $\begin{array}{c}\text { Years of } \\
\text { Experience }\end{array}$ & $\begin{array}{c}\text { Highest } \\
\text { Educational } \\
\text { Level } \\
\end{array}$ & $\begin{array}{c}\text { Current } \\
\text { Grade } \\
\text { Level } \\
\end{array}$ & $\begin{array}{c}\text { Certifications } \\
\text { Earned }\end{array}$ & $\begin{array}{c}\text { Preparation } \\
\text { for teaching } \\
\text { writing } \\
\text { based on } \\
\text { pre-service } \\
\text { preparation }\end{array}$ & $\begin{array}{c}\text { Preparation } \\
\text { for teaching } \\
\text { writing } \\
\text { based on } \\
\text { inservice } \\
\text { preparation }\end{array}$ & $\begin{array}{c}\text { Experience } \\
\text { teaching } \\
\text { other } \\
\text { grade } \\
\text { levels } \\
\end{array}$ \\
\hline Patsy & 30 & Masters & $3^{\mathrm{rd}}$ & PK - 8 & Poor & Adequate & Yes \\
\hline Daisy & 8 & Masters & $3^{\mathrm{rd}}$ & $\begin{array}{c}\text { Elementary } \\
1-6\end{array}$ & Inadequate & Minimal & No \\
\hline Calvin & 8 & Masters Plus & $5^{\text {th }}$ & $\begin{array}{c}\text { Elementary } \\
\text { K - } 6 \\
\text { Middle School } \\
\text { Science }\end{array}$ & Very Good & Extensive & Yes \\
\hline Bella & 6 & Masters Plus & $2^{\text {nd }}$ & $\begin{array}{c}\text { Elementary } \\
\mathrm{K}-6 \\
\text { Special } \\
\text { Education } \mathrm{K}-12\end{array}$ & Poor & Minimal & Yes \\
\hline Eliza & 3 & Masters & $3^{\mathrm{rd}}$ & $\begin{array}{c}\text { Elementary } \\
\text { K - } 6 \\
\text { Middle School } \\
\text { English }\end{array}$ & Adequate & Adequate & Yes \\
\hline
\end{tabular}


Introductory Biographies. (The names of all participants have been changed to protect privacy.) To provide a sense of the participants, I introduce them here with short introductory biographies of their educational and professional backgrounds.

Patsy. Patsy is currently teaching in a rural western Maryland elementary school. During her 30-year career she has taught third grade for 25 years and a third/fourth grade split for five years. Patsy has always taught in the school district in which she is currently employed, and was her own district as a child. She is certified to teach pre-kindergarten through eighth grade.

Daisy. Daisy is currently teaching in a rural western Maryland elementary school and has spent her entire career teaching third grade in the same school district in which she attended as a child. She returned to college and earned her master's degree in elementary education after running her own business for 20 years. She is certified to teach grades one through six.

Calvin. Calvin is currently teaching in a West Virginia elementary school. He began his career as a long-term substitute teaching fourth grade, ninth grade, and special education. After teaching fourth grade for three years, he is currently looping to fifth grade for the first time. He holds a K-6 elementary certification and a 5-9 middle school science certification.

Bella. Bella is currently teaching in a rural elementary school in Virginia. For the past two years, she has been teaching second grade. Prior to that she spent two years teaching fifth grade. Bella has taught in different school districts as well as different states. She is certified to teach grades one through six and Special Education, K-12. 
Eliza. Eliza currently teaches in a suburban elementary school in central Maryland. She has taught third grade for the past two years. Prior to that she spent her first year teaching fifth grade. She holds a K-6 elementary certification and a 5-9 middle school English certification.

\section{Research Context}

This work took place in a mid-Atlantic Appalachian region in which the participants come from a range of different types of institutions and communities.

\section{Data Collection}

As my study examined the question of how the domain specific self-efficacies might manifest themselves in the teaching or writing, it necessitated a range of data sources. Each of the data sources provided insight about the participants and their experiences with writing and teaching writing. Prior to collecting any data each participant was given the opportunity to read and ask questions about the Consent Information Form. The purpose of the research and the procedures for securing the data was explained to each participant.

Once the participant signed and returned the Consent Information Form, the Background Information Form and Self-Efficacy Surveys were sent to each participant. A detailed description of the quantitative data sources follows.

\section{Data Source: Background Information Questionnaire}

To understand how efficacy may have been shaped over time for the participants, it was important to understand their background. The Background Information Form (Appendix B) was designed to acquire the following background information: (a) years of experience, (b) highest educational level, (c) current grade level, (d) certifications earned (e) preparation for teaching writing based on pre-service preparation, (f) preparation for 
teaching writing based on inservice professional development. The participants were also asked to describe their overall feelings about their writing experiences as well as their overall feelings about teaching writing.

\section{Data Source: Self-Efficacy Surveys}

Each participant completed a survey, which consisted of four different validated instruments (New General Self-Efficacy Scale, Self-Efficacy for Writing Scale, Teachers' Sense of Efficacy Scale, and Teacher Efficacy Scale for Writing). These surveys contained ten to fifteen questions each and use Likert scale ratings. There were 52 questions in total. The surveys provided me with a sense of each participant's perceived level of efficacy. An overview of each of the scales follows.

New General Self-Efficacy Scale (NGSES). The New General Self-Efficacy Scale (NGSES) was developed by Chen, Gully, \& Eden (2001). This unidimensional scale was used to capture an individual's belief of being capable or incapable of meeting task demands in a wide variety of situations (Chen, Gully, \& Eden, 2001). The NGSES is included in Appendix C.

Self-Efficacy for Writing Scale (SEWS). The Self-Efficacy for Writing Scale developed by Bruning, Dempsey, Kauffman, McKim, and Zumbrunn (2013) was utilized to ascertain participants' self-efficacy for writing. Bruning and his colleagues (2013) proposed three dimensions for a model of writing self-efficacy. One dimension of writing self-efficacy is "writers' beliefs about their abilities to generate ideas, their ideation" (Bruning, et al., 2013, p. 28). A second dimension is conventions which refer to a "set of generally accepted standards for expressing ideas in writing in a given language" (Bruning, et al., 2013, p. 28). A third dimension is self-efficacy for writing self-regulation 
which is "reflected in writers' confidence they can direct themselves successfully through writing's many dimensions and subtasks" (Zimmerman \& Bandura, 1994; Zimmerman \& Kitsantas, 2007 as cited in Bruning, et al., 2013, p. 29). "Self-regulatory skills are needed not only to generate productive ideas and writing strategies but also to manage the anxieties and emotions that can accompany writing” (Bruning, et al., 2013, p. 29). The SEWS is included in Appendix D.

Teachers' Sense of Efficacy Scale (TSES). The Teachers' Sense of Efficacy Scale (TSES), based on Bandura's scale, was developed by participants in a seminar on self-efficacy in teaching and learning in the College of Education at The Ohio State University (Tschannen-Moran \& Hoy, 2001). Three moderately correlated factors: efficacy in student engagement, efficacy in instructional practices, and efficacy in classroom management have consistently been identified. Efficacy in student engagement refers to teachers' beliefs about their abilities to interest students in what they are learning or being taught. Efficacy in instructional practices refers to teachers' beliefs about their abilities to implement various instructional strategies in the classroom. Efficacy in classroom management refers to teachers' beliefs about their abilities to manage behaviors and the daily routines of the classroom. These three constructs are assumed to exemplify teaching responsibilities. The TSES is included in Appendix E.

Teacher Efficacy Scale for Writing (TESW). Graham, Harris, Fink and MacArthur (2001) developed a 16-item modified version of Gibson and Dembo's (1984) Teacher Efficacy Scale that is used to measure teacher's self-efficacy for teaching writing. The items on the Teacher Efficacy Scale were reworded so that it was relevant to writing instruction at the elementary school level (Graham, et al., 2001). This instrument 
consists of two subscales; general teacher efficacy and personal teacher efficacy. Personal teaching efficacy (PTE) reflects teachers' beliefs about their ability to teach writing and affect change in their students while general teaching efficacy (GTE) reflects teachers' beliefs about limits in the effectiveness of teaching, especially in overcoming environmental factors such as the influence of home and family background (Graham et al., 2001). The TESW is included in Appendix F.

After the surveys were completed and returned to the researcher, each participant was contacted to schedule an interview lasting approximately one hour. A description of the narrative interview follows.

\section{Data Source: Narrative Interviews}

To develop a deeper understanding of how a teachers' sense of efficacy manifests itself in the teaching of writing, I returned to my proposed Integrated Model of Teacher Efficacy Beliefs in the Domain of Writing. Tschannen-Moran and her colleagues' (1998) model identifies sources of efficacy information as a potential component. These sources have happened in the past and they are not events that have an absolute meaning for everyone who has experienced them, rather, we know a similar event could have very different effects on different people. Thus, it is important to have each participant's retrospective understandings of what the significant events in their lives are and how they have made meaning of them. (Bruner, 1991). The interview provided the opportunity to dig deeply into the experiences of my participants. The interview questions were designed in a way to not specifically address the four sources of efficacy information as proposed in the Integrated Model of Teacher Efficacy Beliefs. It was my expectation that 
the participants' narratives would incorporate descriptions of how these four sources contributed to their efficacy.

Narrative interviews (See Appendix G) were conducted with five elementary classroom teachers. The narrative interviews provided participants with the space to identify significant moments in their life, to provide the context that made that moment significant, and to provide the researcher an explanation of how and why it is significant. The narrative interviews were used to capture the sources of efficacy information while writing and while teaching writing. Open-ended questions were asked that assisted the participants in telling their stories about their experiences in their own way and from their own perspective. The nature of the open-ended questions allowed me to see how the participant was conceptualizing these events in their lives. Per Kvale and Brinkmann (2009), "Narrative interviews center on the stories the subjects tell, on the plots and structures of their accounts" (p. 153). The goal was to capture rich and in-depth accounts about the individual participant's experiences and feelings while writing and while teaching writing. The researcher actively followed up on the participants' answers, seeking to clarify and extend the interview statements (Kvale \& Brinkmann, 2009). Each narrative interview was audio-recorded and transcribed verbatim. In addition to transcribing the interview, I kept notes in which I recorded the demeanor of the participants.

\section{Data Analysis}

The following section will explain how each of the data sources were analyzed. The analysis of the domain specific self-efficacy surveys will be discussed, followed by the analysis of the narrative interviews. 


\section{Self-Efficacy Surveys}

First and foremost, it is important to remember that "self-efficacy scales do not measure skill; they measure what individuals perceive they can do under varied circumstances whatever skills they possess or the particular skills required by the task" (Bandura, 1986b, p. 367), yet, the scales do provide a glimpse of self-efficacy beliefs. These scales were tools that were utilized to accomplish three things. First, these domain specific self-efficacy scales gave me the opportunity to compare individuals to one another. Might some trends emerge for the participants who share similar levels of efficacy? Second, they allowed me to look at all of these different levels of efficacy within an individual, which to my knowledge has not been done before. Third, they provided a backdrop that suggests further investigation. Because these different scales manifested themselves in different ways across the participants, it helped me key into how I should look at each narrative. What were the disparities that needed to be explained? Could the qualitative data help explain those disparities?

In relation to the first goal, comparing the individuals to one another, a standard score ( $z$-score) was calculated for all participants' overall self-efficacy scales. This decision was made so that each of the scales were on the same metric because without the standard score ( $z$-score), it is difficult to make comparisons. For each scale, the individual's responses to the statements were summed. The mean and standard deviation was then calculated. The individual scores for each scale was converted to a $z$-score, which is a standard score that "is comparable because they are standardized in units of standard deviations" (Salkind, 2011, p. 148). The calculations for converting the individual scores to a standard score ( $z$-score) are in Appendix H. After calculating the standard scores (z-scores), the level of efficacy was determined. High, moderate, and low levels of efficacy were based on the standard 
score ( $z$-score). A high designation is a $z$-score greater than or equal to one. A low designation is a $z$-score less than or equal to a negative one. A moderate designation is a $z$-score greater than a negative one and less than a positive one (see Appendix $\mathrm{H}$ ).

In relation to the second goal of examining efficacy levels within an individual, the mean scores of each subscale was utilized. The decision was made to use the mean scores for the subscales because there was no comparison of the subscales across the group but the scores were relative to each individual participant.

In relation to the third goal these domain specific self-efficacy scales provided a backdrop to help me make sense of the data and make connections between the various data sources.

New General Self-Efficacy (NGSES). This instrument consists of eight items that are rated on a 5-point scale ranging from strongly disagree to strongly agree. This scale is theory based, one-dimensional, internally consistent, and stable over time (Chen, et al., 2001).

Self-Efficacy for Writing Scale (SEWS). This 16-item scale represents a multifactor conceptualization of writing self-efficacy. Within the scale there are three subscales designed to represent idea generation (ideation), conventions, and writing selfregulation (Bruning et al., 2013). Participants rate their self-efficacy on a scale from no confidence to complete confidence. For each participant, a score was obtained for ideation by determining the mean score of the five survey items related to ideation. A score was obtained for conventions by determining the mean score of the five survey items related to conventions. A score was obtained for writing self-regulation by determining the mean score of the six items related to writing self-regulation 
Teachers' Sense of Efficacy Scale (TSES). This 12-item scale represents a multifactor conceptualization of teaching efficacy. Participants rate their teaching selfefficacy on a scale from nothing to a great deal. Three subscales within the TSES ask participants to report how capable they perceive themselves to be in engaging students, implementing instructional strategies, and managing the classroom. For each participant, a score was calculated for student engagement by determining the mean score of the four survey items related to student engagement. A mean score was obtained for the four survey items associated with instructional strategies and a mean score was obtained for the four survey items associated with classroom management.

Teacher Efficacy Scale for Writing (TESW). This scale consists of 16 items in which participants are asked to respond to a series of statements ranging from strongly disagree to strongly agree. There are two subscales within, personal teaching efficacy and general teaching efficacy. A score for personal teaching efficacy was calculated by determining the mean score of the ten survey items related to personal teaching efficacy. A score for general teaching efficacy was calculated by determining the mean score of the six survey items related to general teaching efficacy.

\section{Narrative Interview Analysis}

The theoretical framework that guided this study was built from TschannenMoran, Woolfolk Hoy and Hoy's (1998) Integrated Model of Teacher Self-Efficacy Beliefs. In this study, I applied the Tschannen-Moran et al. (1998) model to the context of writing instruction (See Figure 3). I proposed that there are two levels of the four sources of efficacy information that influence teachers' cognitive processing: those related to writing and those related to the teaching of writing. 
To analyze the data collected from the narrative interviews, I made the decision to utilize directed content analysis. A directed-content analysis approach uses existing theory or prior research findings to guide the initial approach to coding the data (Hsieh \& Shannon, 2005). My analysis began as I transcribed the narrative interviews. The interviews were transcribed verbatim. Next, the transcripts were printed and the data was coded to capture the previously identified sources of self-efficacy: mastery experiences, vicarious experiences, verbal persuasion, and physiological arousal based on existing research. Referring to my proposed model, I then coded these sources as to whether the participant was discussing an experience as a writer or an experience as a teacher of writing. After this was completed I read the transcripts again and was open to other codes that emerged. What emerged from the data were two distinct categories of experiences: those that were positive and those that were negative. Similarly, there were two distinct categories of context across participant's episodes: in-school setting and out-of-school setting. Coding at all stages was iterative; as data emerged that could not be coded by the initial coding scheme, new codes were added. See Appendix I for the Sources of SelfEfficacy as a Writer, which displays the coded theme, a definition of the coded theme, and an excerpt that provides an example of that theme. See Appendix $J$ for the Sources of Self-Efficacy as a Teacher of Writing, which displays the coded theme, a definition of the coded theme, and an excerpt that provides an example of that theme. Hsieh and Shannon (2005) posit, "The main strength of a directed approach to content analysis is that existing theory can be supported and extended" (p. 1283). 


\section{Summary}

To summarize Chapter 3, I described how the participants for the study were identified as well as the methods used for locating and contacting the individual participants. Five current elementary classroom teachers volunteered to participate in this study. The data, in the form of domain specific self-efficacy surveys and a narrative interview was collected and analyzed to provide insights into the participants. 


\section{Chapter 4: Participant Portraits}

\section{Overview}

The purpose of this study was to examine how self-efficacy manifests itself in the teaching of writing. The conceptual framework that guided this study was built from Tschannen-Moran, Woolfolk Hoy and Hoy's (1998) Integrated Model of Teacher SelfEfficacy Beliefs. In this study, I applied the Tschannen-Moran et al. (1998) model to the context of writing instruction (See Figure 3). I proposed a revision of the model to reflect two levels of the four sources of efficacy information: those related to writing and those related to the teaching of writing. This study was designed to understand how these functions manifest themselves in the teaching of writing. In this chapter I first highlight the scores of the domain specific self-efficacy scales and then provide an overall picture of the sources of efficacy. Next, I present a detailed portrait for each individual participant combining the results of the scales and the narrative interview. In many cases, the individual scores present questions that were in part - answered by the qualitative data.

\section{Domain Specific Self-Efficacy Scale Results}

By standardizing the scores for each self-efficacy scale, I could show how each of the participants scored compared to one another. Table 3, Participant's Standard Scores, puts forth the overall scores and the designation of high $(\mathrm{H})$, moderate $(\mathrm{M})$, or low $(\mathrm{L})$ levels of efficacy relative to one another. All scales, except for the New General SelfEfficacy Scale include subscales, which were not converted to a standard score because the participants were not being compared across the group. The scores for the subscale will be reported as the mean score. 
Table 3

Participant's Standard z-scores

\begin{tabular}{ccccc}
\hline & $\begin{array}{c}\text { New General } \\
\text { Self-Efficacy } \\
\text { Scale (NGSES) }\end{array}$ & $\begin{array}{c}\text { Self-Efficacy } \\
\text { for Writing } \\
\text { Scale (SEWS) }\end{array}$ & $\begin{array}{c}\text { Teachers' } \\
\text { Sense of } \\
\text { Efficacy Scale } \\
\text { (TSES) }\end{array}$ & $\begin{array}{c}\text { Teacher } \\
\text { Efficacy Scale } \\
\text { for Writing } \\
\text { (TESW) }\end{array}$ \\
\hline Patsy & $1.49(\mathrm{H})$ & $-.36(\mathrm{M})$ & $.77(\mathrm{M})$ & $-1.06(\mathrm{~L})$ \\
Eliza & $.34(\mathrm{M})$ & $1.00(\mathrm{H})$ & $-.80(\mathrm{M})$ & $.11(\mathrm{M})$ \\
Calvin & $.34(\mathrm{M})$ & $1.12(\mathrm{H})$ & $.41(\mathrm{M})$ & $1.88(\mathrm{H})$ \\
Bella & $-.80(\mathrm{M})$ & $-.16(\mathrm{M})$ & $1.13(\mathrm{H})$ & $-.47(\mathrm{M})$ \\
Daisy & $-1.37(\mathrm{~L})$ & $-1.60(\mathrm{~L})$ & $-1.52(\mathrm{~L})$ & $-.47(\mathrm{M})$ \\
\hline
\end{tabular}

Research has shown that self-efficacy is context and domain specific. However, before conducting this study, I thought these various domains may be somewhat related. For example, teaching and teaching writing do not seem like completely distinct domains. In designing the study, I thought I would see some consistency, particularly in the high levels. However, that was not the case because with efficacy the whole is not a sum of its parts. Different factors appeared to affect different elements and the qualitative methods help us understand why these differences may occur. First, I review each individual scale and the results.

\section{New General Self-Efficacy Scale (NGSES)}

The New General Self-Efficacy Scale is a unidimensional construct that is not related specifically to teaching but used to capture individuals' general beliefs about their capabilities to handle different situations in life. 
Table 4

New General Self-Efficacy Scale Scores

\begin{tabular}{cc}
\hline Participant & NGSES Standard Score \\
\hline Patsy & $1.49(\mathrm{H})$ \\
Eliza & $.34(\mathrm{M})$ \\
Calvin & $.34(\mathrm{M})$ \\
Bella & $-.80(\mathrm{M})$ \\
Daisy & $-1.37(\mathrm{~L})$ \\
\hline
\end{tabular}

As shown in Table 4, Patsy scored in the high range for general self-efficacy. General Self-Efficacy provides a backdrop, however, even Bandura himself has acknowledged that this is limited. Bandura $(1977,1997)$ argued that measuring general self-efficacy is too broad and narrow and should be task specific and because of this, the primary focus of this study will be on the three remaining scales.

\section{Self-Efficacy for Writing Scale (SEWS)}

According to Pajares and Johnson (1993), “writing self-efficacy beliefs are individuals' judgment of their competence in writing, specifically their judgment of their ability to write different writing tasks and of their possession of varying composition, usage, and mechanical skills" (p. 11). The Self-Efficacy Scale for Writing is comprised of three subscales: conventions, ideation, and self-regulation. Conventions consists of punctuation, capitalization, grammar, and spelling. Ideation refers to the ability to generate ideas and self-regulation refers to the ability to activate, monitor, and evaluate learning. 
Table 5

Self-Efficacy for Writing Scale Scores

\begin{tabular}{ccccc}
\hline & $\begin{array}{c}\text { Overall } \\
\text { SEWS } \\
\text { Standard } \\
\text { Score }\end{array}$ & $\begin{array}{c}\text { Conventions } \\
\text { Subscale } \\
\text { Mean Score }\end{array}$ & $\begin{array}{c}\text { Ideation } \\
\text { Subscale } \\
\text { Mean } \\
\text { Score }\end{array}$ & $\begin{array}{c}\text { Self-Regulation } \\
\text { Subscale Mean } \\
\text { Score }\end{array}$ \\
\hline Calvin & $1.12(\mathrm{H})$ & 98 & 84 & 78.3 \\
Eliza & $1.00(\mathrm{H})$ & 96 & 86 & 73.3 \\
Bella & $-.16(\mathrm{M})$ & 84 & 72 & 48.3 \\
Patsy & $-.36(\mathrm{M})$ & 90 & 54 & 50 \\
Daisy & $-1.60(\mathrm{~L})$ & 70 & 45.1 & 26.7 \\
\hline
\end{tabular}

As shown in Table 5, the mean scores of the subscales that comprise the SelfEfficacy for Writing Scale showed that all participants perceived themselves to be most efficacious with conventions and least efficacious with self-regulation.

Even though self-efficacy for writing has been examined mostly with $\mathrm{K}-16$ students, the data from this study is consistent with prior research. Prior research has shown that participants perceived themselves to be most efficacious in conventions and least efficacious in self-regulation (i.e., Bruning et al., 2013).

\section{Teachers' Sense of Efficacy Scale (TSES)}

Teacher efficacy is a subcategory of self-efficacy; it is referred to as "the teachers' belief in his or her capability to organize and execute courses of action required to successfully accomplish a specific teaching task in a particular context" (TschannenMoran et al., 1998, p. 233). The TSES scale is also comprised of three subscales: classroom management, student engagement, and instructional strategies. Table 6 displays the scores of the various subscales. 
Table 6

Teachers' Sense of Efficacy Scale Scores

\begin{tabular}{ccccc}
\hline & $\begin{array}{c}\text { Overall } \\
\text { TSES } \\
\text { Standard } \\
\text { Score }\end{array}$ & $\begin{array}{c}\text { Classroom } \\
\text { Management } \\
\text { Subscale } \\
\text { Mean Score }\end{array}$ & $\begin{array}{c}\text { Student } \\
\text { Engagement } \\
\text { Subscale } \\
\text { Mean Score }\end{array}$ & $\begin{array}{c}\text { Instructional } \\
\text { Strategies } \\
\text { Subscale } \\
\text { Mean Score }\end{array}$ \\
\hline Bella & $1.13(\mathrm{H})$ & 8.0 & 8.0 & 8.0 \\
Patsy & $.77(\mathrm{M})$ & 8.0 & 7.0 & 8.3 \\
Calvin & $.41(\mathrm{M})$ & 7.8 & 7.5 & 7.3 \\
Eliza & $-.80(\mathrm{M})$ & 7.3 & 6.8 & 6.0 \\
Daisy & $-1.52(\mathrm{~L})$ & 6.8 & 6.3 & 5.5 \\
\hline
\end{tabular}

Patsy has the most years of teaching experience in this study, followed by Calvin and Daisy. Bella is one of the least experienced teachers in this study, yet she has reported the highest level of teacher efficacy. Previous research has shown that more experienced teachers self-report a higher sense of teacher efficacy that less experienced teachers (i.e., Putman, 2012; Tschannen-Moran \& Woolfolk Hoy, 2007).

\section{Teacher Efficacy Scale for Writing (TESW)}

Teacher self-efficacy is specific to the content matter and context, and may vary among the various content areas (Bandura, 1997; Tschannen-Moran et al., 1998). Domain specific efficacy, such as teaching writing, refers to a teacher's perceived ability to teach writing. In the initial conceptualization of this study, I presumed that this construct was built from multiple domains: general self-efficacy, writing self-efficacy, and teacher selfefficacy. However, the results from this study did not indicate this to be true.

The Teacher Efficacy Scale for Writing is comprised of two subscales: personal teaching efficacy and general teaching efficacy. Personal teaching efficacy (PTE) reflects teachers' beliefs about their ability to teach writing and affect change in their students and general teaching efficacy (GTE) reflects teachers' beliefs about limits in the 
effectiveness of teaching, especially in overcoming environmental factors such as the influence of home and family background (Graham et al., 2001). Table 7 displays the scores of the two subscales.

Table 7

Teacher Efficacy Scale for Writing Scores

\begin{tabular}{cccc}
\hline Participant & $\begin{array}{c}\text { Overall TESW } \\
\text { Standard Score }\end{array}$ & $\begin{array}{c}\text { Personal Teaching Efficacy } \\
\text { Subscale Mean Score }\end{array}$ & $\begin{array}{c}\text { General Teaching Efficacy } \\
\text { Subscale Mean Score }\end{array}$ \\
\hline Calvin & $1.88(\mathrm{H})$ & 4.4 & 5.0 \\
Eliza & $.11(\mathrm{M})$ & 4.3 & 4.2 \\
Daisy & $-.47(\mathrm{M})$ & 4.0 & 4.3 \\
Bella & $-.47(\mathrm{M})$ & 3.8 & 4.7 \\
Patsy & $-1.06(\mathrm{~L})$ & 4.5 & 3.2 \\
\hline
\end{tabular}

Patsy, the participant with the most years of experience, and Eliza, the participant with the least years of experience, were more positive about their personal teaching efficacy. Calvin, Daisy, and Bella were more positive about their general teaching efficacy. Previous studies have found that teachers were more positive about their personal teaching efficacy than their general teaching efficacy (e.g., Graham, et al., 2001; Troia et al., 2011). This was not the case for all participants in this study.

In part, this part of the study was just to help us understand how these constructs come together in an individual and how they relate to one another within an individual. Can we tell something about it just by looking at these scales that are widely used? As is evident, there is no distinct patterns. These different ingredients manifest themselves differently for different individuals, which is why ultimately the qualitative piece is so important. 


\section{Narrative Interviews}

In addition to examining the various self-efficacy scales, I also conducted an interview with each of the participants to develop a deeper understanding of how a teachers' sense of efficacy manifests itself in the teaching of writing. In his seminal research, Bandura (1997) proposed four sources that contribute to the development of self-efficacy: mastery experiences, vicarious experiences, verbal persuasion, and physiological arousal. These four sources of self-efficacy information are the antecedents of individuals' beliefs about their self-efficacy (Bandura, 1997). The information alone is not enough - it must be cognitively processed.

Appendix K provides a breakdown of the number of excerpts that were coded for each source of efficacy information. As previously stated there are a range of factors that affect the extent to which someone feels efficacious. Efficacy manifests itself differently in different people. Narrative interviews provided insight into these individual manifestations as writers and teacher of writing. Tschannen-Moran and Hoy (2007) argue, "it is of both theoretical and practical importance to understand the sources teachers tap when making judgments about their capability for instruction” (p. 953).

To demonstrate the composite breakdown of all participant's sources of efficacy information as a writer and teacher of writing, I created a pie chart. Figure 4 helps us to see what sources the efficacy information comes from so that we can continue to enhance and develop the various sources. It should be noted that it is not the intensity of the source but how the individual interprets that source. 


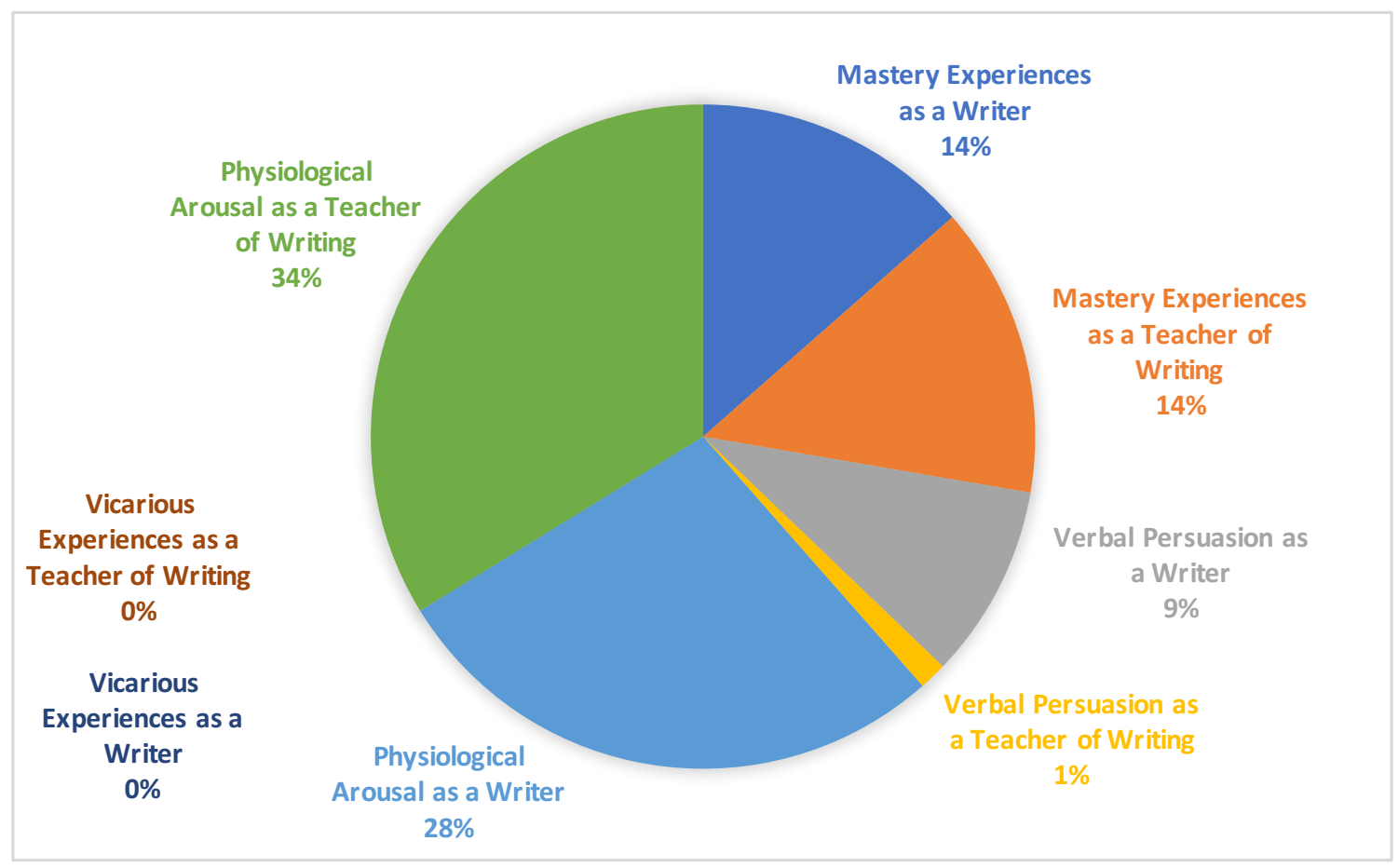

Figure 4. Composite Breakdown of all Participant's Sources of Self-Efficacy

\section{Mastery Experiences as a Writer and Teacher of Writing}

Mastery experiences are positive and negative personal experiences that can influence the perception of the ability to perform a task. Strong efficacy expectations are developed through repeated successes, while failures undermine and weaken selfefficacy.

Calvin and Eliza combined for the most mastery experiences as a writer. Bandura (1997) claimed that mastery experiences are the most influential source of efficacy information because these experiences provide the most authentic evidence of whether one can muster what it takes to succeed. Most of these episodes that were described by Calvin and Eliza were positive and occurred in out of school settings. Bandura (1997) contended, "Performance successes generally raise the beliefs of personal efficacy; repeated performance failures lower them, particularly if the failures occur early in the 
course of events and do not reflect lack of effort or adverse external circumstances" (p.81).

Calvin and Eliza also discussed the most mastery experiences as a teacher of writing as well. Most of the episodes they shared were positive. In addition, Calvin and Eliza were the only participants who scored in the high range on the Self-Efficacy for Writing Scale.

In addition to Calvin and Eliza combining for the most mastery experiences discussed as a writer and teacher of writing, they also scored the highest on the SelfEfficacy for Writing Scale and the Teacher Efficacy Scale for Writing. Because these mastery experiences were positive and the most influential source, it would make sense that they scored the highest on these two scales.

\section{Vicarious Experiences as a Writer and Teacher of Writing}

Vicarious experiences or modeling is another source of self-efficacy information. Seeing an individual, especially those whom we think of as role models, succeed can increase self-efficacy to do the same, however, seeing an individual fail can lower selfefficacy.

Vicarious experiences are generally weaker than direct ones (Bandura, 1997) however, they are an important source of efficacy. Interestingly, no excerpts from the narrative interviews were coded as vicarious experiences as a writer or a teacher of writing.

\section{Verbal Persuasion as a Writer and Teacher of Writing}

When individuals are verbally persuaded "that they possess the capabilities to master given tasks [they] are likely to mobilize greater effort and sustain it then if they 
harbor self-doubts and dwell on personal deficiencies when difficulties arise" (Bandura, 1997, p. 101). This source of efficacy is utilized most often because of its ease of use and it is readily available (Bandura, 1977). It is interesting to note that Tschannen-Moran and Woolfolk Hoy (2007) suggest that verbal persuasion is not a significant source of efficacy information for experienced teachers. This means that in order to boost selfefficacy for experienced teachers, it is going to require more than verbal persuasion; it may take a combination of verbal persuasion and a mastery experiences or verbal persuasion and a vicarious experience to make a measurable difference. Patsy, the participant with the most teaching experience did not share any episodes in which verbal persuasion either boosted or hindered her self-efficacy.

As a writer Bella received the most feedback from others. The episodes she spoke of were mostly negative experiences and occurred in an in-school setting. An example of negative verbal persuasion that Bella shared occurred in her teacher preparation program when she submitted an opinion paper about No Child Left Behind. She felt positive about the opinion piece, however, her instructor told her it was "too opinionated" and that she needed to "tone it down."

As a teacher of writing there were only two experiences coded as verbal persuasion, one was positive and the other was negative. The positive verbal persuasion was shared by Eliza, who had one of her students tell her that she was the best writing teacher ever and thanked her for her inspiration. The negative verbal persuasion was shared by Daisy who said when it is time for writing she hears her students say, "Oh no, not already" or "Oh, no not again!" 


\section{Physiological Arousal as a Writer and Teacher of Writing}

Bandura (1986a) suggests that self-efficacy beliefs about writing are shaped in part by emotional and physiological reaction to the task. These physiological indicators include stress levels, anxiety, moods, emotions, and physical reactions. Positive energy and emotions will likely increase self-efficacy, while negative energy and emotions will likely hinder performance.

Eliza had the most physiological reactions as a writer. The episodes she shared were mostly positive and occurred in an out of school setting. She shared statements such as, "Writing is just magic and it feels amazing to fill a blank piece of paper with my thoughts" and "I was just thinking about the joy of writing." Bella and Eliza had the most physiological or emotional reactions as teachers of writing. The negative and positive experiences were about equal. Bella shared both positive and negative physiological arousals such as, "I find it [writing] enjoyable, especially when it is the more creative pieces" and "I feel frustrated because I would like to believe that all kids can and will want to write, but that's usually not the case." Eliza also shared both positive and negative physiological arousals such as, "I was just excited to bring that [writing] into their life" and "I felt so boxed in and I couldn't do things with my kids. It's just that nothing felt natural."

Tschannen-Moran and her colleagues (1998), posits, "Self-perception of teaching competence is affected by all four sources identified by Bandura, but it is most directly influenced by mastery experiences and the physiological arousal associated with those experiences" (p. 229). The results of this study are consistent with that of TschannenMoran and her colleagues. 


\section{Individual Participant Portraits}

In this section I will discuss findings derived both from the various self-efficacy scales and the narrative interview. By bringing these forms of data together, it allows a more in-depth portrait of the participants.

When referring to the Self-Efficacy for Writing Scale, Teachers' Sense of Efficacy Scale, and the Teacher Efficacy Scale for Writing, I will be referring to the calculated standard score ( $z$-score), see Table 8 . These scores are relative to the other participants in the study. When referring to the subscales that comprise the Self-Efficacy for Writing Scale (conventions, ideation, and self-regulation), the Teachers' Sense of Efficacy Scale (student engagement, classroom management, and instructional strategies), and the Teacher Efficacy Scale for Writing (personal teaching efficacy and general teaching efficacy), I will be referring to the individual mean scores within the participant's own scale scores. These are presented, along with the $z$-scores, in each individual portrait. Subscales are listed in order of most to least efficacious.

There are a range of factors that affect the extent to which someone feels efficacious. In returning to the Proposed Integrated Model of Teacher Self-Efficacy Beliefs in the domain of Writing, these sources of efficacy include: mastery experiences, vicarious experiences, verbal persuasion, and physiological arousal both as writers and teachers of writing. Zimmerman (2000) argues, “... self-efficacy is assumed to be responsive to changes in personal context and outcomes, whether experienced directly, vicariously, verbally, or physiologically" (p. 88). The goal of this narrative is to provide insight into the experiences the participants described as writers and teachers of writing. 
Table 8

Summary of Individual Standard (z-scores) Overall Scores

\begin{tabular}{ccccc}
\hline & $\begin{array}{c}\text { New General } \\
\text { Self-Efficacy } \\
\text { Scale (NGSES) }\end{array}$ & $\begin{array}{c}\text { Self-Efficacy } \\
\text { for Writing } \\
\text { Scale (SEWS) }\end{array}$ & $\begin{array}{c}\text { Teachers' } \\
\text { Sense of } \\
\text { Efficacy Scale } \\
\text { (TSES) }\end{array}$ & $\begin{array}{c}\text { Teacher } \\
\text { Efficacy Scale } \\
\text { for Writing } \\
\text { (TESW) }\end{array}$ \\
\hline Patsy & $1.49(\mathrm{H})$ & $-.36(\mathrm{M})$ & $.77(\mathrm{M})$ & $-1.06(\mathrm{~L})$ \\
Eliza & $.34(\mathrm{M})$ & $1.00(\mathrm{H})$ & $-.80(\mathrm{M})$ & $.11(\mathrm{M})$ \\
Calvin & $.34(\mathrm{M})$ & $1.12(\mathrm{H})$ & $.41(\mathrm{M})$ & $1.88(\mathrm{H})$ \\
Bella & $-.80(\mathrm{M})$ & $-.16(\mathrm{M})$ & $1.13(\mathrm{H})$ & $-.47(\mathrm{M})$ \\
Daisy & $-1.37(\mathrm{~L})$ & $-1.60(\mathrm{~L})$ & $-1.52(\mathrm{~L})$ & $-.47(\mathrm{M})$ \\
\hline
\end{tabular}

\section{A Portrait of Patsy}

Patsy is a 30-year veteran teacher who has spent her entire career teaching in the same district that she attended as a student. Most of her teaching experience has been in third grade; however, she taught a third/fourth split as well. Patsy shared that her preservice training to teach writing was poor and her inservice training to teach writing has been minimal. During her teacher preparation program, there was not a course specific to writing offered. She had literacy courses but the focus was on reading and not writing. Her inservice training mostly consisted of the "one and done" type formats where there was no follow up or additional support offered. She also believes that her school "jumps on any new program that is out there that will increase test scores."

Figure 5 illustrates her scores on the domain specific self-efficacy scales and subscales. 


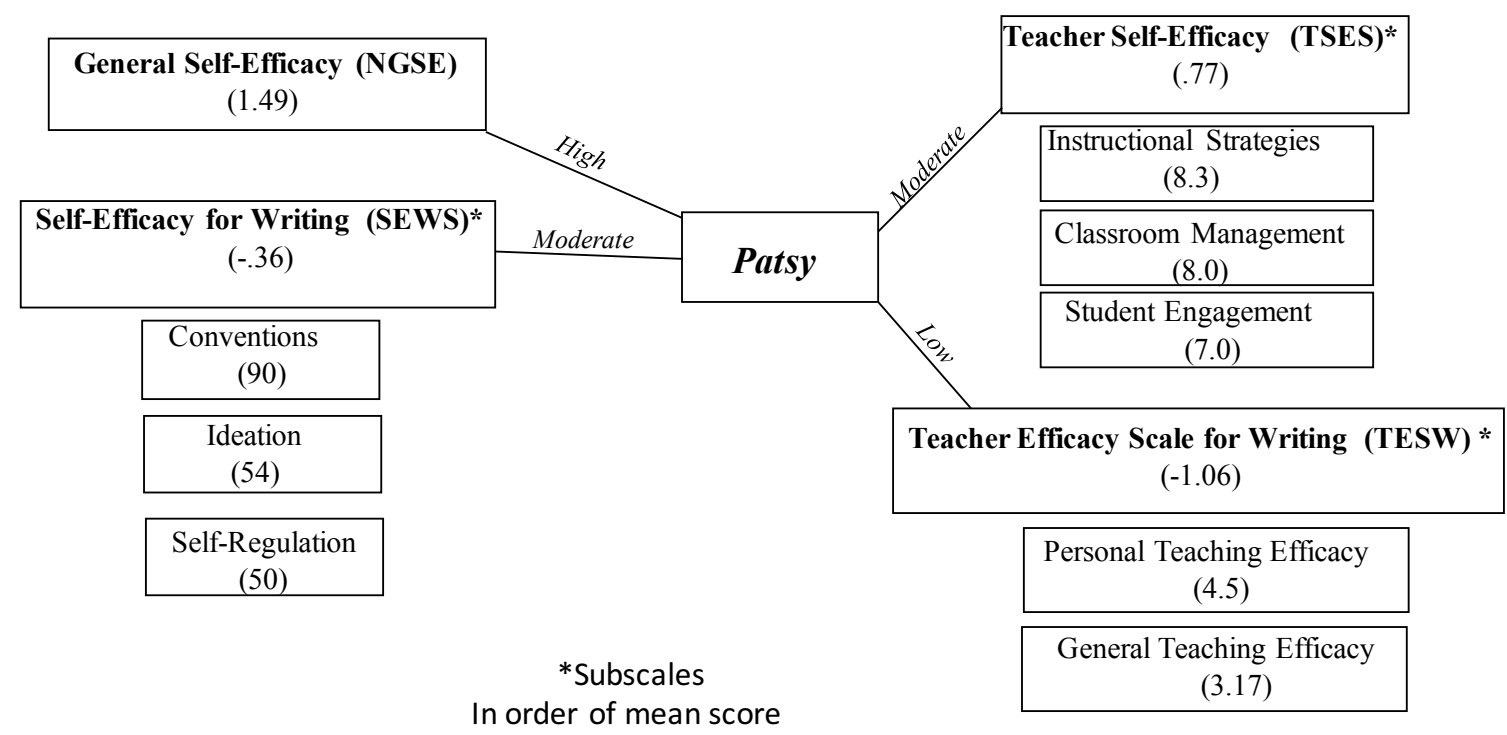

Figure 5. A Portrait of Patsy

As noted in Figure 5, Patsy scored in the high range for general self-efficacy. This means that Patsy perceives herself to have a high ability to perform successfully in a variety of situations. She perceives herself to have moderate levels of writing and teacher self-efficacy but a low level of teaching writing efficacy. Her many negative experiences as a writer may have contributed to her low self-efficacy as a teacher of writing.

In her interview, Patsy shared stories that provided evidence of her self-efficacy as a writer and a teacher of writing as she constructed narratives of her practice and interactions with students. Figure 6 illustrates Patsy's sources of efficacy as a writer and teacher of writing. 


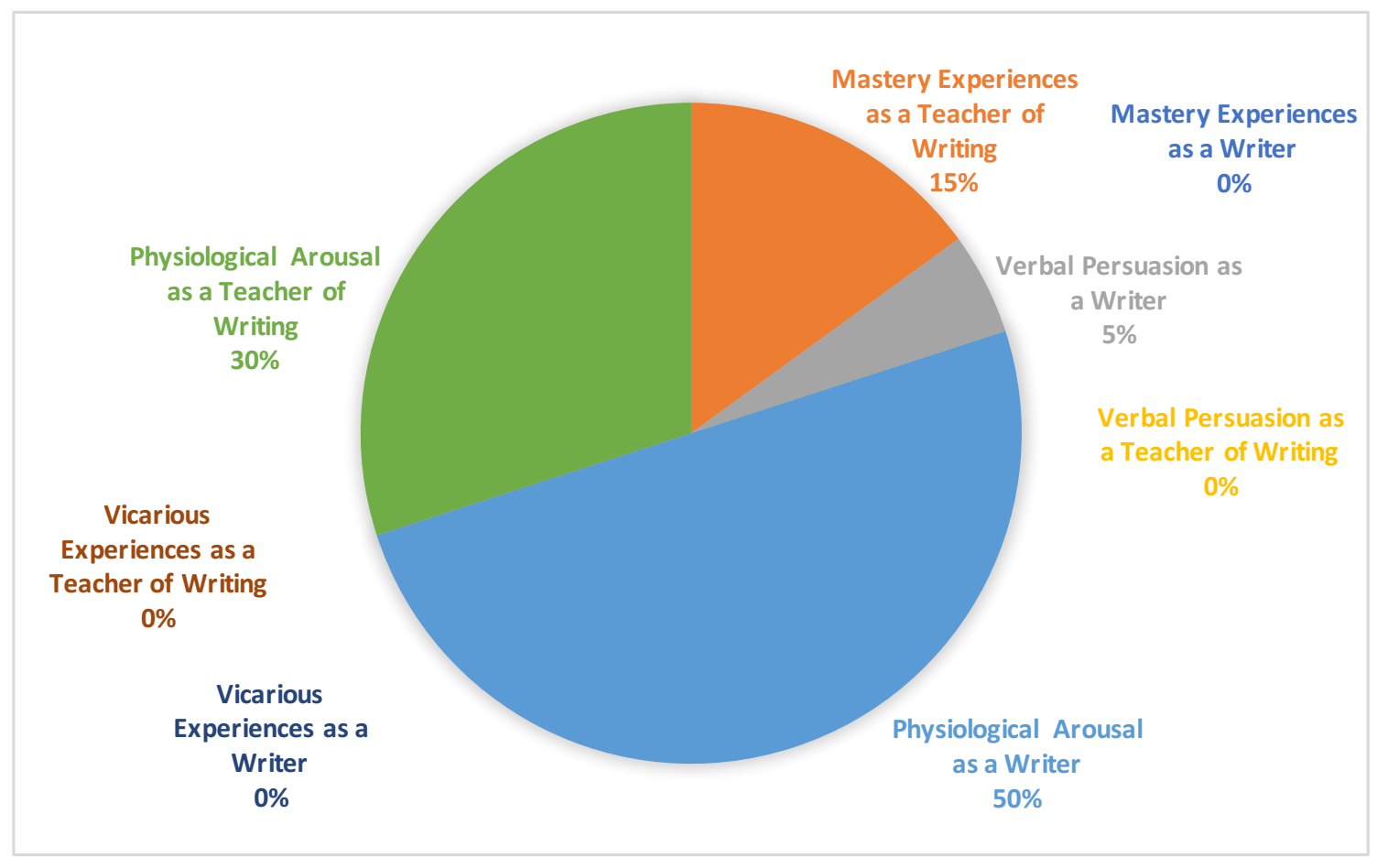

Figure 6. Patsy's Sources of Efficacy Information

As noted in Figure 6, the most influential source of efficacy for Patsy appears to be her physiological arousals both as a writer and a teacher of writing. As a writer, all the physiological reactions were negative episodes, with most of these episodes occurring in an in-school setting. The physiological reactions Patsy experienced as a teacher of writing were positive episodes. This would indicate that writing is strongly linked to her emotions. My interview notes captured a general lack of passion and enthusiasm as Patsy spoke about herself as a writer and teacher of writing.

Patsy has never enjoyed writing and sees it as a "daunting and laborious task." She named no mastery experiences and only one verbal persuasion related to writing. The verbal persuasion she spoke of did not occur until her college program. She recalled one of her instructors telling her, "You can do a great job on this paper." While this feedback 
was positive, it was vague. This verbal persuasion is likely to have been much more influential had it been specific to the task.

Patsy sees herself as a reader but not necessarily as a writer. In fact, she only writes out of necessity and for a specific purpose. She shared, for example, "I write notes to my kids about things I want done at home, notes to the special education teacher, and replies to parent's notes." Writing, for Patsy, is something that does not include, for example, e-mails and text messages. Cremin and Oliver (2016) conducted a literature review of empirical work from 1990 to 2015 on teachers as writers and concluded that "teachers have narrow conceptions of what counts as writing and being a writer. Many teachers appear to discount everyday writing or digital practices, and may not selfidentify as writers for this reason" (p. 23).

Patsy's perception of writing and who she is as a writer might have been influenced by the writing instruction she received as a K-12 student. She shared that in school writing consisted of "answering questions given by the teacher, filling in grammar worksheets, copying information from the encyclopedia, and doing book report after book report after book report." She recalled that during her years as a student, "grammar, punctuation, spelling, and mechanics" were the "center of attention." This focus on editing may have contributed to Patsy's relatively high mean score on the conventions subscale as compared with her mean scores for ideation and self-regulation. This narrow view of writing might also contribute to the fact that she did not recall any mastery experiences as a writer.

Moreover, the only source of efficacy that appears to have made an impact on Patsy as a writer were the physiological arousals, which were negative and occurred in an 
in-school setting (see Figure 6). A negative physiological arousal she shared was, "Writing essays and term papers were especially challenging and these assignments really stressed me out. I remember thinking, I can't do this!" There was always that "pit in my stomach!” These physiological reactions were typical of her experiences with writing and as a writer might have influenced the lack of efficacy she feels as a teacher of writing. Teachers need to write in order to become effective teachers of writing (Graves, 1983, The National Commission on Writing, 2003). Pasty's lack of efficacy as a writer has consequences for who she was able to become as a teacher of writing.

Patsy's experiences with writing seemed to influence her efficacy as a writer and may also have had implications for her self-efficacy for teaching writing which, according to the scales, was low. She defined writing as "a written form of communication. It is a way to express your thoughts and feelings in a sentence form." For Patsy, writing takes the form of essays or narratives rather than emails, text messages, or letters.

Ultimately Patsy's perceptions of writing not only influenced her experiences with writing, but also had implications for the teacher of writing she became. Patsy shared, "When I teach writing I spend a lot of time on how to construct a paragraph." She teaches her students about "topic sentences, supporting details, and conclusions." The focus for her writing instruction seems to be informed by her experiences with writing in school, where what she learned was that writing was focused on editing and conventions of the English language. As Fletcher and Portalupi (2001) posit, Researcher Dan Lortie has pointed out that about 75 percent of what we do as teachers has to do with what was done to us at the other 
side of the desk, when we were students. And few of us had teachers who truly listened to us when we were kids. Our thousands of school hours left an indelible imprint: we soaked up the classic school paradigm in which teachers talk and students listen" (p. 49).

Patsy also reported the physiological arousal of "feeling frustrated" when teaching writing. It is particularly disheartening for Patsy when her students "just aren't getting it" and "they have no confidence in their ability to succeed." Patsy attributes her physiological reaction to teaching writing to the fact that her students are "a lot like me and find writing to be a laborious task." Her lack of efficacy as a writer may make it difficult to support her students in developing efficacies as writers. Even when Patsy takes up practices with her students, such as writer's notebooks, which create spaces for students to live and develop as writers, she seems unable to move beyond rather teacherdirected and formulaic uses of this tool. Patsy's low efficacy as a writer limited how she might support her students in using the tools and processes of writers, which then influenced her perceptions of her students as writers and her efficacy as a teacher of writing.

However, Patsy did share some mastery experiences as a teacher of writing, even as she was unable to recount any mastery experiences as a writer. One of the mastery experiences she described was a writing lesson she has used and refined over the years. In conjunction with learning how to write a paragraph, Patsy has her students "publish an ABC Book." The students "choose their own topic and create their own book using the paragraph structure of topic sentence, supporting details, and conclusion." Patsy believes 
her students "enjoy" this because they "generally choose something they want to learn about or are interested in.”

To summarize, Patsy shared no mastery experiences, only one verbal persuasion, and mostly negative physiological arousals as a writer. Perhaps if Patsy would have encountered more positive experiences as a writer, her experiences as a teacher of writing would be different. In addition, because Patsy's experiences were not deeply developed enough or were too narrow in her scope to translate to more sophisticated writing instruction, she never took on the identify of a writer or teacher of writing. It appears her writing experiences contributed to her identity as a non-writer.

Patsy only shared a few mastery experiences, no verbal persuasions, and some physiological arousals associated with teaching writing. She is an experienced teacher who does not have multiple sources feeding her self-efficacy. Had there been multiple sources feeding her efficacy, perhaps she would feel more efficacious to teach writing.

In addition, the literature suggests that more experienced teachers self-report a higher sense of teacher efficacy that less experienced teachers (i.e., Putman, 2012; Tschannen-Moran \& Woolfolk Hoy, 2007), however, the findings of this study did not demonstrate this relationship. Although Patsy has the most years of teaching experience, the only measure she had in the high range was general self-efficacy, not writing, teaching, or teaching writing. This suggests that it is not only the experience of teaching that contributes to self-efficacy, but the nature of the experience. Perhaps Teaching Writing Self-Efficacy requires more than teaching experience, but writing experience as well. 
It should be noted that efficacy tends to be resistant to change for experienced teachers (Tschannen-Moran, et al.,1998). There is a fear of failure and for Patsy, that fear may outweigh the benefits of change. Bandura (1997) postulated that making positive changes in established efficacy beliefs involves "compelling feedback that forcefully disputes the preexisting disbelief in one's capabilities" (p. 82).

\section{A Portrait of Daisy}

Daisy is a third-grade teacher who has been teaching in the same district at the same school for eight years. She, unlike the other participants, was a mid-life career changer. Daisy feels as though her preservice training to teaching writing was inadequate and her inservice training has been minimal. Figure 7 illustrates her scores on the domain specific self-efficacy scales and subscales.

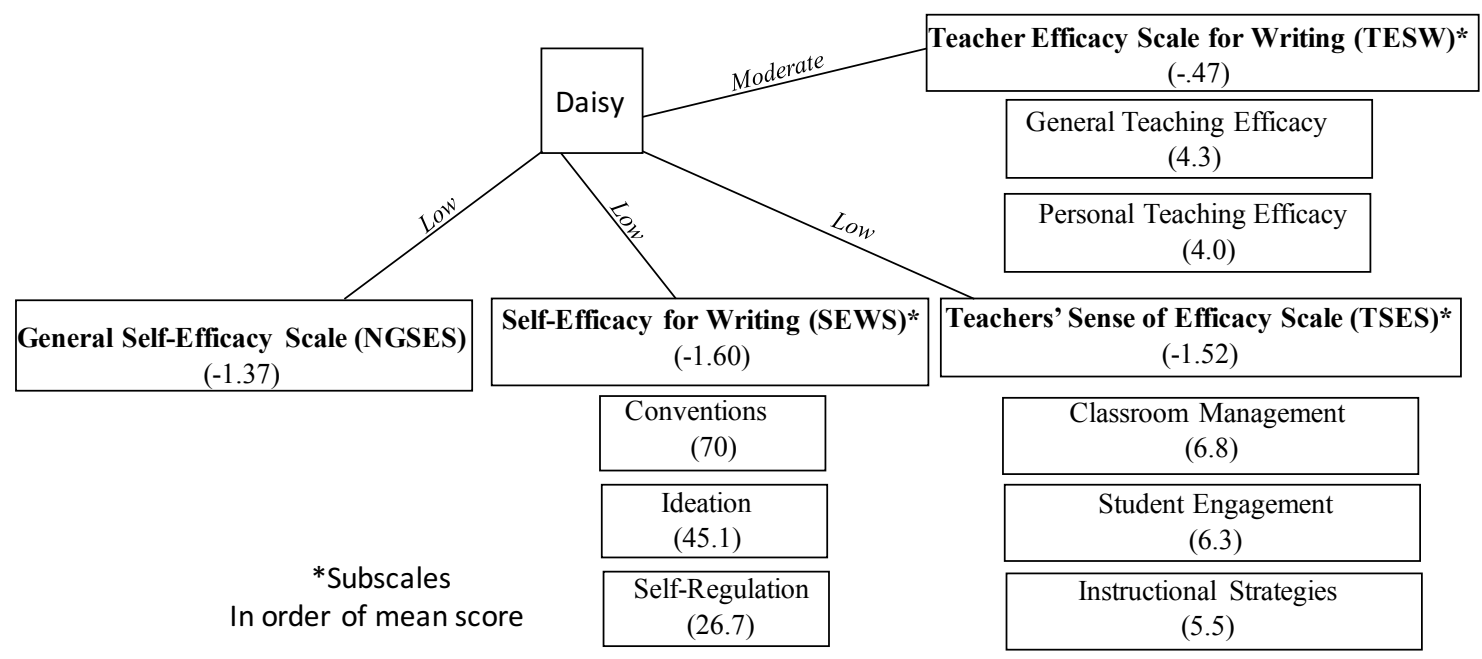

Figure 7. A Portrait of Daisy 
As noted in Figure 7, Daisy consistently scored in low range on all self-efficacy scales except for the Self-Efficacy for Teaching Writing Scale, where she scored in the moderate range. In addition, her mean scores on the subscales were consistently lower than the other participants, except for the Self-efficacy for Teaching Writing subscales. Daisy has a negative perception of herself as a writer. She shared comments like, "I feel like I am a poor writer...well maybe not poor but not a good one;" "Writing is difficult for me;" and "I am not confident in my ability." These are examples of negative physiological arousals associated with her experiences as a writer.

Daisy shared stories that provided evidence of her self-efficacy as a writer and a teacher of writing as she constructed narratives of her practice and interactions with students. Figure 8 illustrates Daisy's sources of efficacy as a writer and teacher of writing.

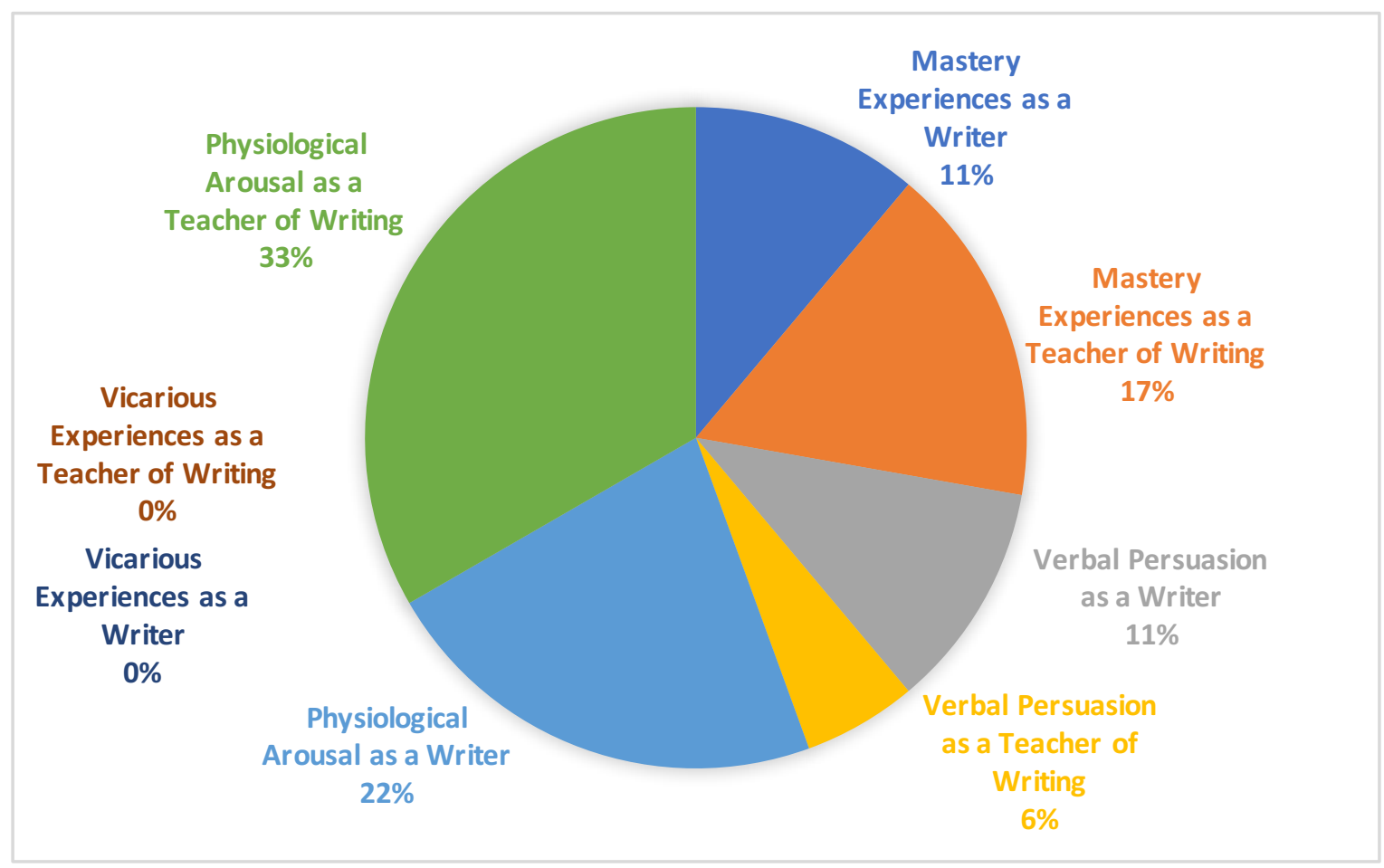

Figure 8. Daisy's Sources of Efficacy Information 
As noted in Figure 8, the most influential source of efficacy for Daisy appears to be her physiological arousals both as a writer and a teacher of writing. As a writer, all the physiological reactions were negative episodes, with most of these episodes occurring in school settings. An example of the physiological arousal she shared was, "I felt anxious and stressed just thinking about the writing assignment" and "all of the red ink on the page made me feel like a failure and hate writing." As a teacher of writing, Daisy experienced more negative physiological arousals than positive ones. A negative physiological arousal she shared was, "It is kind of scary teaching writing because I want to make sure I am teaching it right.” My interview notes captured Daisy need for reassurances that she was answering the questions correctly as she would ask, "Do you know what I mean?"

Daisy, like Patsy sees herself as a reader but not necessarily a writer. Daisy shared that she does not believe as though she was ever "taught how to write" or "how to enjoy writing." She does not remember "writing ever being encouraged" nor did it ever "appear important to her teachers." The "writing time" she experienced in school was all about grammar and mechanics. In part, this may explain why Daisy's mean score on the subscale of conventions was much higher compared to her mean scores for ideation and self-regulation. Moreover, this narrow view of writing might also contribute to the fact that she recalled very few mastery experiences as a writer. One mastery experience she did recall was a paper she wrote in high school. She shared that when she turned it in to her teacher, she felt "pretty good" (physiological arousal) about the paper. However, when it was returned it was covered with "red ink comments everywhere" and she was "shocked" because she had felt so good about the paper. What she perceived as a mastery 
experience on her part was diminished by the comments she received from her teacher, thus impacting her self-efficacy in a negative way.

Daisy struggled to develop and organize her thoughts as she created written pieces, she felt (physiological arousal) as though her writing was never "good enough" and just assumed she would "get a bad grade." She questioned her ability as a writer and her lack of efficacious beliefs may have contributed to her seeming lack of success with writing. Linnenbrink and Pintrich (2003) contends, when students have a low sense of efficacy they often tend to focus on the outcome, such as grades, rather than developing and enhancing their learning. Daisy recalled an episode in her certification program where she had to "prepare a report that detailed the learning of a student in the reading clinic." In recalling the experience, she admitted that she was "focused on getting a good grade" and perceived that the grade would determine whether she felt efficacious as a writer or not. In fact, Daisy received "an A" which "boosted my confidence and for once I actually felt that I had succeeded as a writer." Ultimately, the focus was not on her learning (internal) but on the outcome (external).

Based on her experiences with writing, it is not surprising that Daisy does not see herself as a writer. In fact, her most influential source of efficacy as a writer were the physiological episodes she experienced, which were all negative. A negative physiological arousal Daisy shared was, "writing makes me feel anxious and my biggest fear is that I will sound like I don't know what I am talking about.” These negative emotions occurred mostly in school settings and most likely contributed to her negative attitudes towards writing as well as her low writing self-efficacy. According to Pajares, Johnson, and Usher (2007), "When students experience negative thoughts and fears about 
their capabilities, those affective reactions can lower self-efficacy perceptions and trigger additional stress and agitation that help ensure the inadequate performance feared" ( $p$. 107). Like Patsy, Daisy's lack of self-efficacy as a writer had consequences for who she was able to become as a teacher of writing. As Routman (2005) posits, "The simple fact is we have to see ourselves as writers if we are to teach writing well” (p. 35).

As a teacher of writing, Daisy believes she can and does "teach her students the basics." The basics for Daisy are "grammar, punctuation, mechanics, and spelling." Again, this may explain her high conventions sub-scale score. She admitted that there are "better ways to approach teaching writing" but she finds herself focusing on the "way in which she was taught," a legacy of her apprenticeship of observation. Even though she knows there are better ways to approach teaching writing, she reverts to what is comfortable. She does not feel efficacious enough to "test the waters" and implement a new method or strategy. Her affective responses to teaching writing lead to "frustration" with her teaching and her students, who she perceives, "just don't like to write." It is possible that Daisy's feelings of inadequacy as a teacher of writing may lead to her setting up "roadblocks to stifle the natural and enduring reasons for writing," and contribute to her complaints "that [her] students don't want to write" (Calkins, 1986, p. 4). In fact, Daisy shared that when it is "writing time" she is disheartened to hear (verbal persuasion), "Oh no not again! Writing is so boring!" from her students. Their lack of enthusiasm for writing may have further influenced her self-efficacy for teaching writing contributing to a vicious and negative self-fulfilling prophecy.

However, despite her seeming disillusionment as a teacher of writing, Daisy also shared some positive mastery experiences as a teacher of writing. She described a lesson 
that she has used multiple times to teach descriptive writing. She asked her students to describe their favorite pet. If they did not have their own pet, they could describe their grandparent's or friend's pet. This was a mastery experience for her because she perceived the lesson as being successful because all her students produced the same product. Part of the success that she was experiencing was because she had control over the topic, the graphic organizer, and the publishing of the final product; the students had no voice in the assignment. Bandura (1997) suggests that teachers who are lacking selfefficacy often embrace a custodial view of education. Thus, Daisy's need for control over this assignment might be attributed to her low self-efficacy as a teacher of writing. She does not feel she can relinquish control because she does not believe she can be responsive to her students. Therefore, she reverts to the pedagogies she encountered as a K-12 student, rather than grapple with the uncertainty of adopting other approaches to teaching writing.

Although Daisy attends professional development both within and outside of her district, she does not feel efficacious enough to implement her new learning. Although Daisy has learned other methods for teaching writing, she always returns to the way she was taught because it is comfortable and what she knows. As Katie Wood Ray (1999) suggest, "It seems we [teachers] have to spend a lot of time fighting against what our own educational histories have taught us to believe" (p. 11). These long "apprenticeship of observation" (Lortie, 1975) prove challenging for teachers to overcome and a lack of selfefficacy may contribute to the fact that many teachers teach their students as they were taught. Daisy's low self-efficacy led her to putting writing "on the back burner" and only getting to it if she had time. 
There is also research to indicate that once individuals develop a low sense of efficacy in a particular domain, they often discount their successes rather than change their self-belief (Schunk, 1991; Zimmerman 2000). Therefore, it is not surprising that Daisy did not develop efficacious beliefs about who she might be as a writer and teacher of writing, as her experiences with writing were most often perceived as negative.

For Patsy and Daisy, the focus on prescribed essential skills impacted their selfefficacy as writers and teachers of writing. They had very few positive experiences as writers and therefore did not develop a passion or joy for writing. Their lack of efficacy as writers makes it difficult to support their students in developing efficacies as writers.

This raises interesting questions about preparing and sustaining efficacious teachers. If Patsy and Daisy would have had the opportunity during their teacher preparation program to take a course that specifically focused on writing, would they perceive themselves to be more efficacious as writers and teachers of writing? The same can be said about the professional development in which they engage. Would they feel more efficacious as writers and teachers of writing if the professional development had been ongoing, longitudinal, and authentic and not a "one and done" format?

\section{A Portrait of Calvin}

Calvin is a fifth-grade teacher who has been teaching for eight years. He is the only participant who feels as though his preservice training to teaching writing was very good and his inservice training has been extensive. Figure 9 illustrates the various scores on the domain specific self-efficacy scales and subscales. 


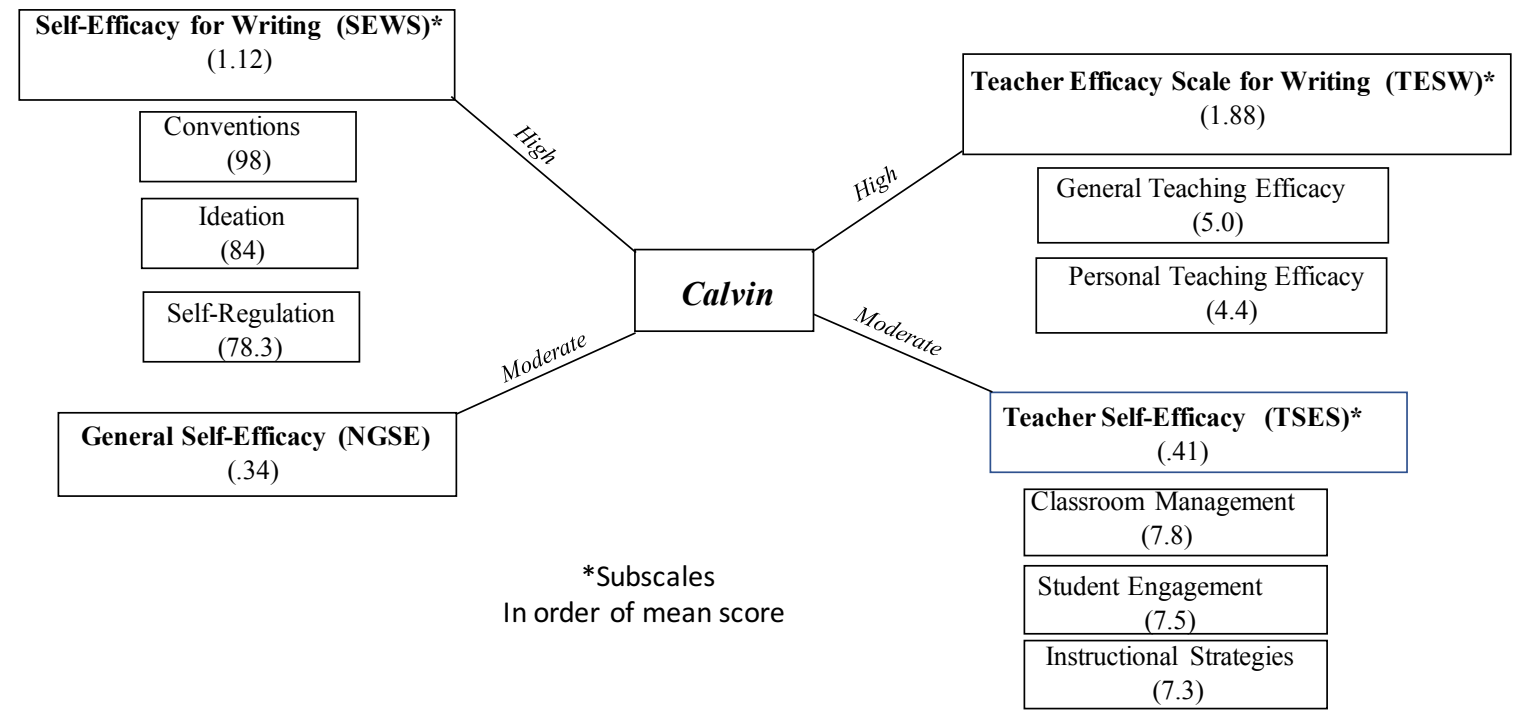

Figure 9. A Portrait of Calvin

As noted in Figure 9, Calvin scored in the moderate range in general self-efficacy and teaching self-efficacy and within the high range in writing self-efficacy and teaching writing self-efficacy. Calvin is the only participant who scored in the high range for both writing and teaching writing self-efficacy. Although Calvin shared some negative episodes while working on his National Board certification, unlike Patsy and Daisy, the majority of his experiences with writing and teaching writing have been positive. Calvin has a broader view of writing stating:

In technical terms, writing is a way for us to represent our language in a visual form. It is something that we can see, feel, and hold. However, it's more than just a tactile representation of language.

Writing is a way for people to express their feelings, emotions, and ideas in a way that it can be shared and saved through generations. Writing has become sort of an art form over the years as well, with calligraphy, script, graffiti, and so on. 
For Calvin, writing is not about conventions but a way to express feelings, emotions, and ideas. It was interesting that Calvin tapped into the five senses in his definition of writing, because it is through our senses that we experience the world around us. So writing, for Calvin, goes beyond success in the classroom. Writing, for Calvin, is about experiencing and understanding the world. His definition also shows the value and importance he places on the written word in that writing is something that can be shared and passed down through generations.

In his interview, Calvin shared stories that provided evidence of his self-efficacy as a writer and a teacher of writing as he constructed narratives of his practice and interactions with students. Figure 10 illustrates Calvin's sources of efficacy as a writer and a teacher of writing.

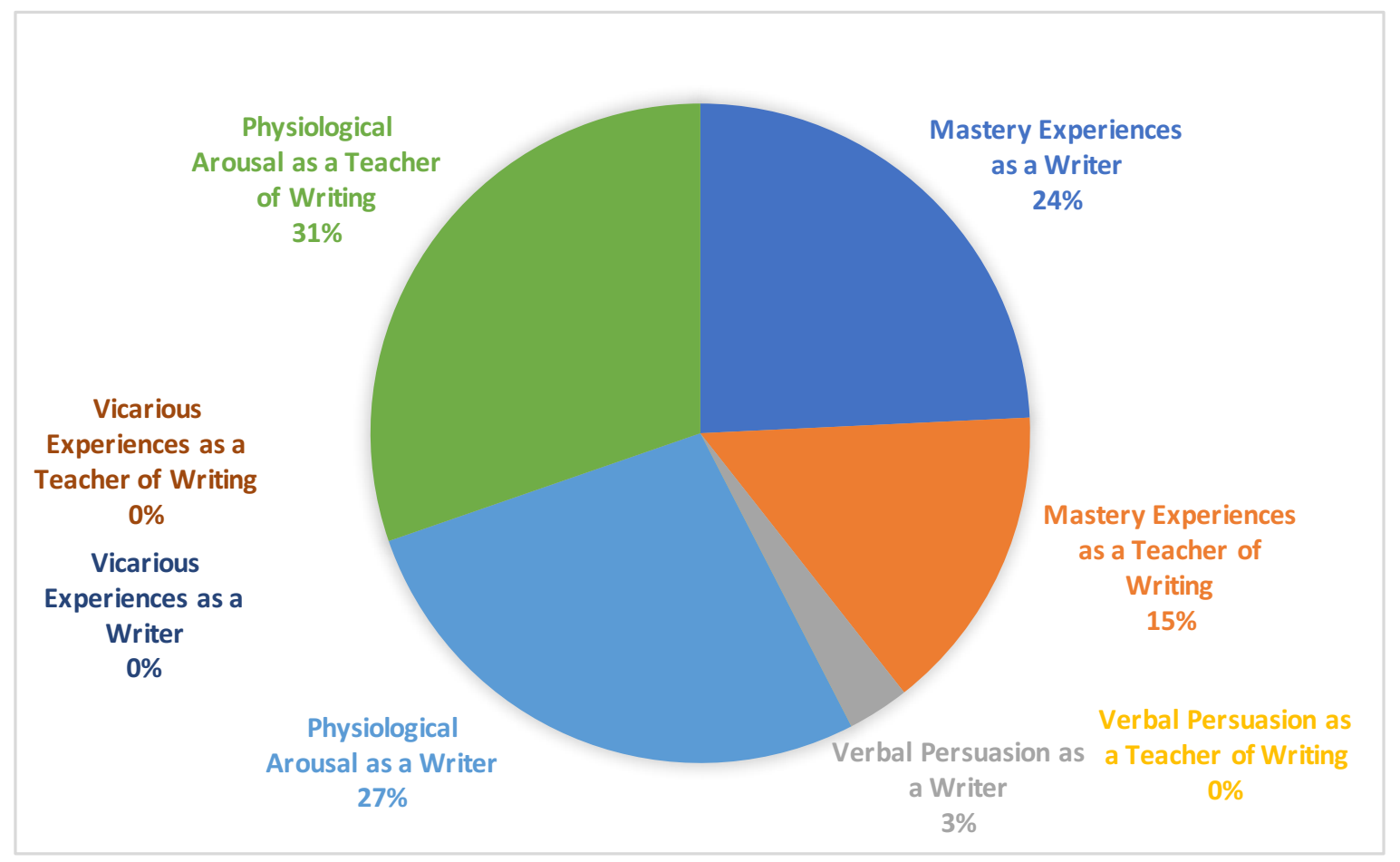

Figure 10. Calvin's Sources of Efficacy Informatio 
As noted in Figure 10, the most influential source of efficacy for Calvin appears to his physiological arousals as a writer and teacher of writing. As a writer, most of these episodes were positive and they occurred both in and out of the school setting. A physiological arousal Calvin shared as a writer was, "I have always felt pretty proud of my work." A physiological arousal Calvin shared as a teacher of writing was, "When the whole writing process is finished it's something that not only I, as a teacher, am proud of but also I like seeing my students proud of their work as well.” My interview notes captured Calvin as confident and self-assured when sharing his thoughts and experiences as a writer and teacher of writing.

Unlike Patsy and Daisy, Calvin sees himself as a writer, has always enjoyed writing (physiological arousal), and is confident (physiological arousal) with his work. As a writer, the most influential sources of efficacy information appear to be mastery experiences and physiological arousals. A mastery experience that he shared as a writer occurred when he was a student in middle and high school. He had some of his work published in sixth grade and in high school he ended up winning a writing context. He said, "I was very confident (physiological arousal) in my work; however, I would not have been as confident in my writing had I not had a few key teachers along the way." He stated, "I had teachers that really like helped to boost my confidence in writing. They gave me feedback (verbal persuasion) that improved my writing." As Routman (2005) suggest, "It takes so little effort to turn a student into a writer: a human connection, teacher modeling, supportive conversations before writing begins, an appreciation of the student's efforts, sincere affirmation, real writing for a purpose, and a reader that the 
student values" (p. 21). Those teachers positioned him to "feel stronger and more confident" (physiological arousal) in his writing and it "became easier" for him."

As a writer, the only time he recalled experiencing a negative physiological arousal was writing for his National Board certification. His affective state of "frustration" was very much the center of what he described when discussing the National Board certification process. He described it as "challenging," "the most stressful thing I have ever done," "definitely some built up hard feelings," and "I was pretty upset." He stated, "I had to relearn how to write for that process. I was not able to just sit down and write but had to rein it in and really narrow my thoughts down and be concise with them because there was a page limit." Although this was one of the "biggest challenges" he has faced he knew he could "succeed." Perhaps because of the positive early experiences that Calvin had with writing, he was able to feel successful even though he was facing a challenging task.

Overall Calvin believes his experiences with writing have been "good" and in the end, he feels "pretty proud of the work" he has submitted. He feels as though writing is "definitely a strength." Perhaps the many positive influential experiences have indeed allowed Calvin to perceive himself as an efficacious writer.

Calvin recalled various physiological arousals associated with teaching writing such as, "It [writing] was not the easiest thing to do when I started my teaching career." He attributes this to the fact that he was "so confident" with his own writing ability. He believes "it is hard to teach" something that you are good at because you "have to break it down to simple building blocks" and that was "really hard" for him at the beginning. He could not recall a time when someone had to "break down" the process of writing for him 
personally. At the beginning of his teaching career, he admits to not being "very empathic” to his students. He recalls thinking, “...why can't you read? I read books all the time. Why can't you write? I write all the time. This is not hard." It took some time before he learned to put himself in his student's shoes. He also shared that it is important to him to "get his students to love (physiological arousal) the process first before worrying about what they are doing with the process." He believes that it is important for his students to have a choice in the topics they write about. He stated, "This allows them to take ownership and have a stake in their writing."

Calvin finds it hard to "teach kids to take what they are thinking and put it on paper." He talked about the difficulties of having his students get their thoughts down and develop their ideas before worrying about the conventions of their writing. He shared that many times his students are more worried about correct spelling, grammar, and punctuation than they are about the content. Even though Calvin knows the focus of writing need to be on the process, the students in his classroom have not internalized this and continue to focus on the conventions of writing.

It was interesting that Calvin spent some time talking about writing lessons that were not as successful as he had hoped. He did not question his student's ability but rather reflected on himself and what he would have done differently to make the lesson successful. For example, at the end of last year he asked his students to write a letter to him about the things they liked about their classroom and the things they would change. He was shocked to get a "bunch of lists." He readily admitted to "not doing a whole lot of letter writing" and that was his fault and something that "I should have put more focus on before expecting my students to just do it." Instead of blaming external factors, 
Calvin looked internally at himself and what he could have done to make this a mastery experience not only for himself but his students as well.

To summarize, Calvin shared numerous mastery experiences, only one verbal persuasion, and mostly positive physiological arousals as a writer. Although there were challenges specific to his National Board certification, he always knew that he could “succeed." Based on Calvin's experiences with writing, it is not surprising that he sees himself as a writer. From early on he had experiences that empowered him and because of this he was able to succeed even when faced with a challenge. Calvin's experiences were deeply developed and broad in scope and he was able to translate this to a more sophisticated writing instruction.

He shared some mastery experiences, no verbal persuasions, and numerous physiological arousals associated with teaching writing. Ultimately Calvin's perceptions of writing not only influenced his experiences with writing, but also had implications for the teacher of writing he became.

\section{A Portrait of Bella}

Bella is a second-grade classroom teacher who has experience teaching other grade levels in different school districts in different states. She believes her preservice training to teach writing was poor and her inservice training to teach writing has been minimal. She shared that there was not a specific course devoted to teaching writing in her teacher preparation program. Figure 11 illustrates her scores on the domain specific self-efficacy scales and subscales. 


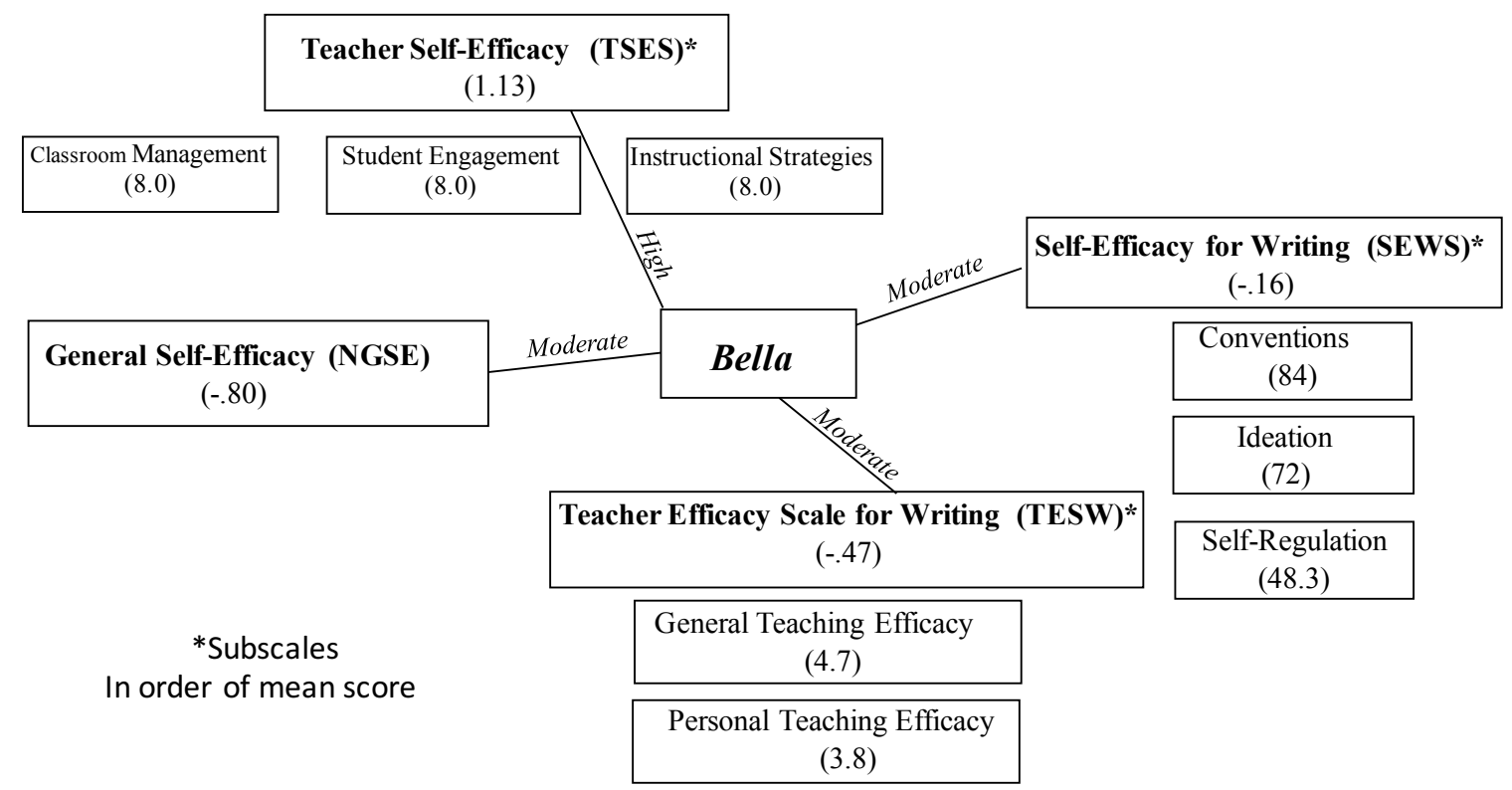

Figure 11. A Portrait of Bella

As noted in Figure 11, Bella scored in the moderate range for general selfefficacy, writing self- efficacy, and teaching writing self-efficacy. She scored in the high range for teaching self-efficacy. Bella perceives herself to be equally efficacious across the constructs of classroom management, student engagement, and instructional strategies. This has not been the case in previous research, as previous research has shown the mean score to be higher on one construct or the other. Her conventions and ideation mean scores are relatively close, while self-regulation is not. Perhaps, as a writer Bella attends to conventions and ideation more so than self-regulation. Her score on the general teaching self-efficacy subscale indicates that she is highly positive concerning her self-efficacy about the extent to which students can be taught given environmental factors, such as home environment and family.

During her interview, Bella shared stories that provided evidence of her selfefficacy as a writer and a teacher of writing as she constructed narratives of her practice 
and interactions with students. Figure 12 illustrates Bella's sources of efficacy as a writer and teacher of writing.

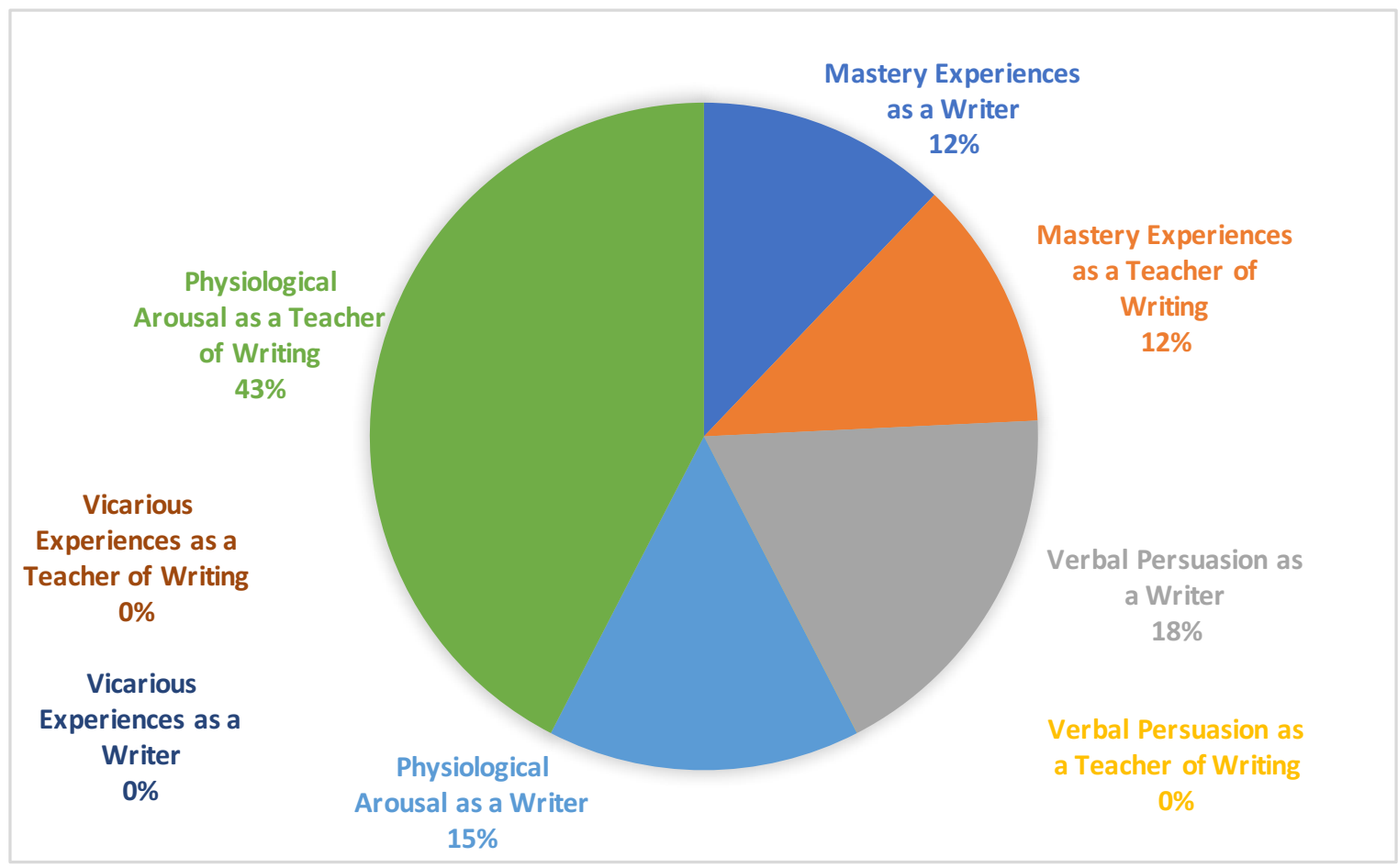

Figure 12. Bella's Sources of Efficacy Information

As noted in Figure 12, the most influential source of efficacy for Bella, as a writer, appears to be verbal persuasion followed closely by physiological arousals and mastery experiences. As a writer, the verbal persuasions were mostly negative and occurred in school settings. An example of a verbal persuasion Bella shared was, "I felt very confident when I submitted my assignment and then when it was returned there were many negative comments on the paper that really shocked me and made me question what I had written." What Bella perceived as a mastery experience on her part was diminished by the comments she received from her teacher, thus impacting her selfefficacy in a negative way. 
However, the physiological arousals she shared were mostly positive and in school settings. A physiological arousal Bella shared was, "I was always so excited to write. It was the best part of the day!" Although she had competing sources of efficacy, she has always perceived herself as a writer. As a teacher of writing, Bella experienced more negative physiological arousals than positive ones. A physiological arousal Bella shared as a teacher of writing was, "It made me feel kind of downhearted because I'm thinking now how can I get that into all the other 18 kids in here."

Like Calvin, Bella has always enjoyed writing and believes that it is something that comes naturally to her. It is "easy" for her to just sit down and write; the ideas flow. Because she was not a "good student" in school in mathematics, writing was always the "best part of the day."

Like Calvin, Bella entered and won some writing competitions in school. This is an example of a positive mastery experience as a writer. It was not until her teacher preparation that Bella felt less efficacious as a writer. In one of her English courses, Bella was asked to write an opinion piece about a topic she found interesting. She chose to write about the No Child Left Behind Act. She felt "really good" (physiological arousal) and was "confident" about her piece because she was so passionate about the topic. She got "knocked down a few levels" when the instructor told her that her writing was "too opinioned" and that her piece needed to be "toned down" (verbal persuasion). While sharing this episode, I noted that Bella appeared to be very surprised and offended by this instructor's comments. However, she was fortunate in that the instructor positioned her to feel efficacious enough to produce what was expected. She recalled that this experience "definitely helped me grow as a writer in the sense that I am more aware of how I state 
things." Ultimately this became a mastery experience and her efficacy as a writer was further developed.

As a child, Bella loved (physiological arousal) writing and then... she "had to teach it." Although she scored in the moderate range, as a teacher of writing, Bella stated that she does not feel very efficacious. She believed that writing would be "easier and more fulfilling" to teach but she finds it "much harder." I noted in my interview notes that at this point in the interview, she looked very deflated. She shared that she gets frustrated (physiological arousal) at herself "because writing came so easy" to her. She does not know why she "can't teach it so it comes easily" to her students. She believes that because writing came so "easily" to her, it has put her at a "disadvantage" in teaching writing. This indicates that Bella may indeed have the content knowledge for writing but lacks the pedagogical content knowledge to integrate her knowledge of writing into her teaching of writing. This pedagogical content knowledge is a crucial element of what teachers need to be successful in the classroom. Therefore, it is understandable that she finds "it very challenging to teach writing" when she "doesn't really know where or how to guide them [students] when they are having trouble with brainstorming or revisions or editing." It is difficult for her to relate to the "dread" (physiological arousal) her students feel when it is time for writing. Their lack of enthusiasm for writing may have further influenced her self-efficacy for teaching writing contributing to a negative self-fulfilling prophecy.

However, Bella did share a particular moment when she felt very efficacious as a teacher of writing. She had a student who came to her "barely able to read or write anything." After working with this student for a long time to just build her confidence, 
she wrote a "simple little story." Bella told her student that the story reminded her of Mo Willems and "it like ignited the spark and so she wrote all these stories and read them to the class!" This was "definitely a proud teaching writing moment." This was an affective experience for Bella in that the focus was on how her student and how she felt, not the student's progress. This is an example of what she cares about when it comes to teaching writing.

Bella feels efficacious as a writer but being a teacher of writing has interrupted who she is as a writer. Bella shared, "I just don't feel ethically like I am doing the best in giving them [students] the best I can because I just feel so tied down and constrained" (physiological arousal). Currently, the way in which she is "required" to teach writing feels "very isolated and jumbled" and she feels as though her writing lessons do not "flow" (physiological arousal). As Routman (2005) suggest, "Often we [teachers] kill off their [students] writing spirit and energy with all the "stuff" we [teachers] give them [students], all the talk of requirements, the lack of choice, the overfocus on correctness, and the pressure to do well on high-stakes tests" (p. 20). Bella sees the curriculum as being a set of skills to be taught in a linearly sequential order which is in direct conflict to how she personally views writing and teaching writing. The curriculum is not focused on the affective components of writing so it is not a surprise that she feels disheartened.

To summarize, Bella shared some positive mastery experiences, mostly negative verbal persuasions, and mostly positive physiological arousals as a writer. Except for the episode during her teacher preparation program, Bella shared many positive experiences while writing, which enhanced her efficaciousness as a writer. Like Calvin, the early positive experiences for Bella have allowed her to feel empowered as a writer. She shared 
a few positive mastery experiences, no verbal persuasions, and mostly negative physiological arousals associated with teaching writing. The episodes Bella shared as a teacher of writing appear to be in conflict with those she shared as a writer. This was

evident when she stated, "I thought that as someone who enjoyed writing and was good at it that teaching writing would be easier and more fulfilling but that is just not so." It is difficult for Bella to reconcile the ways in which she experienced writing and the conceptualization she has about teaching writing and the way in which her district requires her to teach writing. There are important implications for professional development in Bella's case. While her preservice program did not address the writing pedagogy that she needed to teach in line with her personal conceptions of writing, she seems eager, now that she's recognized her limitations, to gain new understandings how to best teach writing.

\section{A Portrait of Eliza}

Eliza is a third-grade teacher and has been teaching for three years. Although she is a novice teacher, she does have experience teaching at other grade levels. Eliza believes her preservice training to teach writing was adequate and her inservice training to teach writing has also been adequate. She shared that she had a specific course devoted to teaching writing in her teacher preparation program. Figure 13 illustrates her scores on the domain specific scales and subscales. 


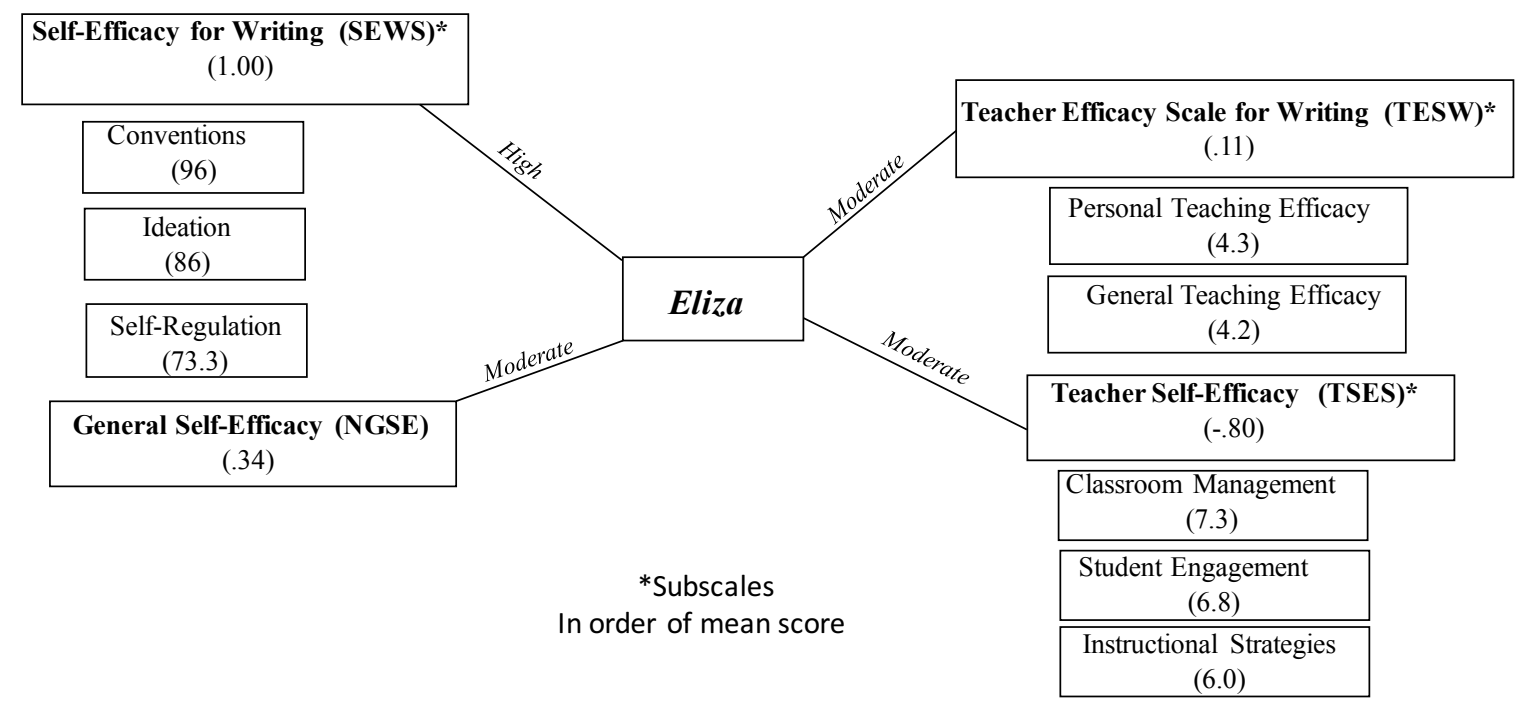

Figure 13. A Portrait of Eliza

As noted in Figure 13, Eliza scored in the high range on writing self-efficacy scale and in the moderate range on general self-efficacy, teaching self-efficacy, and teaching writing self-efficacy. Her scores on the conventions, ideation and self-regulation subscales are relatively close in range as is her personal and general teaching efficacy. She perceived herself to be most efficacious in her classroom management and least efficacious in implementing instructional strategies.

During her interview, Eliza shared stories that provided evidence of her selfefficacy as a writer and a teacher of writing as she constructed narratives of her practice and interactions with students. Figure 14 illustrates Eliza's sources of efficacy as a writer and a teacher of writing. 


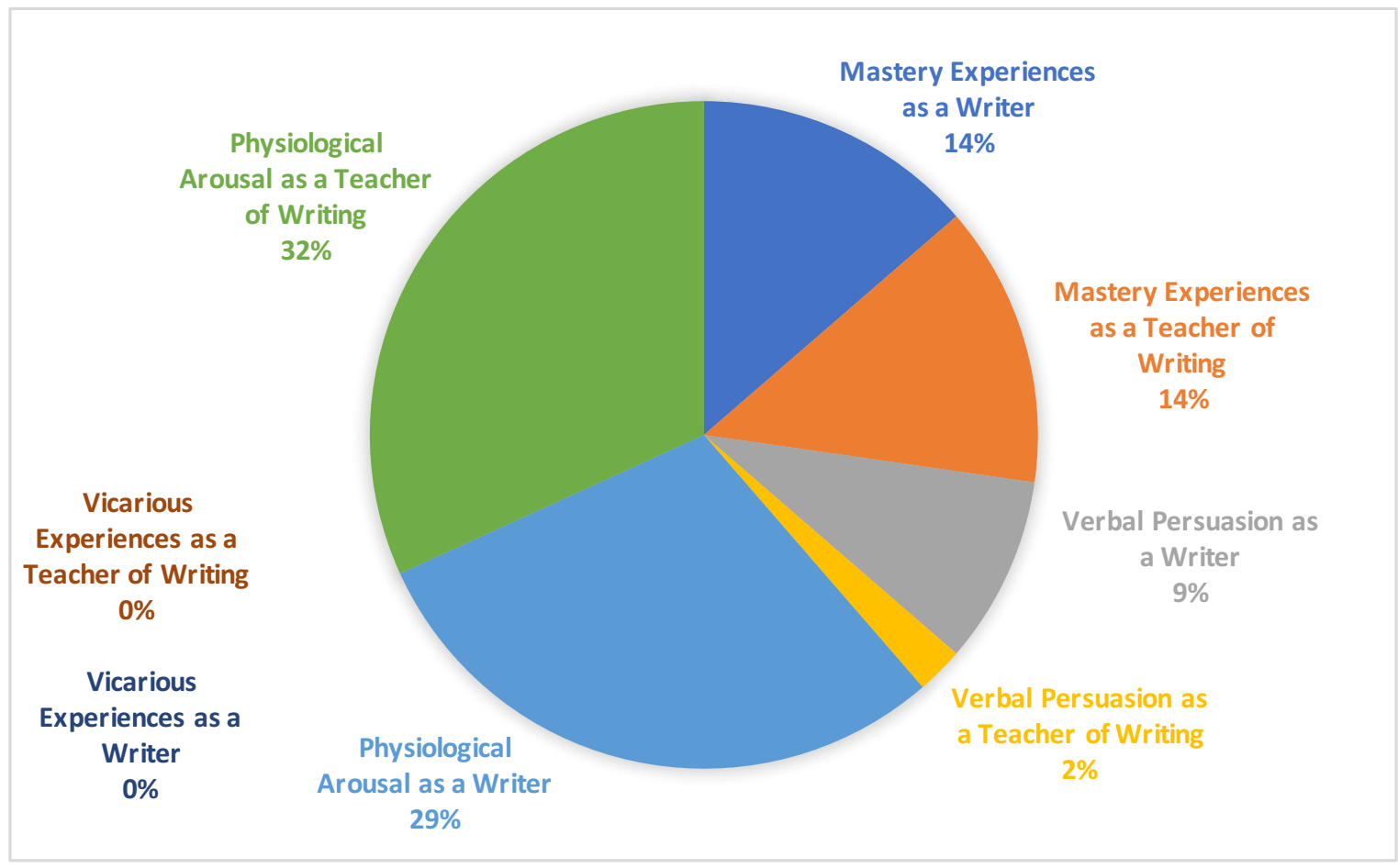

Figure 14. Eliza's Sources of Efficacy Information

As noted in Figure 14, the most influential source of efficacy for Eliza appears to be physiological reactions both as a writer and a teacher of writing. As a writer, these episodes were positive and occurred in an out-of-school setting. A physiological arousal Eliza shared was, "I felt extremely confident because I was in a safe place with other people and I was doing something incredibly enjoyable." As a teacher of writing, these episodes were almost equal between positive and negative. A physiological arousal she shared as a teacher of writing was, “I just get frustrated when I don't get to design my own curriculum" and "I am able to plug my enthusiasm into teaching writing in my classroom."

Eliza loves (physiological arousal) writing and, like Calvin and Bella, sees herself as a writer. She describes herself as an "enthusiastic amateur." Eliza writes for fun and has been writing from a very early age. She recalled several out-of-school experiences 
that impacted her as a writer. She began journaling in kindergarten when she would dictate her thoughts to her mom who would write them down. Her parents provided encouragement (verbal persuasion) in her writing and she always "felt that her words mattered." This praise from others, especially, her parents, had an impact on Eliza's selfefficacy for writing. It was in fifth grade that Eliza first considered herself to be a "really good writer." She distinctly remembers writing a descriptive piece about a dolphin. She clearly remembers her teacher saying (verbal persuasion), "Your descriptions were so gorgeous and I could see and feel the dolphin." Not only did her parent's verbal comments about her work enhance her self-efficacy as a writer, but her teacher's verbal comments did as well.

In middle school, she and a group of her Girl Scout friends passed a notebook around at camp and would take turns writing about something their characters did in the story they were composing. She shared that this experience was "just magic" and "amazing!" Eliza's efficacy for writing is affected by her interaction with this group of friends in that she can share with them without fear of them "judging" her work. This is an example of a mastery experience as well as a physiological arousal in that the language Eliza uses to describe this episode is all about her feelings and her enthusiasm. In high school, like Calvin and Bella, Eliza had some of her work submitted to the high school Literacy Magazine. This was a mastery experience and one that boosted her selfefficacy as a writer.

She believes that writing is "cathartic" and that "there is something so inviting about a blank piece of paper." Writing has been a big part of Eliza's life both in and out of school. She perceives herself to be efficacious as a writer and believes that writing has 
added to her development as a person. Writing has helped her develop a "reflective quality" and has forced her to look at herself outside of herself. These positive physiological arousals while writing have influenced Eliza's self-efficacy.

Eliza has a broad definition of writing, "Writing is putting ephemeral and abstract thoughts into a more concrete form. Writing is the act of tracking one's train of thought. Writing is the filling of a blank page with a world made from ink and words." When Eliza thinks about writing she does not think of past school experiences, but instead thinks of all her "self-directed personal writing pieces and projects." She has experienced success with writing in the past and these experiences have positively impacted her selfefficacy.

As a teacher of writing Eliza is "confident" in her ability to get her students to like writing when they get to choose their own topic. She shared that she is "less confident" in her ability to follow a specific curriculum where all students are expected to write on the same topic and produce a uniform product." She stated:

We're taking these beautiful unique lumps of humanity and we're trying to fit them into machine-like cogs and it doesn't work that way. You know we just kind of talk the talk but we don't walk the walk because we're saying all our kids are beautiful snowflakes and they're all unique and wonderful and special but we don't treat them that way but we are expected to and then we're expected not to. It's just very frustrating!

As a teacher of writing, Eliza understands that she is building her student's sense of writing efficacy when they have multiple opportunities to choose their own topics, 
however the lack of alignment between her beliefs and the curriculum causes her much "stress and anxiety" (physiological arousal). She has always loved "expressing herself in writing" and wants to "cultivate that love" in her students. This is a physiological arousal for Eliza and one that she wants to instill in her students as well.

Eliza has efficacy as a writer but as a teacher of writing she feels as though her agency has been taken away. Her love of writing (physiological arousal) has been "interrupted" by the way in which she is required to teach writing in her classroom. Currently, she is required to follow the district's curriculum and she feels "constrained" (physiological arousal), like Bella, by the way in which she must teach writing. As Routman (2005) posits, "Teaching writing is a serious problem in schools. We are overfocused on procedures, processes, genres, and testing and underfocused on thinking, communicating, inquiring, and exploring language" (p.5). As a teacher of writing, the context in which she is required to teach may be impacting her self-efficacy, but also she is a novice teacher which might also be contributing to her lack of efficacy in thinking she cannot stand up and teach writing the way she wants. Although this is a challenge for Eliza, she is still able to nurture her writing sense of efficacy because she has found a way to incorporate something she loves, writer's notebooks, into her classroom.

To summarize, Eliza shared several positive mastery experiences, several positive verbal persuasions, and mostly positive physiological arousals as a writer. Based on Eliza's experiences as a writer, it is not surprising that she sees herself as a writer. From early on she had positive experiences that empowered her and allowed her to perceive herself as an efficacious writer. She only shared some positive mastery experiences, one verbal positive persuasion, and many physiological arousals associated with teaching 
writing. Like Bella, it is difficult for Eliza to reconcile the ways in which she experienced writing and the conceptualization she has about teaching writing and the way in which her district requires her to teach writing. Unlike Bella, Eliza seems to be analyzing her current teaching context and the specific ways in which it is limiting her ability to teach writing as she would like to. She understands the conflict between the required curriculum and her pedagogical instincts, and she has begun to find ways of to infuse her approach to writing in small parts of the curriculum. Perhaps it is her strong efficacy as a writer, paired with her more developed preservice background in literacy pedagogy, that has given her the ability to move beyond the constraints of her teaching context.

\section{Summary}

In returning to the proposed Integrated Model of Teacher Self-Efficacy in the Domain of Writing, there were identified sources of efficacy as a writer and teacher of writing. The participants in this study described their mastery experiences, verbal persuasions, and physiological arousals as writers and teachers of writing. The mastery experiences are based on an individual's perceptions of their success and failures (Bandura, 1977). Verbal persuasions occur when an individual is socially persuaded, either positively or negatively, about the ability she possesses to accomplish a task. The physiological arousals are the somatic indicators (Bandura, 1997) such as negative and positive moods. These sources are cognitively processed by each participant which influences the components that a teacher considers when evaluating self-efficacy, analysis of the teaching task and the assessment of the personal teaching competence. Through cognitive processing, teachers interpret the information they receive to frame 
and reframe the task of teaching writing and the assessment of personal teaching competence in teaching writing. The level of efficacy determines the teaching performance, which becomes a new source of efficacy information. Thus, greater efficacy leads to greater effort and persistence, which leads to better performance, which leads to greater efficacy and the cycle continues (Tschannen-Moran et al., 1998). As the model comes full circle, "a teaching performance that was accomplished with a level of effort and persistence influenced by the performer's sense of efficacy, when completed, becomes the past and a source of future efficacy beliefs" (Tschannen-Moran et al., 1998, p. 234).

If one feels more efficacious they will seek more opportunities that will feed the cycle. They will continue to teach more writing which gives them more potential sources of efficacy. Conversely, someone who feels less efficacious potentially teaches writing less and generates fewer and fewer sources of efficacy to feed the cycle; therefore, causing self-efficacy to become weaker and weaker. In this study, self-efficacy manifested itself differently in different individuals.

Important to note, there was one source of efficacy that was not mentioned by any of the participants. Vicarious experiences occur when individuals observe other people model or perform a task. Bandura (1997) suggests, "these different forms of efficacy influences rarely operate separately and independently" (p. 87). As writers and teachers of writing, the sources of self-efficacy may not be equal in shaping an individual's selfefficacy. This is because there may also be contributing contextual factors (i.e., school climate, curriculum). The manner in which the participant interpreted the sources of efficacy impacted her self-efficacy as a writer and teacher of writing. 
In this study five elementary classroom teachers responded to various domain specific self-efficacy scales and participated in a narrative interview. By gathering data that captured each element of Tschannen-Moran et al.'s (1998) revised model as it relates to writing, teaching, and teaching writing, I collected and analyzed a corpus of data based on which I developed the following claims:(a) personal experiences as a writer and teacher of writing impact teachers' self-efficacy for writing and teaching writing; (b) the influences of writing as a highly affective experience; (c) within individual teachers there is variability across and within the various domain specific self-efficacy scales; and (d) the number of years of teaching experience does not necessarily correlate to higher levels of teaching writing efficacy. 


\section{Chapter 5: Discussion, Implications, and Conclusion}

\section{Overview}

Literacy research suggests unequivocally that writing is a difficult and complex cognitive task. At the same time, writing has been deemed the neglected " $R$ " and the effects of being "neglected" are quite clear. Acknowledging the many factors that may contribute to this, teachers play a critical role in promoting change just as teachers play a central role in the academic success of students (Darling-Hammond \& Bransford, 2005). A teacher's sense of efficacy is a significant factor in how teachers' view themselves as writers and teachers of writing (Bandura, 1997). While there are a range of factors that might relate to teachers' resistance to teach writing, this study examined the ways in which the domain specific self-efficacies manifest themselves in the teaching of writing because self-efficacy has been shown to be central in teacher's practice. "In these days of hard-nosed accountability, teachers' sense of efficacy is an idea that neither researchers nor practitioners can afford to ignore” (Tschannen-Moran \& Hoy, 2001, p. 803).

\section{Summary of Findings}

For this study five elementary classroom teachers responded to various domain specific self-efficacy scales and participated in a narrative interview. By gathering data that captured each element of Tschannen-Moran et al.'s (1998) revised model as it relates to writing, teaching, and teaching writing, I collected and analyzed a corpus of data based on which I developed the following claims:(a) personal experiences as a writer and teacher of writing impact teachers' self-efficacy for writing and teaching writing; (b) the influences of writing as a highly affective experience; (c) within individual teachers there is variability across and within the various domain specific self-efficacy scales; and (d) 
the number of years of teaching experience does not necessarily correlate to higher levels of teaching writing efficacy.

\section{Discussion of the Findings}

In this section I will discuss the findings of the study. For the first two findings, I will discuss them in terms of the participants as writers and the participants as teachers of writing. For the next two findings, I will discuss them combining the experiences of the participants as writers and teacher of writing.

\section{Personal Writing Experiences}

Experiences as a writer. On the Self-Efficacy for Writing Scale, Eliza and Calvin scored in the high range and Bella scored in the higher end of the moderate range. The nature of one's experiences as a writer and teacher of writing influences self-efficacy for writing and teaching writing. Significant in their descriptions of their writing experiences was how participants described their position relative to writing. Participants fell neatly into two groups: those with positive recollections related to self-efficacy and writing and those with negative recollections. The first group all spoke about themselves as writers. The early writing experiences they described were filled with language that empowered them. When speaking of their mastery experiences they shared statements like "Writing has always been a creative outlet for me" (Bella) or, "I won writing competitions" (Calvin). When speaking of the verbal feedback they received they were told that their words were important and their words mattered. Their parents, teachers, or peers validated them as writers. When speaking of their physiological arousals they shared statements like, "I was just thinking about the joy of writing!" (Eliza) or, "I have always enjoyed writing even as a little kid (Bella)." It appears their mastery experiences, 
verbal persuasion, and physiological arousals have contributed to their identity as a writer.

In contrast, the second group spoke about their early writing experiences very differently, not about personal identity or empowerment, but about learning specific conventions. As Hillocks (2005) argues, "For many years the teaching of writing has focused almost exclusively and to the point of obsession on teaching the forms of writing - the parts of paragraphs, the parts of essays, the structure of sentences, the elements of style, and so forth" (p. 238). Indeed, when Patsy and Daisy spoke of their early experiences as writers, they shared statements like, "I don't remember doing much writing in school...I remember mostly grammar, mechanics, spelling... and oh yeah diagramming sentences" (Daisy) or, "Writing consisted of grammar worksheets, copying from books, handwriting, and spelling" (Patsy). Most of their recollections were negative and unlike the first group, they do not 'see' themselves as writers. This group stated their distaste for writing by sharing that writing was "a laborious activity" (Patsy) or, "not an enjoyable experience (Daisy)." Hillocks (2005) also contends, "knowledge of form does not translate into the strategies and skills necessary to wrest from subject matter the ideas that make up a piece of writing” (p. 238). Perhaps because Patsy's and Daisy's experiences were not deeply developed enough or were too narrow in their scope to translate to more sophisticated writing instruction, they never took on the identify of writers or teachers of writing. It appears their writing experiences have not contributed to their identity as writers.

Experiences as a teacher of writing. Perhaps because the first group identified themselves as writers and writing was an empowering experience, they spoke about how 
they wanted their students to experience writing in a positive and empowering way. They shared statements like, "I was always so excited to write and I want my students to feel and experience that as well..." (Bella) or, "I am confident in my ability to get my kids to like writing when they get to do things like choose their own topics" (Eliza). However, while positive personal experiences seemed to translate to higher self-efficacy for writing for these participants, that personal empowerment was limited in its connection to their self-efficacy for teaching writing. For two teachers in this group, they described, with great frustration, how their autonomy had been taken away because of the way in which they are required to teach the curriculum. They shared statements like, "I feel constrained when I am teaching [writing]" (Eliza) or, "The curriculum feels very isolated and jumbled and things just don't seem to flow" (Bella). Both Bella and Eliza found it difficult to reconcile the ways in which they experienced writing and the conceptualization they have about teaching writing and the way in which their respective districts require them to teach writing. Zancanella (1991) had similar findings in his study of teachers' personal approaches to literature and their teaching of literature. He argued, "To the extent that these teachers' personal approaches to literature represent a part of what they know about literature, the task of transforming that content knowledge into pedagogical content knowledge is obstructed by a school version of literature which is at odds with how and why they themselves read" (Zancanella, 1991, p. 27). A parallel claim can be made about these participants' approaches to writing and how they approach teaching writing given their schools contexts.

Because the second group did not identify themselves as writers and writing was not an empowering experience, they seem to perpetuate the cycle of what Hillocks (2005) 
refers to as the 'forms of writing.' They shared statements like, "When I teach writing I spend a lot of time on paragraphs...main idea, details to support the main idea, and then conclusions" (Patsy) or, "I feel like I can teach the basics, like grammar, mechanics, and conventions, to my students" (Daisy). From the episodes, they shared, both Daisy and Patsy, teach writing in the ways in which they were taught, a legacy of their apprenticeship of observation. As Smagorinsky and Barnes (2014) suggest, "In this conception students are exposed largely to teacher-and-text-centered pedagogies, a cycle that repeats itself across generations of teachers" (p. 29).

\section{The Influences of Writing as a Highly Affective Experience}

Experiences as a writer. Bandura (1997) maintains that the cognitive processing of physiological states is particularly important and how we perceive and interpret somatic indicators may be more indicative to the consequential behavior than the actual physiological state itself. Factors such as mood and levels of stress can influence physiological and affective states (Usher \& Pajares, 2008).

The first group of teachers recalled more positive physiological arousals than negative. It is not surprising, given that this group views themselves as writers and recalled more positive episodes with writing than negative. They shared statements such as, "I was doing something incredibly enjoyable" (Eliza) or, "I enjoy it [writing]. It is not something that scares me" (Calvin). It is evident, from these comments, that writing is something that is perceived as a positive experience. As McLeod (1987) posits, “...writing is an emotional as well as cognitive activity - we feel as well as think when we write" (p. 426). 
In contrast, the second group of teachers recollected more negative physiological arousals than positive. This is understandable because they do not view themselves as writers and they recollected more negative episodes as writers than positive episodes. They shared statements such as, "I don't enjoy writing and see it as an overwhelming task" (Daisy) or, "I had a lot of anxiety just figuring out what I was going to write" (Patsy). The negative experiences they had as writers have implications for the way in which they teach writing in their classrooms.

Experiences as a teacher of writing. Again, when speaking of physiological states, I am referring to the participants and their affective reactions (emotions and feelings) as teachers of writing. Tschannen-Moran et al. (1998) state, “The level of emotional and physiological arousal a person experiences in a teaching situation adds to self-perceptions of teaching competence" (p. 229). These can be either positive or negative arousals.

The first group of teachers recalled slightly more negative physiological arousals as teachers of writing than positive. They shared statements such as, "It's hard to teach writing to kids especially if they don't like it" (Calvin) or, "I was very frustrated because I could not figure out for the life of me how else to explain it" (Bella). Much of their frustration in teaching writing is that writing came easily to them and, at times, they had a difficult time showing empathy for their students. As teachers, they shared that it was hard to "break down the writing process" for their students because this is something they never experienced as a student.

In contrast the second group of teachers recalled more positive physiological arousals as teachers of writing than negative. They shared statements such as, "I love this 
lesson. I use it every year because my kids enjoy it" (Daisy) or, "I felt pretty confident because I have used this same lesson for many years" (Patsy). The lesson that both Daisy and Patsy spoke of were very structured teacher directed lessons with little or no input from their students (i.e., graphic organizer, format for published piece). The need for control over this assignment might be attributed to their low self-efficacy as a teacher of writing. Neither teacher feels as though she can relinquish control because she does not believe she can be responsive to her students.

\section{Lack of Consistency Across and Within the Various Domain Specific Efficacy}

\section{Measures}

The complex constellation of factors manifested differently for each participant. Perhaps this reveals something about how complex teaching is. Rare is it that anyone feels efficacious in all elements of their teaching especially when talking about elementary teachers who have so many different content responsibilities, developmental responsibilities, and social responsibilities. The elementary teacher is a special teacher because the elementary teacher is expected to do all of it and do all of it well.

Research has shown that self-efficacy is context and domain specific. However, prior to this study, I thought these various domains may be somewhat related. For example, teaching and teaching writing do not seem like completely distinct domains. I thought I would see some consistency, particularly in the high levels. But, that was not the case as I found that with efficacy, the whole is not a sum of its parts. For example, Bella scored in the high range for teaching efficacy but in the moderate range for teaching writing efficacy. Perhaps this is because she feels constrained by the requirements of the district when teaching writing and not other content areas. As 
previously stated, Bella sees the curriculum as being a set of skills to be taught in a linearly sequential order which is in direct conflict to how she personally views writing and teaching writing. The curriculum is not focused on the affective components of writing. In addition, Calvin scored in the moderate range for teaching efficacy but in the high range for teaching writing efficacy. This may be because he perceives himself to be a highly efficacious writer and has an identity as a writer.

\section{Number of Years of Teaching Experience Does Not Result in Higher Efficacy for Teaching Writing}

Literature suggests that more experienced teachers self-report a higher sense of teacher efficacy that less experienced teachers (i.e., Putman, 2012; Tschannen-Moran \& Woolfolk Hoy, 2007), however, the findings of this study did not demonstrate this relationship. Although, Patsy has the most years of teaching experience, the only measure she had in the high range was general self-efficacy, not writing, teaching, or teaching writing. In contrast, Eliza has the least teaching experience and she was in the moderate range for general efficacy, teaching efficacy, teaching writing efficacy, and in the high range for self-efficacy for writing.

It is important to point out that all experiences are not equal and some are more influential than others in the same way that the sources of efficacy are not all equal in their impact on efficacy. Efficacy in one area does not mean efficacy in another. It is the nature of the experiences, not the experience in and of itself. The experiences that the participants recalled as writers and teachers of writing were the ones that had meaning. 


\section{Implications of the Findings}

The results of this study have important implications for teacher preparation programs, teacher professional development, and future research. Both preservice and inservice programs have a critical responsibility in developing not only a teachers' conceptualization of writing but also their self-efficacy as a writer and teacher of writing.

\section{Implications for Teacher Preparation Programs}

Despite the importance of writing, many teachers are not well prepared to teach writing. In 2011, the National Assessment of Educational Progress (NAEP) reported that $27 \%$ of assessed students performed at or above the proficient level in writing (National Center for Education Statistics, 2012) continuing a trend of severely low performance from previous years. Prior to $2011,25-30 \%$ of students scored proficient on the annual NAEP writing assessment (National Center for Education Statistics, 2012). Despite these claims, very few states require specific coursework in the teaching of writing and many teacher preparation programs allocate their literacy components to reading with very little writing pedagogy embedded (Norman, 2005).

Ashton (1984) argued,

In order for teacher efficacy to be more than simply an ideology that teachers can articulate, a teacher education program designed to foster teacher efficacy must include training experiences enabling preservice students to develop the human relations skills essential for establishing and maintain trusting relations with and encouraging autonomy in students (p.30).

It is important to provide our preservice teachers with the knowledge they need to feel 
efficacious because they carry these views into their classrooms. For example, both Bella and Eliza went through the same program several years apart. Eliza, however, took an English Language Arts methods course whereas Bella did not because this specific course was not a requirement. Eliza purposefully selected courses to extend her knowledge of teaching writing, ambitiously choosing courses well beyond the minimum requirements. Again, efficacy and knowledge are two different ingredients, but they are not unrelated. For this reason, courses should be designed for teacher preparation programs that include not only positive experiences with writing but a self-efficacy component as well. Specifically, courses should include opportunities for mastery experiences, vicarious experiences, verbal persuasions, and physiological arousals as a writer and teacher of writing. Vicarious experiences were surprisingly absent from all the participant's recollections. This suggests that our preservice teachers need placements where they can actually see an experienced teacher demonstrating these writing processes that are beneficial for our students. Perhaps the course could have a dual focus on living as a writer and the pedagogy of teaching writing. Bomer (2010) suggests, "Teaching writing without doing it ourselves is like trying to teach a four-year-old how to tie shoes when we have only worn flip-flops our entire life" (p.77). The findings of this study seem to indicate those who had positive early experiences as a writer identify as a writer and those who did not have positive early experiences did not identify as a writer. Teacher educators could potentially change the way in which preservice teachers view themselves as writers and teachers of writing. Feiman-Nemser (2001) argues, "Unless teacher educators engage prospective teachers in a critical examination of their entering beliefs in light of compelling alternatives and help them to develop powerful images of good 
teaching and strong professional commitments, those entering beliefs will continue to shape their ideas and practices" (p. 1017). If we are to make a change in the ways in which we are teaching writing, we must first examine our beliefs about writing and who we are as writers.

If knowledge is boosted, hopefully, self-efficacy is boosted as well. WoolfolkHoy (2000) argues, "efficacy may be most malleable early in learning; thus, the first years of teaching could be critical to the long-term development of teacher efficacy" ( $p$. 2). Self-efficacy is a construct that merits our attention.

\section{Implications for Professional Development}

To effect affect, we need ongoing, longitudinal, and authentic professional development as suggested by the findings from this study. While there is a plethora of professional development opportunities for writing that offer a quick fix in a day or two, Calkins and Ehrenworth (2016) maintain that professional development should be “ongoing, comprehensive, intense, collaborative, collegial, and practical" (p. 13). Traditionally, professional development has treated teachers as passive learners where there has been no ongoing support from a mentor or coach and space is not provided for teachers to reflect on their practices. To assist our students, learn the more complex skills needed for the $21^{\text {st }}$ century, education systems must offer more effective learning than has traditionally been available (Darling-Hammond \& Richardson, 2009). Teachers need the opportunity to be active learners. Teacher need to have ongoing support from a mentor or coach and most importantly, teachers need the space to reflect on and study their own practices. Access to high-quality professional development will provide these things as well as influences the many decisions a teacher makes about curriculum, students, 
instruction.

While professional development for teachers can take a variety of forms, one model that is authentic and longitudinal is the National Writing Project. The National Writing Project (NWP) is a professional development network that focuses on improving writing and learning in our schools, putting teacher expertise and networks at "the heart" of its professional development model (National Writing Project \& Nagin, 2006, p. 63). One of the core tenants of the National Writing Project is "teachers of writing must be writers." "We cannot build a nation of educated people who can communicate effectively without teachers and administrators who value, understand, and practice writing themselves" (National Writing Project \& Nagin, 2006, p. 60). This is yet another reason why writing can no longer be the neglected "R." It takes a long-term commitment of all if we are to make a difference both as writers and teachers of writing.

Research on effective professional development emphasizes the importance of collaborative and collegial learning environments in which teachers support one another in improving practice (Darling-Hammond \& Richardson, 2009). This is so important in the teaching of writing because if there is a teacher who is exemplifying how we want writing to be taught, other teachers can observe (vicarious experience) and learn from that teacher. Not only can teachers learn from one another but the ongoing support and encouragement of a colleague is invaluable.

The effectiveness of professional development relies on high teacher self-efficacy. However, this is a 'Catch 22' - to increase self-efficacy we need professional development; for professional development to be effective we need high self-efficacy. According to Tschannen-Moran and McMaster (2009), "One of the most interesting and 
important reasons for scholars and school leaders to pay attention to teachers' selfefficacy is the role it plays in teachers' implementation of new teaching strategies presented through professional development" (p. 231). This is so important because teachers can be offered many professional development opportunities, but if they do not feel efficacious enough to implement their new learning in the classroom, what was the purpose?

The benefit of ongoing, professional development allows us "to begin where the teachers are, acknowledging that the writing histories of teachers are a vital consideration when working with teachers" (Street \& Stang, 2009, p. 76). It is important to remember that it is not just about the teachers, it is about our students as well.

\section{Implications for Students and Equity}

Currently our practices in the classroom are creating inequities for our students. As the portraits of Patsy and Daisy suggest, many teachers embrace the autonomous model (Street, 1995) of writing "rooted in teachers' past experiences" and "historical conceptions of writing” (Cremin \& Oliver, 2016, p. 23). Our classrooms are more diverse than ever before. As such, teaching in a way that suggests only one narrow path towards writing may not successfully build from the range of prior knowledge that students possess.

Embracing the autonomous model is further exacerbated by the sociopolitical time in which we live. The ways in which we are assessing and teaching writing have been standardized. Federal legislation focusing on public education requires more assessments, more explicit standards for learning, and often results in more prescriptive 
instruction. The attention given to standardized testing has prompted teachers to instruct students to write formulaic essays (e.g., five-paragraph essay) that focus on producing a uniform product limited in scope. The writer has no voice in choosing the topic and likely little knowledge or interest in that particular topic. The writer has not been afforded the luxury of time to develop and cognitively process her thoughts. We have now moved on to computerized test taking in which writing has been turned into writing by formula which is scored based on the number of words in a sentence, the number of words on a page, and the number of transition words used. This is in direct conflict to what we know about writers and writing, that writing takes different forms for different people. This is not only an issue of equity for our students but may be contributing to why teachers have low self-efficacy as writers and low self-efficacy as teachers of writing.

Likewise, the writing process has been standardized for all students and treated like a linear process in which specific steps are followed in a specific order. For example, in the elementary classroom we have turned writing into a process of brainstorming on Monday, drafting on Tuesday, revising on Wednesday, editing on Thursday, and publishing on Friday. However, teachers could embrace the ideological model (Street, 1995) of writing that "recognizes the diversity and complexity of literacy practices; they are every day, situated and multiple (Cremin \& Oliver, 2016, p. 23). The ideological model of literacy creates a space in which the writer's prior experiences of the world, social identification, attitudes, and the surrounding culture and society are contributors to the outcome of the negotiations of meaning (Street, 1984). Thus, by offering students multiple pathways towards conceptualizing writing, we not only authentically present writing to students, but we allow for more opportunities for students to connect writing to 
their cultural ways of knowing, and thus more effectively develop students' writing efficacy. As early experiences shape future literacy orientations (Bernstein, 2014), creating more opportunities for elementary students to meaningfully engage with writing may have lasting effects. In contrast, by limiting spaces - quite literally - for students to build from their prior knowledge and experience, we limit opportunities for them to develop an identity as a writer, because writing is not personal in such spaces.

Thus, writing needs to be taught in a variety of culturally responsive ways to meet the needs of the range of students in our classrooms. There is not just one way to teach writing. It is an iterative process - a series of recursive steps. For example, we need to disrupt the common practice of thinking that all students need to brainstorm before writing and that writing is a linear process where all students need to be doing the same thing on the same day. We need to reconceptualize how we assess writing, and, perhaps most importantly, help teachers develop deep pedagogical content knowledge so they can be effective and feel efficacious.

Teaching writing well means knowing our individual students and building their writing knowledge in ways that matter to them. In so doing so, instruction in the classroom will be empowering for all, not just a certain group of students (LadsonBillings, 2009). As the portraits of Bella, Calvin, and Eliza suggest, when we position our students to be successful writers, we provide them opportunities to gain a sense of selfefficacy about their writing that can blossom in years to come.

\section{Recommendations for Future Research}

This study's findings have implications that may prove valuable for future research. The literature related to teacher self-efficacy in the domain of writing is 
extremely limited. There is a need for more research examining how teachers develop their self-efficacy for writing and teaching writing. In addition, there is also a need to explore the ways in which the sources of efficacy influence them as writers and teachers of writing.

Another recommendation for future research is to develop and research professional development and teacher education designs that emphasize efficacy. What might this look like? In addition, it would also be interesting to examine existing professional development (e.g., NWP) specifically looking at efficacy.

\section{Concluding Thoughts}

I have always thought of myself as a life-long learner and learning is something that I have always had a passion for. The journey I have been on the past six years has been filled with many highs and lows. Sitting down and writing this dissertation has been a daunting and challenging task. As someone who has not had many positive writing experiences, this was a new writing challenge. There were times when the words flowed and times when writing felt strenuous and frustrating. There were times of elation and excitement. There were times when I knew I could do it and times when I thought I could not. I must admit it was not easy for me to have my work read because the many insecurities I experienced as a student came creeping up and I would momentarily question my abilities as a writer. The sweaty palms, racing heart, and anxious moments occurred often. The fear of the red pen surfaced. However, I listened intently and accepted the feedback because it was what I needed to become a better writer.

Throughout this experience I noticed the various sources of efficacy. There were mastery experiences, vicarious experiences, verbal feedback, and physiological arousals. 
Like the results of this study, the physiological arousals far outweighed any of the other sources of efficacy. But through it all I persevered and am ecstatic to have crafted a dissertation of which I am very proud. 


\section{References}

Ashton, P. (1984). Teacher efficacy: A motivational paradigm for effective teacher education. Journal of Teacher Education, 35(5), 28-32.

Ashton, P. T., \& Webb, R. B. (1986). Making a difference: Teachers'sense of efficacy and student achievement. New York: Longman.

Atwell, N. (1987). In the middle: Writing, reading, and learning with adolescents. Upper Montclair, N.J: Boynton/cook.

Bandura, A. (1977). Self-efficacy: Toward a unifying theory of behavioral change. Psychological Review, 84(2), 191-215.

Bandura, A. (1986a). Social foundations of thought and action. Upper Saddle River, NJ: Prentice Hall.

Bandura, A. (1986b). The explanatory and predictive scope of self-efficacy theory. Journal of Social and Clinical Psychology, 4(3), 359-373)

Bandura, A. (1993). Perceived self-efficacy in cognitive development and functioning. Educational Psychologist, 28, 117-148.

Bandura, A. (1994). Self-efficacy. In V.S. Ramachadran (Ed.). Encyclopedia of Human Behavior (pp. 71-81). New York: Academic Press.

Bandura, A. (1995). Self-efficacy in changing societies. Cambridge: Cambridge University Press.

Bandura, A. (1997). Self-efficacy: The exercise of control. New York, NY: W.H. Freeman and Company.

Bernstein, M. (2014). Three planes of practice: Examining intersections of reading identity and pedagogy. English Teaching: Practice and Critique, 13(3), 110-129. 
Bomer, K. (2010). Hidden gems: Naming and teaching from the brilliance in every student's writing. Portsmouth, NH: Heinemann.

Brooks, G. W. (2007). Teachers as readers and writers and as teachers of reading and writing. The Journal of Educational Research, 100(3), pp. 177-191.

Bruner, J. (1991). The narrative construction of reality. Critical Inquiry, 18(1), 1-21.

Bruning, R., Dempsey, M., Kauffman, D. F., McKim, C., \& Zumbrunn, S. (2013). Examining dimensions of self-efficacy for writing. Journal of Educational Psychology, 105(1), 25-38.

Bruning, R. H., \& Kauffman, D. F. (2016). Self-efficacy beliefs and motivation in writing development. In C. A. MacArthur, S. Graham, \& J. Fitzgerald (Eds.), Handbook of writing Research (2 ${ }^{\text {nd }}$ ed., pp. 160-173). New York, NY: The Guilford Press.

Calkins, L. (1986). The art of teaching writing. Portsmouth, NH: Heinemann.

Calkins, L., \& Ehrenworth, M. (2016). Growing extraordinary writers: Leadership decisions to raise the level of writing across a school and a district. The Reading Teacher, 70(1), 7-18.

Chapman, M. (2006). Preschool through elementary writing. In P. Smagorinsky (Ed.), Research on composition: Multiple perspectives on two decades of change (pp. 15-47). New York, NY: Teachers College Press.

Chen, G., Gully, S. M., Eden, D. (2001). Validation of a new general self-efficacy scale. Organizational Research Methods, 4(1), 62-83.

Claypool, S. H. (1980). Teacher writing apprehension: Does it affect writing assignments across the curriculum? (ERIC Document Reproduction Service No. ED216 387). 
Coladarci, T. (1992). Teachers' sense of efficacy and commitment to teaching. The Journal of Experimental Education, 60(4), 323-337.

Cremin, T., \& Myhill, D. (2012). Writing voices: Creating communities of writers. New York, NY: Routledge.

Cremin, T., \& Oliver, L. (2016). Teachers as writers: A systematic review. Research Paper in Education, 32(3), 269-295, DOI: 10.1080/02671522.2016.1187664.

Creswell, J. W., \& Plano Clark, V. L. (2007). Designing and conducting mixed methods research. Thousand Oaks, CA: Sage.

Cutler, L., \& Graham, S. (2008). Primary grade writing instruction: A national survey. Journal of Educational Psychology, 100(4), 907-919.

Darling-Hammond, L., \& Bransford, J. (2005). Preparing teachers for a changing world: What teachers should learn and be able to do. San Francisco, CA: JosseyBass.

Darling-Hammond, L., \& Richardson, N. (2009). Teacher learning: What matters? Educational Leadership, 66(5), 46-53.

Dix, S., \& Cawkwell, G. (2011). The influence of peer group response: Building a teacher and student expertise in the writing classroom. English Teaching: Practice and Critique, 10(4), 41-57.

Fletcher, R., \& Portalupi, J (2001). Writing workshop: The essential guide. Portsmouth, NH: Heinemann.

Feiman-Nemser, S. (2001). From preparation to practice: Designing a continuum to strengthen and sustain teaching. Teachers College Record, 103(6), 1013-1055. 
Frank, C. R. (2003). Mapping our stories: Teachers' reflections on themselves as writers. Language Arts, 80(3), 185-195.

Gibson, S., \& Dembo, M. H. (1984). Teacher efficacy: A construct validation. Journal of Educational Psychology, 76, 569-582.

Gilbert, J., \& Graham, S. (2010). Teaching writing to elementary students in grades 4-6: A national survey. The Elementary School Journal, 110(4), 494-517.

Goddard, R. D., Hoy, W. K., \& Woolfolk Hoy, A. (2000). Collective teacher efficacy: Its meaning, measure, and impact on student achievement. American Educational Research Journal, 37, 479-508.

Graham, S., \& Harris K. R. (2009). Almost 30 years of writing research: Making sense of it all with The Wrath of Khan. Learning Disabilities Research \& Practice, $24(2), 58-68$.

Graham, S., \& Harris, K. R. (2013). Common core state standards, writing and students with LD: Recommendations. Learning Disabilities Research \& Practice, 28(1), 28-37.

Graham, S., \& Harris, K.R. (2015). Common core state standards and writing. The Elementary School Journal, 115(4), 457-463.

Graham, S., Harris, K.R., Fink, B., \& MacArthur, C.A. (2001). Teacher efficacy in writing: A construct validation with primary grade teachers. Scientific Studies of Reading, 5(2), 177-202.

Graham, S., \& Perin, D. (2007). Writing next: Effective strategies to improve writing of adolescents in middle and high school: A report to Carnegie Corporation of New York. Washington, DC: Alliance for Excellent Education. 
Graham, S., \& Sandmel, K. (2011). The process writing approach: A meta-analysis. The Journal of Educational Research, 104(6), 396-407.

Graves. D. H. (1983). Writing: Teachers \& children at work. Portsmouth, NH: Heinemann.

Graves. D. H. (1990). Discover your own literacy. Portsmouth, NH: Heinemann.

Graves, D. H. (2002). Testing is not teaching: What should count in education. Portsmouth, NH: Heinemann.

Guskey, T. R. (1981). Measurement of responsibility teachers assume for academic successes and failures in the classroom. Journal of Teacher Education, 32, 44-51.

Guskey, T. R., \& Passaro, P. D. (1994). Teacher efficacy: A study of construct dimensions. American Educational Research Journal, 31(3), 627-643.

Henson, R.K. (2002). From adolescent angst to adulthood: Substantive implications and measurement dilemmas in the development of teacher efficacy research. Educational Psychologist, 37(3), 137-150.

Hillocks, Jr., G. (2005). The focus on form vs. content in teaching writing. Research in the Teaching of English, 40(2), 238-248.

Hoy, W. K., \& Woolfolk, A. E. (1990). Socialization of student teachers. American Educational Research Journal, 27(2), 279-300.

Hsieh, H.F., \& Shannon, S. E. (2005). Three approaches to qualitative content analysis. Qualitative Health Research, 15, 1277-1288.

Kellogg, R. T. (2008). Training writing skills: A cognitive development perspective. Journal of Writing Research, 1, 1-26.

Kim, J., \& Lorsbach, A. W. (2005). Writing self-efficacy in young children: Issues for 
the early grades environment. Learning Environments Research, 8, 157-175.

Klassen, R. M. (2002). Writing in early adolescence: A review of the role of selfefficacy beliefs. Educational Psychology Review, 14, 173-203.

Klassen, R. M., Tze, V. M., Betts, S. M., \& Gordon, K. A. (2011). Teacher efficacy research 1998-2009: Signs of progress or unfulfilled promise? Educational Psychology Review, 23, 21-43.

Kvale, S., \& Brinkmann, S. (2009). Interviews: Learning the craft of qualitative research interviewing. Los Angeles, CA: Sage.

Ladson-Billings, G. (2009). The dream-keepers: Successful teachers of African American children. San Francisco, CA: Jossey-Bass.

Landon-Hays, M. M. (2012). I would teach if I knew how: Inquiry, modeling, shared writing, collaborative writing, and independent writing (IMSCI), a model for increasing secondary teacher self-efficacy for integrating writing in the content areas. (Doctoral dissertation). Retrieved from ProQuest Dissertations and Theses. (3546305).

Lavelle, E. (2006). Teachers' self-efficacy for writing. Journal of Research in Educational Psychology, 4(8), 73-84.

Linnenbrink, E. A., \& Pintrich, P. R. (2003). The role of self-efficacy beliefs in student engagement and learning in the classroom. Reading and Writing Quarterly, 19, $129-137$.

Locke,T., Whitehead, D., \& Dix, S. (2013). The impact of 'writing project' professional development on teachers' self-efficacy as writers and teachers of writing. English in Australia, 48(2), 55-69. 
Lortie, D. C. (1975). Schoolteacher: A sociological study. Chicago, IL: The University Press.

McCarthy, P., Meier, S., \& Rinderer, R. (1985). Self-efficacy and writing. College Composition and Communication, 36, 465-471.

McLeod, S. (1987). Some thoughts about feelings: The affective domain and the writing process. College Composition and Communication, 38(4), 426-435.

Morgan, D. N. (2010). Preservice teachers as writers. Literacy Research and Instruction, 49(4), 352-365.

National Center for Education Statistics. (2012). The Nation's Report Card: Writing 2011(NCES 2012-470). Institute of Education Sciences, U.S. Department of Education, Washington, D.C.

National Commission on Writing in America's Schools, and Colleges. (2003). The neglected " $r$ ": The need for a writing revolution. Retrieved from http://www.collegeboard.com/prod_downloads/writingcom/neglectedr.pdf

National Writing Project \& Nagin, C. (2006). Because writing matters: Improving Student writing in our schools. San Francisco, CA: Jossey-Bass.

Pajares, F. (1996). Self-efficacy beliefs in academic settings. Review of Educational Research, 66(4), 543-578.

Pajares, F. (2003). Self-efficacy beliefs, motivation, and achievement in writing: A review of the literature. Reading and Writing Quarterly, 19, 139-158.

Pajares, F. (2007). Empirical properties of a scale to assess writing self-efficacy in school contexts. Measurement and Evaluation in Counseling and Development, 39, 239-249. 
Pajares, M. F., \& Johnson, M.J. (1993). Confidence and competence in writing: The role of self-efficacy, outcome expectancy, and apprehension. Paper presented at the annual meeting of the American Educational Research Association, Atlanta, GA.

Pajares, F., \& Johnson, M. J. (1996). Self-efficacy beliefs in the writing of high school students: A path analysis. Psychology in the Schools, 33, 163-175.

Pajares, F., \& Johnson, M. J. (1994). Confidence and competence in writing: The role of writing self-efficacy, outcome expectancy, and apprehension. Research in the teaching of English, 28, 313-331.

Pajares, F., \& Miller, M. D. (1994). The role of self-efficacy and self-concept beliefs in mathematical problem solving: A path analysis. Journal of Educational Psychology, 86, 193-203.

Pajares, F., Johnson, M.J., \& Usher, E.L. (2007). Sources of writing self-efficacy beliefs of elementary, middle, and high school students. Research in the Teaching of English, 42(1), 104-120.

Pajares, F., \& Valiante, G. (2006). Self-efficacy beliefs and motivation in writing development. In C. MacArthur, S. Graham, \& J. Fitzgerald (Eds.), Handbook of writing research (pp. 158-170). New York: Guilford Press.

Podell, D. M., \& Soodak, L.C. (1993). Teacher efficacy and bias in special education referrals. Journal of Educational Research, 86, 247-253.

Putman, S. M. (2012). Investigating teacher efficacy: Comparing preservice and inservice teachers with different levels of experience. Action in Teacher Education, 34, 26-40. 
Rapp, J. R. (2009). The “write” tools: The impact of teachers' self-efficacy on classroom writing instruction. (Doctoral dissertation). Retrieved from ProQuest Dissertations and Theses. (3389806).

Riggs, I., \& Enochs, L. (1990). Toward the development of an elementary teacher's science teaching efficacy belief instrument. Science Education, 74, 625-637.

Rose, J. S., \& Medway, F. J. (1981). Measurement of teachers' beliefs in their control over student outcomes. Journal of Educational Research, 74, 185-190.

Ross, J.A. (1994). The impact of an inservice to promote cooperative learning on the stability of teacher efficacy. Teaching \& Teacher Education, 10(4), 381-394.

Rotter, J. R. (1966). Generalized expectancies for internal versus external control of reinforcement. Psychological Monographs, 80, 1-28.

Routman, R. (2005). Writing essentials: Raising expectations and results while simplifying teaching. Portsmouth, NH: Heinemann..

Salkind, N. J. (2011). Statistics for people who (think they) hate statistics. Thousand Oaks, CA: Sage.

Schunk, D. H. (1991). Self-efficacy and academic motivation. Educational Psychologist, 26, 207-231.

Shaughnessy, M. F. (2004). An interview with Anita Woolfolk: The educational psychology of teacher efficacy. Educational Psychology Review, 16(2), 153-176.

Shell, D.F., Murphy, C. C., \& Bruning, R. H. (1989). Self-efficacy and outcome expectancy mechanisms in reading and writing achievement. Journal of Educational Psychology, 81(1), 91-100.

Smagorinsky, P., \& Barnes, M. E. (2014). Revisiting and revising the apprenticeship of 
observation. Teacher Education Quarterly, 41(4), 29-52.

Soodak, L.C., \& Podell, D. M. (1996). Teacher efficacy: Toward the understanding of a multi-faceted construct. Teaching \& Teacher Education, 12(4), 401-411.

Street, B V. (1984). Literacy in theory and practice. Melbourne, Australia: Cambridge University Press.

Street, B. V. (1995). Social literacies: Critical approaches to literacy in development, ethnography and education. London: Longman.

Street, C., \& Stang, K. K. (2009). In what ways do teacher education courses change teachers' self confidence as writers? Teacher Education Quarterly, 36(3), 75-94.

Troia, G. A., Lin, S. C., Cohen, C., Monroe, B. W. (2011). A year in the writing workshop linking writing instruction practices and teachers' epistemologies and beliefs about writing instruction. The Elementary School Journal, 112(1), 155182.

Tschannen-Moran, M., \& McMaster, P. (2009). Sources of self-efficacy: Four professional development formats and their relationship to self-efficacy and the implementation of a new teaching strategy. The Elementary School Journal, 110(2), 228-245.

Tschannen-Moran, M., Woolfolk Hoy, A. (2007). The differential antecedents of selfefficacy beliefs of novice and experienced teachers. Teaching and Teacher Education, 23, 944-956.

Tschannen-Moran, M., Woolfolk Hoy, A. (2001). Teacher efficacy: Capturing an elusive construct. Teaching and Teacher Education, 17, 783-805. 
Tschannen-Moran, M., Woolfolk Hoy A., \& Hoy W. K. (1998). Teacher efficacy: Its meaning and measure. Review of Educational Research, 68(2), 202-248.

Usher, E. L., \& Pajares, F. (2008). Sources of self-efficacy in school: Critical review of the literature and future directions. Review of Educational Research, 78(4), 751796.

Wachholz, P.B., \& Etheridge, C. P. (1996). Writing self-efficacy beliefs of high - and low -apprehensive writers. Journal of Developmental Education, 19, 16-24.

Wood Ray, K. (1999). Wondrous words: Writers and writing in the elementary classroom. Urbana, IL: National Council of Teachers of English.

Zancanella, D. (1991). Techers reading/readers teaching: Five teachers' personal approaches to literature and their teaching of literature. Research in the Teaching of English, 25(1), 5-32.

Zimmerman, B. J. (2000). Self-efficacy: An essential motive to learn. Contemporary Educational Psychology, 25, 82-91.

Zimmerman, B. J., \& Bandura, A. (1994). Impact of Self-Regulatory Influence on Writing Course Attainment. American Educational Research Journal, 31(4), $845-862$.

Zumbrunn, S., \& Krause, K. (2012). Conversations with leaders: Principles of effective writing instruction. The Reading Teacher, 65(5), 346-353 
APPENDIX A

INFORMED CONSENT FORM 
W-WestViriginiaUniversity:
Human Research Protocol Only Minimal Risk Consent Form Without HIPAA

\section{Only Minimal Risk Consent Information Form (without HIPAA)}

Principal Investigator

Department

Protocol Number

Study Title

Co-Investigator(s)
Dr. Malayna Bernstein

Curriculum and Instruction, College of Education and Human Services

1705604538

Understanding Teachers' Self-Efficacy in the Teaching of Writing

Barbara Wierzbicki

Contact Persons

If you have any questions, concerns, or complaints about this research, you can contact Barbara Wierzbicki at 304-680-1058 or Dr. Malayna Bernstein at 304-293-3202.

For information regarding your rights as a research subject, to discuss problems, concerns, or suggestions related to the research, to obtain information or offer input about the research, contact the Office of Research Integrity and Compliance (304) 293-7073.

In addition if you would like to discuss problems, concerns, have suggestions related to research, or would like to offer input about the research, contact the Office of Research Integrity and Compliance at 304-293-7073.

\section{Introduction}

You, , have been asked to participate in this research study, which has been explained to you by Barbara Wierzbicki. This study is being conducted by Barbara Wierzbicki and Dr. Malayna Bernstein in the Department of Curriculum and Instruction at West Virginia University.

This research is being conducted to fulfill the requirements for Mrs. Wierzbicki's doctoral dissertation in Education in the Department of Curriculum and Instruction/Literacy Studies at West Virginia University, under the supervision of Dr. Malayna Bernstein.

Purpose(s) of the Study

The purpose of this study is to learn more about how teachers' sense of efficacy manifests itself in the teaching of writing. It is a case study of elementary school teachers.

\section{Description of Procedures}

This study involves two separate interviews, each of which will take about one hour. The interviews will
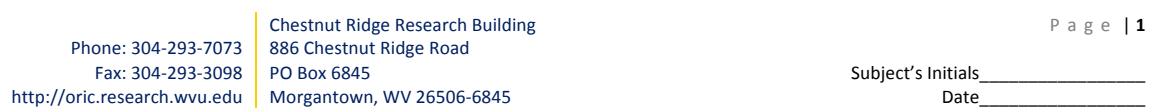


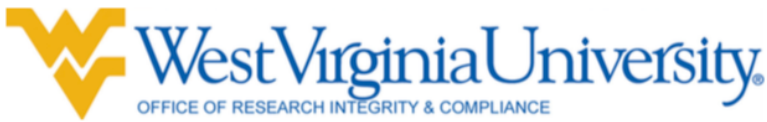

\author{
Human Research Protocol \\ Only Minimal Risk Consent Form \\ Without HIPAA
}

be conducted at a time and place of your choosing that is convenient for you. Once the time and place has been decided upon, I will meet you there. At any time during the interviews, you can stop answering questions in the interview, take a break, skip a question, or ask to resume at a later time.

The first interview will be a narrative interview, for which I will ask you to remember and describe writing- and teaching-related events from throughout your life. This interview will be audio-recorded and later transcribed

The second interview is a think-aloud interview. Mrs. Wierzbicki will provide you with a writing standard (from the Common Core State Standards for your grade level) and ask you to design a lesson plan that would help students meet the standard. As you develop the plan, Mrs. Wierzbicki will occasionally stop you and ask you to explain certain choices. This interview will be audio- and video-recorded. The video will only capture the lesson plan itself, along with your hands and arms as you write. The camera will be focusing on the written work, not on you. The audio-recording from this interview will be transcribed, and still shots from the video will be inserted into the transcript to help the investigators understand your descriptions.

\section{Risks and Discomforts}

There are no known or expected risks to you from participating in this study, except for the mild frustration associated with answering questions.

\section{Benefits}

You may not receive any direct benefits from this study. The knowledge gained from this study may expand the knowledge of teachers' sense of efficacy in the context of teaching writing.

\section{Financial Considerations}

There are no special fees for participating in this study.

Upon completion of the online survey and the two interviews, you will receive a $\$ 25.00$ gift card to Amazon. If you choose to withdrawal before the end of the study, no payment will be made.

\section{Confidentiality}

Any information about you that is obtained as a result of your participation in this research will be kept as confidential as legally possible.

All audio and video data will be stored on a password-protected computer, and upon completion of transcription, all audio and video recordings will be destroyed. All transcriptions will also be stored on a password-protected computer. In any publications that result from this work, neither your name nor any information from which you might be identified will be published.

Voluntary Participation

Participation in this study is voluntary. You are free to withdraw your consent to participate in this study

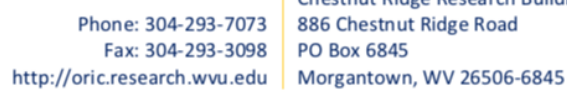

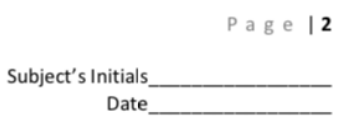




\section{WestVirginiaUniversity.}

Human Research Protocol

Only Minimal Risk Consent Form

Without HIPAA

at any time. Refusal to participate or withdraw will not affect you in any way.

You have been given the opportunity to ask questions about the research, and you have received answers concerning areas you did not understand.

\section{Activities}

I willingly consent to the following activities:

Being Interviewed

Being audio-recorded

Being video-recorded

Upon signing this form, you will receive a copy.

I willingly consent to participate in this research.

\section{Signatures}

$\begin{array}{lll}\text { Signature of the Subject } & \text { Date } & \text { Time }\end{array}$

Printed Name

Date

Time

The participant has had the opportunity to have questions addressed. The participant willingly agrees to be in the study.

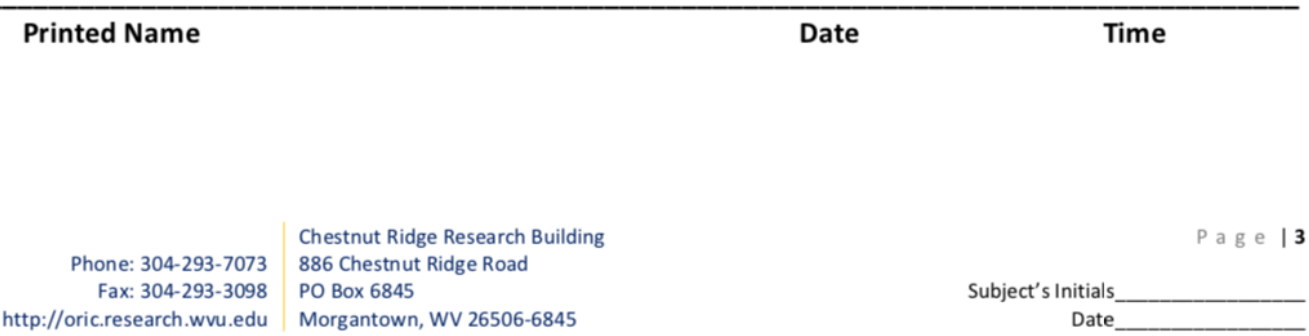


APPENDIX B BACKGROUND INFORMATION 


\section{Background Information}

1. Please circle your gender: male female

2. Please circle your highest educational level:

Bachelor's Bachelor's plus Master's Master's plus Doctorate

3. What certifications do you currently hold?

4. How many years have you taught (including this year)?

5. What grade(s) do you currently teach?

5. How many years have you taught at your current grade?

6. Please circle your evaluation of the quality of the preparation you received for teaching writing within your teacher certification program.

Exceptional Very Good Adequate Poor Inadequate

8. How much preparation in teaching writing have you received outside of college (e.g., assistance from another teacher, in-service preparation, and so forth)?

None Minimal Adequate Extensive

9. Please describe your feelings about your writing experiences:

10. Please describe your feelings about teaching writing: 
APPENDIX C

NEW GENERAL SELF-EFFICACY SCALE (NGSES)

(CHEN, GULLY, \& EDEN, 2001) 


\section{New General Self-Efficacy Scale (NGSES) \\ (Chen, Gully, \& Eden, 2001)}

Please indicate the degree to which you agree or disagree with each statement below by circling the appropriate number under each statement. Responses range from:

$$
\begin{aligned}
& 1 \text { - Strongly Disagree } \\
& 2 \text { - Disagree } \\
& 3 \text { - Neutral } \\
& 4 \text { - Agree } \\
& 5 \text { - Strongly Agree }
\end{aligned}
$$

1. I will be able to achieve most of the goals that I have set for myself.
1
2
3
4
5

2. When facing difficult tasks, I am certain that I will accomplish them.
1
2
3
4
5

3. In general, I think that I can obtain outcomes that are important to me.

$\begin{array}{lllll}1 & 2 & 3 & 4 & 5\end{array}$

4. I believe I can succeed at most any endeavor to which I set my mind.
1 2 3
4
5

5. I will be able to successfully overcome many challenges.

$\begin{array}{lllll}1 & 2 & 3 & 4 & 5\end{array}$

6. I am confident that I can perform effectively on many different tasks.
1
2
3
4
5

7. Compared to other people, I can do most tasks very well.
1
2
3
4
5

8. Even when things are tough, I can perform quite well. 
APPENDIX D

SELF-EFFICACY FOR WRITING SCALE (SEWS) (BRUNING, DEMPSEY, KAUFFMAN, MCKIM, \& ZUMBRUNN, 2013) 


\section{Self-Efficacy for Writing Scale (SEWS)}

(Bruning, Dempsey, Kauffman, McKim, \& Zumbrunn, 2013)

Directions: On a scale from 0 (no chance) to 100 (completely certain), please rate how confident you are that you can perform each of the writing skills below. There are no right or wrong answers.

\begin{tabular}{|c|c|c|c|c|c|c|}
\hline U & 20 & $30 \quad 40$ & 50 & 6070 & 80 & 100 \\
\hline No & Very Little & Little & $50 / 50$ & Good & Very Good & Complete \\
\hline hance & Chance & Chance & Chance & Chance & Chance & Certainty \\
\hline
\end{tabular}

\section{Confidence About Writing}

1. I can think of many ideas for writing.

2. I can put my ideas into writing.

3. I can think of many words to describe my ideas.

4. I can think of a lot of original ideas.

5. I know exactly where to place my ideas in my writing.

6. I can spell my words correctly

7. I can write complete sentences.

8. I can punctuate my sentences correctly.

9. I can write grammatically correct sentences.

10. I can begin my paragraphs in the right spots.

11. I can focus on my writing for at least one hour.

12. I can avoid distractions while I write.

13. I can start writing assignments quickly.

14. I can control my frustrations when I write.

15. I can think of my writing goals before I write.

16. I can keep writing even when it's difficult. 
APPENDIX E

TEACHERS' SENSE OF EFFICACY SCALE (SHORT FORM) (TSES) (TSCHANNEN-MORAN \& WOOLFOLK-HOY, 2001) 


\section{Teachers' Sense of Efficacy Scale (short form) (TSES) (Tschannen-Moran \& Woolfolk-Hoy, 2001)}

Directions: This questionnaire is designed to help us gain a better understanding of the kinds of things that create difficulties for teachers in their school activities. Please indicate your opinion about each of the statements below. Your answers are confidential.

How much can you do?

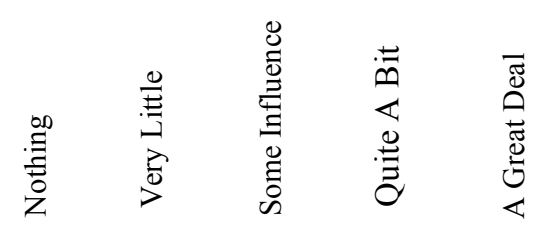

1. How much can you do to control disruptive behavior in the classroom?

(1) (2) (3) (4) (5) (6) (7) (8) (9)

2. How much can you do to motivate students who show low interest in school work?

(1) (2) (3) (4) (5) (6) (7) (8) (9)

3. How much can you do to get students to believe they can do well in school work?

(1) (2) (3) (4) (5) (6) (7) (8) (9)

4. How much can you do to help your students value learning?

(1) (2) (3) (4) (5) (6) (7) (8) (9)

5. To what extent can you craft good questions for your students?

(1) (2) (3) (4) (5) (6) (7) (8) (9)

6. How much can you do to get children to follow classroom rules?

(1) (2) (3) (4) (5) (6) (7) (8) (9)

7. How much can you do to calm a student who is disruptive or noisy?

(1) (2) (3) (4) (5) (6) (7) (8) (9)

8. How well can you establish a classroom management system with each group of students?

(1) (2) (3) (4) (5) (6) (7) (8) (9)

9. How much can you use a variety of assessment strategies?

(1) (2) (3) (4) (5) (6) (7) (8) (9)

10. To what extent can you provide an alternative explanation or example when students are confused?

(1) (2) (3) (4) (5) (6) (7) (8) (9)

11. How much can you assist families in helping their children do well in school?

(1) (2) (3) (4) (5) (6) (7) (8) (9)

12. How well can you implement alternative strategies in your classroom?

(1) (2) (3) (4) (5) (6) (7) (8) (9) 
APPENDIX F

TEACHER EFFICACY SCALE FOR WRITING (TESW)

(GRAHAM, HARRIS, FINK, \& MACARTHUR, 2001) 
Teacher Efficacy Scale for Writing (TESW)

(Graham, Harris, Fink, \& MacArthur, 2001)

Directions: Below are a series of statements. There are no right or wrong answers to these statements. Please indicate the degree to which you agree with each statement below by marking whether you: (1) strongly disagree; (2) moderately disagree; (3) disagree slightly more than agree; (4) agree slightly more than disagree; (5) moderately agree; or (6) strongly agree.

1. When students' writing performance improves, it is usually because I found better ways of teaching that student.

2. Even a good writing teacher may not reach many students.

3. If a student did not remember what I taught in a previous writing lesson, I would know how to increase his/her retention in the next lesson.

4. The hours in my class have little influence on students' writing performance compared to the influence of their home environments.

5. If a student masters a new writing concept quickly, this is because I knew the necessary steps in teaching this concept.

6. If I try really hard, I can help students with the most difficult writing problems.

7. When a student does better than usual in writing, it is because I exerted a little extra effort.

8. If students are not disciplined at home, they are not likely to accept any discipline during the writing period.

9. When a student is having difficulty with a writing assignment, I would have no trouble adjusting it to his/her level.

10. The influence of a student's home experience on writing can be overcome by good teaching.

11. A teacher is very limited in what he/she can achieve because a student's home environment is a large influence on his/her writing achievement.

12. If one of my students could not do a writing assignment, I would be able to accurately assess whether the assignment was at the correct level of difficulty.

13. The amount a student can learn in writing is primarily related to family background.

14. If a student becomes disruptive and noisy during writing time, I feel assured that I know some techniques to redirect him/her quickly.

15. When students' writing performance improves, it is usually because I found more effective teaching approaches.

16. If parents would do more in writing with their children, I could do more. 
APPENDIX G

NARRATIVE INTERVIEW PROTOCOL 


\section{Narrative Interview Protocol}

Introduction to the participant: Thank you for taking the time to talk with me today. I will be audio recording and then transcribing, verbatim, what we say. This discussion will probably take about an hour to complete.

1. Tell me about yourself as a writer. What should I know about you?

A. Can you tell me about a memorable (successful and/or challenging) writing experience (in or out of school).

B. During this experience, describe how confident you felt in your ability as a writer.

C. How would you describe your feelings and emotions during this experience?

2. What four words come to mind when you think of writing?

A. Why do you associate that word with writing?

3. How would you describe your overall feelings and emotions about your writing experiences?

4. Tell me about yourself as a teacher of writing. What should I know about you?

A. Can you tell me about a memorable experience you had teaching writing?

B. During this experience, describe how confident you felt in your ability to teach writing.

C. How would you describe your feelings and emotions during this experience?

5. What four words come to mind when you think of teaching writing?

A. Why do you associate that word with teaching writing?

6. How would you describe your overall feelings and emotions about teaching writing?

7. During this past school year, can you tell me about a writing lesson that you felt was particularly successful.

8. During this past school year, can you tell me about a writing lesson that you felt was particularly challenging?

9. How do you think, potentially, your previous experiences writing has affected the ways in which you teach writing?

10. Is there anything you would like to add about your experiences with writing or teaching writing?

Closure: I would like to thank you for your participation. Please know that the information you have shared with me is confidential. No part of our discussion will include names or other identifying information. Finally, I want to provide you with the opportunity to ask any questions that you might have about this research. 
APPENDIX H

DESCRIPTIVE STATISTICS CALCULATIONS 
The formula to convert the scores to $z$-scores is as follows:

where

$$
\frac{z=(X-\bar{X})}{s}
$$

$z$ is the $z$ score

$X$ is the individual score

$\bar{X}$ is the mean of the distribution

$s$ is the distribution standard deviation

\section{Calculation for Subscales: Sum, Mean, and Standard Deviation}

Self-Efficacy for Writing Scale (SEWS)

\begin{tabular}{|c|c|c|c|}
\hline & $\begin{array}{c}\text { Conventions } \\
\text { Sum }\end{array}$ & $\begin{array}{c}\text { Conventions } \\
\text { Mean }\end{array}$ & $\begin{array}{c}\text { Conventions } \\
\text { Standard Deviation }\end{array}$ \\
\hline Patsy & 450 & 90 & 0 \\
\hline Daisy & 350 & 70 & 11 \\
\hline Calvin & 490 & 98 & 4 \\
\hline Bella & 420 & 84 & 12 \\
\hline Eliza & 480 & 96 & 4.9 \\
\hline
\end{tabular}

\begin{tabular}{|c|c|c|c|}
\hline & $\begin{array}{c}\text { Ideation } \\
\text { Sum }\end{array}$ & $\begin{array}{c}\text { Ideation } \\
\text { Mean }\end{array}$ & $\begin{array}{c}\text { Ideation Standard } \\
\text { Deviation }\end{array}$ \\
\hline Patsy & 270 & 54 & 4.9 \\
\hline Daisy & 210 & 45.1 & 5.1 \\
\hline Calvin & 420 & 84 & 8 \\
\hline Bella & 360 & 72 & 7.5 \\
\hline Eliza & 430 & 86 & 10.2 \\
\hline
\end{tabular}

\begin{tabular}{|c|c|c|c|}
\hline & $\begin{array}{c}\text { Self-Regulation } \\
\text { Sum }\end{array}$ & $\begin{array}{c}\text { Self-Regulation } \\
\text { Mean }\end{array}$ & $\begin{array}{c}\text { Self-Regulation } \\
\text { Standard Deviation }\end{array}$ \\
\hline Patsy & 300 & 50 & 0 \\
\hline Daisy & 160 & 26.7 & 7.5 \\
\hline Calvin & 470 & 78.3 & 6.9 \\
\hline Bella & 290 & 48.3 & 6.9 \\
\hline Eliza & 440 & 73.3 & 7.5 \\
\hline
\end{tabular}


Teachers' Sense of Self-Efficacy Scale (TSES)

\begin{tabular}{|c|c|c|c|}
\hline & $\begin{array}{c}\text { Classroom Management } \\
\text { Sum }\end{array}$ & $\begin{array}{c}\text { Classroom Management } \\
\text { Mean }\end{array}$ & $\begin{array}{c}\text { Classroom Management } \\
\text { Standard Deviation }\end{array}$ \\
\hline Patsy & 32 & 8.0 & 0.7 \\
\hline Daisy & 27 & 6.8 & 0.8 \\
\hline Calvin & 31 & 7.8 & 0.8 \\
\hline Bella & 32 & 8.0 & 1.3 \\
\hline Eliza & 29 & 7.3 & 0.8 \\
\hline
\end{tabular}

\begin{tabular}{|c|c|c|c|}
\hline & $\begin{array}{c}\text { Student Engagement } \\
\text { Sum }\end{array}$ & $\begin{array}{c}\text { Student Engagement } \\
\text { Mean }\end{array}$ & $\begin{array}{c}\text { Student Engagement } \\
\text { Standard Deviation }\end{array}$ \\
\hline Patsy & 28 & 7.0 & 0.7 \\
\hline Daisy & 25 & 6.3 & 0.4 \\
\hline Calvin & 30 & 7.5 & 0.5 \\
\hline Bella & 32 & 8.0 & 1.2 \\
\hline Eliza & 27 & 6.8 & 0.8 \\
\hline
\end{tabular}

\begin{tabular}{|c|c|c|c|}
\hline & $\begin{array}{c}\text { Instructional Strategies } \\
\text { Sum }\end{array}$ & $\begin{array}{c}\text { Instructional Strategies } \\
\text { Mean }\end{array}$ & $\begin{array}{c}\text { Instructional Strategies } \\
\text { Standard Deviation }\end{array}$ \\
\hline Patsy & 33 & 8.3 & 0.4 \\
\hline Daisy & 22 & 5.5 & 0.5 \\
\hline Calvin & 29 & 7.3 & 0.4 \\
\hline Bella & 32 & 8.0 & 0.7 \\
\hline Eliza & 24 & 6.0 & 1.6 \\
\hline
\end{tabular}

Teacher Efficacy Scale for Writing (TESW)

\begin{tabular}{|c|c|c|c|}
\hline & $\begin{array}{c}\text { Personal Teaching Efficacy } \\
\text { Sum }\end{array}$ & $\begin{array}{c}\text { Personal Teaching Efficacy } \\
\text { Mean }\end{array}$ & $\begin{array}{c}\text { Personal Teaching Efficacy } \\
\text { Standard Deviation }\end{array}$ \\
\hline Patsy & 45 & 4.5 & 1.3 \\
\hline Daisy & 40 & 4.0 & 0.9 \\
\hline Calvin & 44 & 4.4 & 0.5 \\
\hline Bella & 32 & 8.0 & 1.2 \\
\hline Eliza & 27 & 6.8 & 0.8 \\
\hline
\end{tabular}

\begin{tabular}{|c|c|c|c|}
\hline & $\begin{array}{c}\text { General Teaching Efficacy } \\
\text { Sum }\end{array}$ & $\begin{array}{c}\text { General Teaching Efficacy } \\
\text { Mean }\end{array}$ & $\begin{array}{c}\text { General Teaching Efficacy } \\
\text { Standard Deviation }\end{array}$ \\
\hline Patsy & 19 & 3.2 & 1.1 \\
\hline Daisy & 26 & 4.3 & 1.1 \\
\hline Calvin & 30 & 5.0 & 1.0 \\
\hline Bella & 28 & 4.7 & 0.5 \\
\hline Eliza & 25 & 4.2 & 1.1 \\
\hline
\end{tabular}


APPENDIX I

SOURCES OF SELF-EFFICACY AS A WRITER 


\begin{tabular}{|c|c|c|}
\hline Theme & Definition & Example \\
\hline $\begin{array}{l}\text { Mastery Experiences as a } \\
\text { Writer }\end{array}$ & $\begin{array}{l}\text { Performance accomplishments based on an } \\
\text { individual's perceptions of their successes } \\
\text { or failures (Bandura, 1997) }\end{array}$ & $\begin{array}{l}\text { "Just the thought that you're putting } \\
\text { something down that wasn't there } \\
\text { before but because it's writing it's still } \\
\text { an idea and you're plucking a thought } \\
\text { out of your head and you're like putting } \\
\text { it out there for other people to see so } \\
\text { that's incredibly satisfying" (Eliza). }\end{array}$ \\
\hline $\begin{array}{l}\text { Positive Mastery } \\
\text { Experience }\end{array}$ & $\begin{array}{l}\text { The perception of those experiences that } \\
\text { have been successful as a writer. } \\
\text { Perception that a performance has been } \\
\text { successful raises efficacy beliefs } \\
\text { (Tschannen-Moran, et al., 1998). }\end{array}$ & $\begin{array}{l}\text { "I was the editor for the high school } \\
\text { newspaper and... it just was always so } \\
\text { easy" (Bella). }\end{array}$ \\
\hline $\begin{array}{l}\text { Negative Mastery } \\
\text { Experience }\end{array}$ & $\begin{array}{l}\text { The perception of those experiences that } \\
\text { have been challenging as a writer. } \\
\text { Perception that a performance has been a } \\
\text { failure lowers efficacy beliefs (Tschannen- } \\
\text { Moran, et al., 1998) }\end{array}$ & $\begin{array}{l}\text { "At the time when I was doing it and } \\
\text { realized that I had to get rid of all of } \\
\text { those pages it was something that I was } \\
\text { pretty upset about because...I had } \\
\text { written all of that... that was tough. To } \\
\text { go back through and figure out, out of } \\
\text { everything you have just written what is } \\
\text { the most important and what, what can I } \\
\text { take out? I feel like if it wasn't } \\
\text { important I wouldn't have written it in } \\
\text { there' (Calvin). }\end{array}$ \\
\hline $\begin{array}{l}\text { In School Mastery } \\
\text { Experience }\end{array}$ & $\begin{array}{l}\text { Experiences that occurred in an in-school } \\
\text { setting. }\end{array}$ & $\begin{array}{l}\text { "A challenging one was a reading class } \\
\text { at WVU. I had to do a case study on a } \\
\text { student that I was tutoring. It was } \\
\text { challenging for me to get all the } \\
\text { information that needed to be included } \\
\text { organized so that it was a professional } \\
\text { document. I tutored a student for one } \\
\text { semester and then had to prepare the } \\
\text { report not only for a grade but for the } \\
\text { parent as well" (Daisy). }\end{array}$ \\
\hline $\begin{array}{l}\text { Out of School Mastery } \\
\text { Experience }\end{array}$ & $\begin{array}{l}\text { Experiences that occurred in an out of } \\
\text { school setting. }\end{array}$ & $\begin{array}{l}\text { "I had this notebook that me and two } \\
\text { other friends passed around in middle } \\
\text { school and um.... we all had our own } \\
\text { characters and we would take turns } \\
\text { writing like a paragraph or sentence of } \\
\text { something our character did in the story. } \\
\text { And so... um... we were all in Girl } \\
\text { Scouts together so we had just... um.... } \\
\text { we were in this like campground or } \\
\text { whatever and um.... we snuck out of our } \\
\text { cabin and we went outside and um.... } \\
\text { we started writing together" (Eliza). }\end{array}$ \\
\hline $\begin{array}{l}\text { Verbal Persuasion as a } \\
\text { Writer }\end{array}$ & $\begin{array}{l}\text { Messages that an individual gets from } \\
\text { others that offers information about the } \\
\text { individual's capabilities as a writer. } \\
\text { "People who are persuaded verbally that } \\
\text { they possess the capabilities to master } \\
\text { given tasks are likely to mobile greater } \\
\text { effort and sustain it than if they harbor self- }\end{array}$ & $\begin{array}{l}\text { "His written feedback definitely helped } \\
\text { me grow as a writer. (Bella). }\end{array}$ \\
\hline
\end{tabular}




\begin{tabular}{|c|c|c|}
\hline & $\begin{array}{l}\text { doubts and dwell on personal deficiencies } \\
\text { when difficulties arise" (Bandura, 1997, p. } \\
\text { 101). }\end{array}$ & \\
\hline Positive Verbal Persuasion & $\begin{array}{l}\text { Comments that bolster an individual's self- } \\
\text { efficacy as a writer. }\end{array}$ & $\begin{array}{l}\text { "I wrote this story about like this } \\
\text { dolphin or it was like about this picture } \\
\text { of a dolphin that I saw and she said that } \\
\text { my descriptions were so gorgeous she } \\
\text { could see the dolphin and feel the } \\
\text { dolphin or whatever and that was I think } \\
\text { the first time I considered myself to be a } \\
\text { good writer" (Eliza). }\end{array}$ \\
\hline Negative Verbal Persuasion & $\begin{array}{l}\text { Comments that inhibit an individual's self- } \\
\text { efficacy as a writer. }\end{array}$ & $\begin{array}{l}\text { "In college, I had to write papers and } \\
\text { that was always a struggle for me and I } \\
\text { always just assumed I would not get a } \\
\text { good grade on the writing. I remember it } \\
\text { took forever and then when the paper } \\
\text { was returned it had red ink comments } \\
\text { everywhere.... which I think made me } \\
\text { hate writing and feel like a failure" } \\
\text { (Daisy) }\end{array}$ \\
\hline In School Verbal Persuasion & $\begin{array}{l}\text { Comments that an individual received in a } \\
\text { school setting. }\end{array}$ & $\begin{array}{l}\text { "I think it was my instructor because she } \\
\text { took the time to explain how to develop } \\
\text { a well-written paper. She was kind in } \\
\text { her feedback, not judgmental, and it was } \\
\text { constructive.... like how to improve my } \\
\text { writing (Patsy). }\end{array}$ \\
\hline $\begin{array}{l}\text { Out of School Verbal } \\
\text { Persuasion }\end{array}$ & $\begin{array}{l}\text { Comments that an individual received in an } \\
\text { out of school setting. }\end{array}$ & $\begin{array}{l}\text { "When I was in kindergarten, my } \\
\text { mom...like I dictated while my mom } \\
\text { wrote so um I think that was really nice } \\
\text { um and I think that probably gave me a } \\
\text { little bit more confidence like even } \\
\text { though I couldn't write as a } \\
\text { kindergartener I was giving the } \\
\text { sentences to someone and my sentences } \\
\text { were still being written down so I think } \\
\text { that was a nice thing um and then like } \\
\text { whenever I wrote a story like whenever } \\
\text { I wrote a story I knew that I could go to } \\
\text { my parents and give it to them and then } \\
\text { they would like my mom would always } \\
\text { say you know like she would always } \\
\text { give a lot of positive feedback...my dad } \\
\text { was a little bit more balanced with um } \\
\text { the constructive criticisms um...but I } \\
\text { could always give my writing to my } \\
\text { parents so I think my parents had a huge } \\
\text { hand in encouraging my enthusiasm but } \\
\text { I....still think that probably came from } \\
\text { me...probably...yeah" (Eliza). }\end{array}$ \\
\hline
\end{tabular}




\begin{tabular}{|c|c|c|}
\hline $\begin{array}{l}\text { Physiological (Affective) } \\
\text { State as a Writer }\end{array}$ & $\begin{array}{l}\text { Somatic indicators of personal efficacy } \\
\text { (Bandura, 1997)." It is not the sheer } \\
\text { intensity of emotional and physical } \\
\text { reactions that is important but rather how } \\
\text { they are perceived and interpreted" } \\
\text { (Bandura, 1994, p. 73). }\end{array}$ & $\begin{array}{l}\text { "It [writing] is not something that scares } \\
\text { me. I mean it is kind of easy for me to } \\
\text { just sit down and write" (Calvin). } \\
\text { "It was very stressful because I felt like } \\
\text { I was in over my head. I was afraid my } \\
\text { writing was not good enough and that } \\
\text { was terrifying" (Patsy). }\end{array}$ \\
\hline Positive Feeling & Feelings of excitement and joy as a writer & $\begin{array}{l}\text { "I was just feeling the joy of writing...I } \\
\text { felt as though I was in a safe place...I } \\
\text { was doing something incredibly } \\
\text { enjoyable" (Eliza). }\end{array}$ \\
\hline Negative Feeling & $\begin{array}{l}\text { Feelings of stress, anxiety, pressure, and } \\
\text { tension as a writer. }\end{array}$ & $\begin{array}{l}\text { "I was feeling very anxious. I wanted } \\
\text { my writing to sound...let me } \\
\text { think...eloquent" (Daisy). }\end{array}$ \\
\hline In School Experience & $\begin{array}{l}\text { Experiences that occurred in an in-school } \\
\text { setting. }\end{array}$ & $\begin{array}{l}\text { "It [writing] was something I felt very } \\
\text { confident with...um...I struggled in } \\
\text { math a good bit so it was like it } \\
\text { [writing] gave me that outlet. I felt as } \\
\text { though I was good at something ... when } \\
\text { I struggled with another subject I would } \\
\text { feel good knowing that I was good at } \\
\text { writing" (Bella) }\end{array}$ \\
\hline Out of School Experience & $\begin{array}{l}\text { Experiences that occurred in an out of } \\
\text { school setting. }\end{array}$ & $\begin{array}{l}\text { "For like } 30 \text { minutes or an hour or } \\
\text { something we [Girl Scouts] were out } \\
\text { there just writing and singing together. } \\
\text { That shared writing was just magic...It } \\
\text { felt amazing! I felt connected to others. } \\
\text { I felt like I was living vicariously } \\
\text { through my characters...It felt like it } \\
\text { was just flowing out of me" (Eliza) }\end{array}$ \\
\hline
\end{tabular}

*Theoretically driven themes are cited with references. Data driven themes are defined in my own words. 
APPENDIX J

SOURCES OF SELF-EFFICACY AS A TEACHER OF WRITING 


\begin{tabular}{|c|c|c|}
\hline Theme & Definition & Example \\
\hline $\begin{array}{l}\text { Mastery Experiences as a } \\
\text { Teacher of Writing }\end{array}$ & $\begin{array}{l}\text { Performance accomplishments based on } \\
\text { an individual's perceptions of their } \\
\text { successes or failures as a teacher of } \\
\text { writing }\end{array}$ & $\begin{array}{l}\text { "I put up a creative writing prompt or } \\
\text { like an opinion writing prompt or } \\
\text { something and the kids just had to write } \\
\text { for seven minutes and then we had like } \\
\text { three minutes or so of sharing and } \\
\text { um... and during that time I would walk } \\
\text { around the room and I kind of bent over } \\
\text { kids shoulders and like commented on } \\
\text { what they were doing and like if they } \\
\text { wanted to read something to me they } \\
\text { could. If they wanted to check spelling } \\
\text { with me they could and that was really } \\
\text { nice because it was just so cool because } \\
\text { pretty much to a tee every kid was just } \\
\text { super engaged in what they were doing" } \\
\text { (Eliza) }\end{array}$ \\
\hline Positive Mastery Experiences & $\begin{array}{l}\text { The perception of those experiences that } \\
\text { have been successful as a teacher of } \\
\text { writing. }\end{array}$ & $\begin{array}{l}\text { "So last year I brought math writing into } \\
\text { our math class and it became a station. It } \\
\text { was the first time I had done it...I don't } \\
\text { think that I realized that that was } \\
\text { something that was missing in my math } \\
\text { class before, until I like did it and } \\
\text { realized that writing isn't just about } \\
\text { like... what happens in reading class or } \\
\text { writing class and that they [students] } \\
\text { need to learn how to write across the } \\
\text { curriculum. It was really eye opening to } \\
\text { see how they wrote about math..." } \\
\text { (Calvin). }\end{array}$ \\
\hline Negative Mastery Experiences & $\begin{array}{l}\text { The perception of those experiences that } \\
\text { have been negative as a teacher of } \\
\text { writing. }\end{array}$ & $\begin{array}{l}\text { "We [students] were not getting } \\
\text { paragraphs at all. Um...I just hit a brick } \\
\text { wall...I could not get across to them } \\
\text { what a paragraph was" (Bella). }\end{array}$ \\
\hline $\begin{array}{l}\text { Verbal Persuasion as a } \\
\text { Teacher of Writing }\end{array}$ & $\begin{array}{l}\text { Messages that an individual gets from } \\
\text { others that offers information about the } \\
\text { individual's self-efficacy as a teacher of } \\
\text { writing. } \\
\text { "People who are persuaded verbally that } \\
\text { they possess the capabilities to master } \\
\text { given tasks are likely to mobile greater } \\
\text { effort and sustain it than if they harbor } \\
\text { self-doubts and dwell on personal } \\
\text { deficiencies when difficulties arise" } \\
\text { (Bandura, 1997, p. 101). }\end{array}$ & $\begin{array}{l}\text { "To Eliza the best writing teacher ever. } \\
\text { Thanks for your inspiration." It was } \\
\text { amazing!! and she like handed this to } \\
\text { me um...you know right before winter } \\
\text { break and it was all rolled up and } \\
\text { everything and she was like, "Ms. } \\
\text { Buras, Here... My parents and I went to } \\
\text { an art show and the guy was there and it } \\
\text { was like...my gosh! That was probably } \\
\text { one of the most amazing experiences of } \\
\text { my first year. That was my first-year } \\
\text { teaching (Eliza)! }\end{array}$ \\
\hline Positive Comments & $\begin{array}{l}\text { Those comments that bolster an } \\
\text { individual's self-efficacy as a teacher of } \\
\text { writing. }\end{array}$ & $\begin{array}{l}\text { "To Eliza the best writing teacher ever. } \\
\text { Thanks for your inspiration." It was } \\
\text { amazing!! and she like handed this to }\end{array}$ \\
\hline
\end{tabular}




\begin{tabular}{|c|c|c|}
\hline & & $\begin{array}{l}\text { me um...you know right before winter } \\
\text { break and it was all rolled up and } \\
\text { everything and she was like, "Ms. } \\
\text { Buras, Here... My parents and I went to } \\
\text { an art show and the guy was there and it } \\
\text { was like...my gosh! That was probably } \\
\text { one of the most amazing experiences of } \\
\text { my first year. That was my first-year } \\
\text { teaching (Eliza)! }\end{array}$ \\
\hline Negative Comments & $\begin{array}{l}\text { Those comments that inhibit an } \\
\text { individual's self-efficacy as a teacher of } \\
\text { writing. }\end{array}$ & $\begin{array}{l}\text { "Well, I would have to say by their } \\
\text { actions. When it is time for writing, I } \\
\text { hear...." Oh, no, not already" or "oh no } \\
\text { not again"! I also hear my kids say, "I } \\
\text { hate writing. It is boring." I also hear } \\
\text { "This is hard! I can't think of anything } \\
\text { to write" (Daisy). }\end{array}$ \\
\hline $\begin{array}{l}\text { Physiological (Affective) State } \\
\text { as a Teacher of Writing }\end{array}$ & $\begin{array}{l}\text { Somatic indicators of personal efficacy } \\
\text { (Bandura, 1997) as a teacher of writing. } \\
\text { "It is not the sheer intensity of emotional } \\
\text { and physical reactions that is important } \\
\text { but rather how they are perceived and } \\
\text { interpreted" (Bandura, 1994, p. 73). }\end{array}$ & $\begin{array}{l}\text { "I need to remember that I love writing } \\
\text { but remember that a lot went into me } \\
\text { learning how to love writing and me } \\
\text { learning how to grow as a writer" } \\
\text { (Eliza). } \\
\text { "It [teaching writing] is kind of scary..." } \\
\text { (Daisy) }\end{array}$ \\
\hline Positive Feeling & $\begin{array}{l}\text { Those feelings of excitement and joy as a } \\
\text { teacher of writing. }\end{array}$ & $\begin{array}{l}\text { "I would have to say rewarding and } \\
\text { even exciting, especially when I have } \\
\text { students who want to share with me } \\
\text { what they have written...there is a } \\
\text { sparkle in their eyes and a smile on their } \\
\text { faces. This make me feel good as well" } \\
\text { (Patsy). }\end{array}$ \\
\hline Negative Feeling & $\begin{array}{l}\text { Those feelings of stress, anxiety, } \\
\text { pressure, and tension as a teacher of } \\
\text { writing. }\end{array}$ & $\begin{array}{l}\text { "This is where it gets a little difficult } \\
\text { because teaching writing, for me, wasn't } \\
\text { the easiest thing to do when I started and } \\
\text { I think it was because I was so confident } \\
\text { with my own writing ability...It's } \\
\text { [teaching writing] hard!... It's hard to } \\
\text { take what you are thinking and put it on } \\
\text { paper" (Calvin). }\end{array}$ \\
\hline
\end{tabular}

*Theoretically driven themes are cited with references. Data driven themes are defined in my own words. 
APPENDIX K NUMBER CHART OF CODED SOURCES OF EFFICACY INFORMATION 


\begin{tabular}{|c|c|c|c|c|c|c|}
\hline Theme & Patsy & Daisy & Calvin & Bella & Eliza & $\begin{array}{c}\text { Total Number } \\
\text { of } \\
\text { References }\end{array}$ \\
\hline Mastery Experiences as a Writer & 0 & 2 & 8 & 4 & 6 & 20 \\
\hline Positive Experiences & 0 & 0 & 3 & 4 & 6 & 13 \\
\hline Negative Experiences & 0 & 2 & 5 & 0 & 0 & 7 \\
\hline In School Experiences & 0 & 2 & 1 & 4 & 1 & 8 \\
\hline Out of School Experiences & 0 & 0 & 7 & 0 & 5 & 12 \\
\hline $\begin{array}{l}\text { Mastery Experiences as a } \\
\text { Teacher of Writing }\end{array}$ & 3 & 3 & 5 & 4 & 6 & 21 \\
\hline Positive Experiences & 2 & 2 & 3 & 3 & 5 & 15 \\
\hline Negative Experiences & 1 & 1 & 2 & 1 & 1 & 6 \\
\hline Verbal Persuasion as a Writer & 1 & 2 & 3 & 6 & 4 & 16 \\
\hline Positive Experiences & 1 & 1 & 3 & 2 & 3 & 10 \\
\hline Negative Experiences & 0 & 1 & 0 & 4 & 1 & 6 \\
\hline In School Experiences & 1 & 2 & 2 & 6 & 3 & 14 \\
\hline Out of School Experiences & 0 & 0 & 1 & 0 & 1 & 2 \\
\hline $\begin{array}{c}\text { Verbal Persuasion as a Teacher } \\
\text { of Writing }\end{array}$ & 0 & 1 & 0 & 0 & 1 & 2 \\
\hline Positive Experiences & 0 & 0 & 0 & 0 & 1 & 1 \\
\hline Negative Experiences & 0 & 1 & 0 & 0 & 0 & 1 \\
\hline $\begin{array}{l}\text { Physiological Arousal as a } \\
\text { Writer }\end{array}$ & 10 & 4 & 9 & 5 & 13 & 41 \\
\hline Positive Experiences & 0 & 0 & 7 & 4 & 11 & 22 \\
\hline Negative Experiences & 10 & 4 & 2 & 1 & 2 & 19 \\
\hline In School Experiences & 8 & 3 & 4 & 5 & 2 & 22 \\
\hline Out of School Experiences & 2 & 1 & 5 & 0 & 11 & 19 \\
\hline $\begin{array}{c}\text { Physiological Arousal as a } \\
\text { Teacher of Writing } \\
\end{array}$ & 6 & 6 & 10 & 14 & 14 & 50 \\
\hline Positive Experiences & 5 & 2 & 4 & 5 & 8 & 24 \\
\hline Negative Experiences & 1 & 4 & 6 & 9 & 6 & 26 \\
\hline
\end{tabular}

